\title{
CEO COMPENSATION STRUCTURE AND FIRM PERFORMANCE
}

\author{
Anna Pedersen Wright
}

A thesis submitted in fulfilment of the requirements for the degree of Doctor of Philosophy

2005

School of Accounting

The University of Technology, Sydney 


\section{CERTIFICATE OF AUTHORSHIP / ORIGINALITY}

I certify that the work in this thesis has not previously been submitted for a degree, nor has it been submitted as part of requirements for a degree, except as fully acknowledged within the text.

I also certify that the thesis has been written by me. Any help that I have received in my research work and the preparation of the thesis itself has been acknowledged. In addition, I certify that all information sources and literature used are indicated in the thesis.

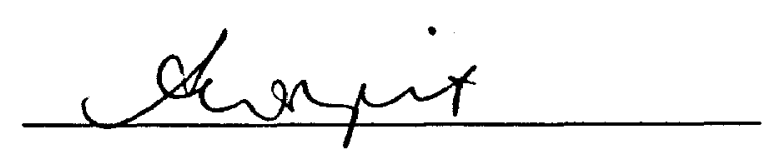

Anna Wright 


\section{ACKNOWLEDGEMENTS}

This thesis was supervised by Professor Zoltan Matolcsy and Professor Donald Stokes, to whom I am greatly indebted for their knowledge, patience and support throughout this process.

Many people provided helpful discussions, comments and insights on different aspects of this thesis, and in particular I would like to thank Bruce Bennett, Mike Bradbury, Robert Bushman, Dan Dhaliwal, SP Kothari, Stephen Penman, Terry Shevlin, Dan Simunic, Stephen Taylor, Sue Wright and the participants in the research seminars at UTS, Monash University, Unitec and Macquarie University.

From the School of Accounting, the comments, support and friendship of my colleagues is greatly appreciated, and in particular I would like to thank Judy Dousha, Judy Evans, Jon Tyler, and Peter Wells.

I would also like to thank Colin Wright for his detailed and careful proof reading and editing of the thesis.

Financial support from the School of Accounting by way of $\mathrm{PhD}$ Scholarship and research assistance is gratefully acknowledged, as to is the support provided by Accenture.

Finally, thanks goes to my family, without whom this thesis would never have been possible, nor would have been worth the journey. 


\section{TABLE OF CONTENTS}

$\begin{array}{ll}\text { Chapter } & \text { Page }\end{array}$

1 Introduction 1

2 Australian CEO Compensation: The Descriptive Evidence 11

2.1 Introduction 11

$2.2 \quad$ Literature Review 15

2.2.1 Descriptive evidence from the United States 15

$\begin{array}{lll}\text { 2.2.2 Descriptive evidence from Australia } & 17\end{array}$

$\begin{array}{lll}\text { 2.2.3 Australian professional survey evidence } & 18\end{array}$

2.2.4 Differences observed to date between Australia and the United States 20

2.3 Sample Selection 22

$2.4 \quad$ Key Descriptive Results 24

2.4.1 Overall Sample Characteristics 24

2.4.2 Compensation characteristics by industry and group 30

2.4.3 Level of CEO Compensation and Firm Characteristics - Appendix 2.B 40

2.4.4 Option grant characteristics 43

2.5 Implications of Findings 46 
3 The Relation between Firm Characteristics and CEO

Compensation Structure $\quad 48$

3.1 Introduction 48

$3.2 \quad$ Literature Review 52

3.3 Theory Development - The Economic Determinants of Compensation Structure $\quad 55$

$3.4 \quad$ Sample and Data 61

3.4.1 Sample selection 61

3.4.2 Research Design 61

3.4.3 Firm characteristics and different types of equitybased compensation $\quad 63$

3.5 Results 63

3.5.1 Descriptive and Univariate results 63

3.5.2 Firm characteristics and different types of equitybased compensation $\quad 67$

3.5.2.1 Exercise price types and firm characteristics $\quad 68$

3.5.2.2 Option term types and firm characteristics 71

3.5.2.3 Option hurdles and firm characteristics 75

$3.6 \quad$ Implications of Findings 77 
4 The Relation between CEO Compensation Structure and Firm Performance $\quad 79$

$\begin{array}{lll}4.1 & \text { Introduction } & 79\end{array}$

$4.2 \quad$ Literature Review 85

4.2.1 Evidence using changes in compensation and changes in performance $\quad 85$

4.2.2 Evidence using levels of compensation and performance

4.2.3 Evidence on the relation between different components of compensation and firm performance

4.2.4 Evidence on efficient contracting theory and firm performance 91

4.2.5 Australian evidence 92

4.2.6 Limitations in the literature to date 94

4.3 Theory Development 97

4.3.1 The use of equity-based compensation to improve firm performance $\quad 98$

4.3.2 Firm characteristics and compensation structure $\quad 100$

4.4 Research Design 104

4.4.1 Hypothesis One: Compensation Structure and Firm Performance 104

4.4.1.1 Sample and data 104

4.4.1.2 Experimental design 104

4.4.1.3 Other tests - the relation between firm performance and different types of equitybased compensation

4.4.2 Hypothesis Two: Efficient Compensation

Structures and Firm Performance 
4.4.2.1 Sample and data 106

4.4.2.2 Experimental design 107

4.4.2.2.1 The first stage - the benchmark compensation contract

4.4.2.2.2 The second stage - deviations from the predicted compensation structure $\quad 110$

$\begin{array}{lll}4.5 & \text { Results } & 110\end{array}$

$\begin{array}{lll}\text { 4.5.1 Hypothesis One } & 110\end{array}$

4.5.1.1 Other tests - the structure of equity awards and firm performance

4.5.2 Hypothesis Two: Efficient compensation structures and firm performance

4.5.2.1 First stage - predicted group membership

4.5.2.2 Second stage - predicted group

membership and firm performance

4.6 Implications of Findings 
Appendix 1.A The "UTS-Accenture Who Governs Australia"

Database - Data Dictionary

Appendix 2.A The Valuation of Executive and Employee Stock

Options

Appendix 2.B Firm Characteristics and the Level of CEO

Compensation

Appendix 2.C Option Grant Characteristics Across Industry Groups

Appendix 2.D Combination of Option Grant Characteristics across each Option Grant

Appendix 2.E Option Grant Characteristics of Firms Making Multiple Option Grants

Appendix 3.A Compensation Group and Firm Characteristics by Industry

Appendix 4.A The Structure of Option Awards and Firm

Performance 


\section{LIST OF TABLES}

Table Title

Page

Number

$2.1 \quad$ Sample Selection

2.2 Distribution of Firms across the Two Compensation

Groups 25

2.3 Number and percentage of Firm-years using each

reported Compensation Component 28

2.4 Percentage of Firms using Each Compensation Contract

by Industry $\quad 30$

2.5A Compensation Characteristics by Compensation Group -

Mining Industry

2.5B Compensation Characteristics by Compensation Group -

$\begin{array}{ll}\text { Manufacturing Industry } & 34\end{array}$

2.5C Compensation Characteristics by Compensation Group -

Banking and Finance Industry

2.5A Compensation Characteristics by Compensation Group -

Other Industry 36

2.6 Option Grant Characteristics 43

3.1 Economic characteristics of the firm important to

compensation structure

3.2 Sample distribution and statistical differences across

groups, total sample 
3.4 Firm characteristics and option terms

3.5 Firm characteristics and option hurdles

4.2 Economic characteristics of the firm that determine CEO compensation structure

4.3 Descriptive statistics - performance of firms, total sample

4.4 Summary of the OLS regression coefficients for the relation between firm performance, group membership and performance controls

4.5 Descriptive statistics - performance of firms on the adjusted ROA measure, total sample

4.6 Descriptive results for the ex ante economic characteristics of firms in the 1999 year

4.7 Summary of the Legit regression coefficients for the relation between compensation group membership and underlying firm characteristics

4.8 Comparison between the results in this Chapter to United States' results

4.9 Classification Table 
Table Title

Number

4.10 Performance results of firms in the predicted group vs.

those that are not

4.11 Summary of the OLS regression coefficients for the relation between firm performance, correct/incorrect group membership and performance controls

2.B.1 Economic characteristics of the firm that determine the level of CEO compensation

2.B.2 Descriptive results

2.B.3a Descriptive results for the independent variables of the Mining industry by compensation group

2.B.3b Descriptive results for the independent variables of the Manufacturing industry by compensation group

2.B.3c Descriptive results for the independent variables of the Banking and Finance industry by compensation group

2.B.3d Descriptive results for the independent variables of the Other industry by compensation group

2.B.4 Correlations between firm characteristics and total compensation

2.B.5 Correlations between firm characteristics and the components of total compensation 
Table Title

Number

2.B.6 Summary of the OLS Regression coefficients for the relation between total compensation and underlying firm characteristics 172

2.B.7 Comparison between the results in this Appendix to the United States' results in Core, Holthausen and Larcker (1999) (CHL)

2.B.8 Summary of the OLS Regression coefficients for the relation between total compensation and the underlying firm characteristics using the Core, Holthausen and Larcker (1999) proxies for firm size

2.B.9 Summary of the OLS Regression coefficients for the relation between total compensation and the underlying firm characteristics by industry and compensation group

2.D.1 Combination of Option Grant Characteristics across each

Option Grant

2.E.1 Option Grant Characteristics of Firms making Multiple Option Grants

3.A.1 Sample distribution and statistical differences across groups, Mining Industry

3.A.2 Sample distribution and statistical differences across groups, Manufacturing Industry 
Table Title

Page

Number

3.A.3 Sample distribution and statistical differences across

groups, Banking and Finance Industry

198

3.A.4 Sample distribution and statistical differences across

groups, Other Industry

4.A.1 Descriptive statistics - performance of option granting firms, total sample

4.A.2a Descriptive statistics - performance of option granting firms, by option term

4.A.2.b Performance and option terms

4.A.3a Descriptive statistics - performance of option granting firms, by exercise price type

4.A.3b Performance and exercise prices

4.A.4a Descriptive statistics - performance of option granting firms, by hurdles

4.A.4b Performance and hurdles

4.A.5 Summary of the OLS Regression coefficients for the relation between firm performance, option characteristics and performance controls 


\section{LIST OF GRAPHS}

Graph

Title

Page

Number

2.1A Level and Composition of Total CEO Compensation by

Industry and Compensation Group - Mining Industry

2.1B Level and Composition of Total CEO Compensation by

Industry and Compensation Group - Manufacturing Industry

2.1C Level and Composition of Total CEO Compensation by

Industry and Compensation Group - Banking and Finance

Industry

2.1D Level and Composition of Total CEO Compensation by

Industry and Compensation Group - Other Industry

$\begin{array}{lll}\text { 2.C.1 Exercise Prices across Industry } & 185\end{array}$

2.C.2 Option Terms across Industry 186

$\begin{array}{lll}2 . C .3 & \text { Option Hurdles across Industry } & 187\end{array}$ 


\section{$\underline{\text { ABSTRACT }}$}

Many academic studies investigate CEO compensation practices [Murphy (1999)], and the subject is also widely discussed in the popular press. However, the academic literature to date has concentrated on settings where CEOs are typically offered equitybased compensation, and these equity awards are relatively similar in terms of characteristics. To date, CEO compensation practices have not been investigated in a setting where firms in similar industries concurrently use either cash only or cash and equity to compensate their CEOs, and where the characteristics of the equity grants also differ across firms. This thesis researches CEO compensation in such a setting.

The objective of this thesis is to provide evidence on the use and performance consequences of different CEO compensation structures. Specifically, the thesis first determines whether the use of the different compensation structures is linked to different firm characteristics. Second, the thesis examines the relation between firm performance and the use of the different compensation structures, and third, the thesis investigates the performance consequences of deviations from an estimated "efficient" compensation structure.

Using large Australian firms reporting in the 1999 to 2001 financial years, Chapter Two provides descriptive evidence on the variation observed in Australian CEO compensation structures, and finds that around one-third of large Australian firms offer their CEO only cash based compensation, while the remaining two-thirds use some level 
of equity-based compensation. Chapter Three provides some explanation for the observed variation by demonstrating that firms using the different compensation structures have significantly different economic characteristics. Chapter Four examines the performance consequences of compensation structure choice. This Chapter first finds little evidence of systematic differences in firm performance across the two compensation structures. Then this Chapter models an "efficient" compensation structure based on firm characteristics, and tests the performance consequences of deviations from this efficient structure. Chapter Four finds some (although weak) evidence that firms using an inefficient structure have lower firm performance compared to firms using an efficient structure.

This thesis makes contributions to the literature in number of areas. First, the thesis shows that it could be efficient for firms with different economic characteristics to use different compensation structures. Second, the thesis finds that firm performance is not necessarily related to the use of one or other of the different compensation structures, but rather that lower firm performance is a consequence of incorrect compensation structure choice. Overall, this thesis provides important new insights into the use of different CEO compensation structures. 


\section{CHAPTER 1}

\section{INTRODUCTION}

The amount of research into chief executive officer (CEO) compensation practices has grown dramatically during the past two decades [Murphy (1999)]. However, the evidence in this literature is based solely on settings where CEO compensation structures are relatively homogeneous across firms, and CEOs are typically offered some level of equity-based compensation. Further, the structure of these equity awards is also relatively similar in terms of the exercise prices, life of the grant and the use of performance hurdles. To date, issues relating to CEO compensation have not been addressed in a setting where CEO compensation structures are not homogeneous. That is, these issues have not been addressed in a setting where firms in similar industries concurrently use cash only or cash and equity to compensate their CEOs and where equity grants differ across firms. This thesis researches a number of issues relating to CEO compensation in such a setting, thus providing new evidence on compensation structure possibilities.

The objective of this thesis is to provide evidence on the use and performance consequences of different CEO compensation structures. Specifically, this thesis first examines the links between the economic characteristics of the firm and the use of the different compensation structures (that is, cash only versus cash plus equity structures). Second, the thesis examines the performance consequences of the use of the different 
compensation structures, and third, the thesis examines the performance consequences of deviations from the "correct" compensation structure.

There are two motivations for the thesis. First, theoretical literature suggests that differences in firm characteristics could lead to differences in CEO compensation structure [Demsetz and Lehn (1985), Smith and Watts (1992), Gaver and Gaver (1993), Core, Holthausen and Larcker (1999)] and that it can be efficient for some firms not to award equity-based compensation [Bushman and Smith (2001)]. However, to date the literature has not explored differences in CEO compensation structures as it has concentrated on settings where homogeneous compensation structures are used. This thesis provides the first evidence on the links between firm characteristics and the use of different compensation structures, as well as whether or not different compensation structures are associated with differences in firm performance.

Second, both Australian regulators and investors have expressed interest in CEO compensation practices, in particular the levels of CEO compensation and the link between CEO compensation and firm performance [for example, The Sydney Morning Herald "Business News" September 18/19 2004 p25 onwards, discussing the 2004 compensation reporting etc]. Much of the debate concentrates on the levels of compensation awarded to the CEO, and expresses cynicism in whether the level of CEO compensation is related to increases in firm performance. For example, Allan Fels writes in the Financial Review "CEO compensation levels are growing at a rate out of step with the value they are actually providing to their employers, the shareholders. 
Millions of dollars of shareholders' funds are being wasted"1. These opinion pieces provide little or no evidence to support their arguments, and despite this, there has been very little investigation by the academic community into Australian CEO compensation practices. Cursory evidence on firm characteristics and levels and structures of CEO compensation is provided by Crease, Goodwin and Kent (2001) and Coulton and Taylor (2002a), and limited evidence on the pay-performance relation is found in Defina, Harris and Ramsay (1994), Izan, Sidhu and Taylor (1998) and Matolcsy (2000), while there has been no investigation into the relation between firm performance and compensation structure. This thesis provides the first detailed evidence on the levels and structure of Australian CEO compensation, and indicates that on average, CEO compensation (both levels and structure) is linked to the underlying characteristics of the firm. This suggests that on average, firms could be offering their CEOs reasonable compensation levels and structures. Further, while the popular press has not appeared as interested in the CEOs' compensation structure, this thesis demonstrates that firm performance could suffer when the incorrect compensation structure is awarded. Thus this thesis provides regulators and investors with information that could assist with their respective legislative and investment decisions.

The evidence presented in this thesis is based on large Australian firms using firms reporting in the 1999 to 2001 financial years, following the introduction of new compensation disclosure requirements. Prior to 1 July 1998, director compensation disclosure requirements were contained in AASB 1017 "Related Party Transactions"

\footnotetext{
'Financial Review, 10 February 2004, article 10, page 54.
} 
and executive compensation disclosure requirements were contained in AASB 1034 "Financial Report Presentation and Disclosures". The required compensation disclosure comprised bandwidth counts of the number of executives receiving compensation within $\$ 10,000$ bands, beginning at $\$ 100,000$, and bandwidth counts of all directors' compensation, again within $\$ 10,000$ bands, beginning at $\$ 0$. Total directors' compensation was also provided, along with total compensation paid to all executives receiving more than $\$ 100,000^{2}$, and only summarised information was provided on the conditions of the equity-based compensation awarded to executives and directors ${ }^{3}$.

On 1 July 1998, part of the Australian Government's Corporate Law Economic Reform Program, the Company Law Review Act of 1998, came into effect and applied to all companies with financial years ending on or after 1 July 1998. This Act ${ }^{4}$ requires all companies from 1 July 1998 to provide much greater detail as to the compensation paid to all directors and the five most highly paid executives of the company. Specifically, companies must include in their annual report a discussion as to how the nature and amount of compensation is determined for the directors and top five executives, a discussion as to the relation between the company's compensation policy and firm performance, and details as to the nature and amount of each element of the compensation received by each director and top executive by individual.

\footnotetext{
${ }^{2}$ These disclosure requirements were introduced in 1986, and were contained in Clause 25, Schedule 5 of the Corporations Regulations, AASB 1017 and AASB 1034.

3 The details provided included the total options issued, the date of the grant, the exercise period and exercise price. In order to obtain the names of the holders of the options, the company's register had to be inspected. This limited disclosure was available under the ASC class order 94/284.

Specifically contained in sections $300 \mathrm{~A}$ and 300 (1)(d).
} 
While CEO and management compensation details are now available in Australian annual financial reports, these figures must be hand collected. In order to facilitate both this thesis and future research, the "UTS-Accenture Who Governs Australia" database was developed to house corporate governance data in electronic form. Starting in January 2001, the shell of the Access database was built by Accenture over three months, and data was hand collected over the following two years by the author. The data dictionary for the database is summarised in Appendix 1.A, and further details are available from the University of Technology, Sydney, School of Accounting.

Chapter Two provides descriptive evidence on Australian compensation practices (both levels and structure), and also compares these Australian results to those found in the United States by Murphy (1999) and Core, Holthausen and Larcker (1999). When investigating levels of compensation, Chapter Two finds that the level of Australian CEO compensation is linked to the underlying economic characteristics of the firm. Specifically, the Chapter finds that the level of compensation is significantly positively related to firm size, complexity and current market performance, and more weakly positively related to growth options, prior market performance and current accounting performance. Comparing these results to those found in the United States by Core, Holthausen and Larcker (1999) suggests that while there is some similarity between Australia and the United States in the way in which the level of CEO compensation is decided, there are also some significant differences. 
Further, when investigating compensation structure, Chapter Two also finds significant variation in compensation practices in Australia compared to the United States. Around one-third of the largest Australian firms offer their CEO only cash based compensation [the cash group], while the remaining two-thirds use some level of equity-based compensation [the equity group]. The cash group firms offer no equity-based compensation at all, nor do they have any provisions in place to offer equity-based compensation. Chapter Two also reports this variation across the industry groups.

Chapter Two also finds variation within the equity group, where different types of equity grants are made across and within firms. The variation in option grants includes variation in the exercise prices used ${ }^{5}$, the option term ${ }^{6}$, and in the use of performance hurdles ${ }^{7}$. This variation is significantly different to the option grants observed in the United States' market [as described in Murphy (1999)], where options tend to be uniformly issued at fair market value, have 10 year terms and no performance hurdles attached. Again, this variation in option grants is observed across all industry groups.

This thesis provides some explanation for the variation in the compensation structure in Chapters Three and Four. The objective of Chapter Three is to provide evidence on the links between underlying firm characteristics and the use of different CEO compensation structures. Specifically, Chapter Three investigates whether or not firms

\footnotetext{
${ }^{3}$ Fair market value (exercise price at market on date of issue), premium (exercise price greater than market at date of issue) and discount (exercise price less than market at date of issue) options are all observed.

With terms from 1 year to greater than 10 years observed.

${ }^{7}$ Performance hurdles are used by some firms while others do not use them.
} 
with different compensation structures have different economic characteristics. This question has not been addressed in the literature to date, as the research has concentrated on the empirical relation between firm characteristics and the amount of equity-based compensation awarded to the CEO. Chapter Three also explores the relation between firm characteristics and the use of different types of equity granted to the CEO, again a question not addressed in the literature to date.

Chapter Three provides evidence that firms in the different compensation groups have significantly different economic characteristics. Cash group firms compared to the equity group firms are smaller, are less decentralised, have lower growth options but have higher CEO share ownership. These findings are consistent with the extant theoretical literature.

Chapter Four examines performance consequences of compensation structure choice for the equity and cash groups of firms in two ways. First, the Chapter determines whether there are any systematic differences in firm performance across the two compensation structure groups. Second, the Chapter models an "efficient" compensation structure based on firm characteristics, identifies the firms deviating from this contract, and tests the performance consequences of the deviation. Again, these questions have not been examined in the literature to date.

When investigating the systematic differences in performance across the two compensation structure groups, there are two possible alternative expectations of the 
link between compensation structure and firm performance. On one hand, many studies have argued that management's incentives are more closely aligned with those of shareholders when management receive some form of equity-based compensation [Holmstrom (1979), Harris and Raviv (1979), Grossman and Hart (1983), Smith and Watts (1982), Smith and Stultz (1985), Hirshleifer and Suh (1992) and Shleifer and Vishney (1997)]. If management's actions are more closely aligned with the use of equity-based compensation, then firm performance should be better in the firms that award equity-based compensation.

On the other hand, it has also been argued that compensation structure should be set dependent on the underlying economic characteristics of the firm [Demsetz and Lehn (1985), Lambert and Larcker (1987), Banker and Datar (1989), Smith and Watts (1992), Gaver and Gaver (1993), Core, Holthausen and Larcker (1999), Datar, Kulp and Lambert (2001), Bushman and Smith (2001)], and these studies imply that it might not be efficient for all firms to provide equity-based compensation. If the compensation structures are efficient, there would be no cross-sectional differences in firm performance observed, on average [Core, Holthausen and Larcker (1999), Ittner, Lambert and Larcker (2003)]. Chapter Four finds little evidence of systematic differences in firm performance across the two groups, which indicates that the use of equity-based compensation is not necessarily linked to greater firm performance.

To investigate the second objective of Chapter Four testing the performance consequences of deviations from the "efficient" compensation structure, a model is 
estimated that attempts to describe the efficient compensation structure based on theorised firm characteristics. Firms deviating from the predicted compensation structure are identified, and their performance is compared to those firms identified as using the "correct" compensation structure. The prediction for this section is that firms using inefficient CEO compensation structures could have lower firm performance compared to those that use an efficient structure [Ittner, Lambert and Larcker (2003)]. Chapter Four finds some (although weak) evidence that firms in the inefficient compensation group do have lower firm performance compared to firms in the efficient group.

Finally, Chapter Five provides a summary and conclusions and addresses the implications of the work for research and the public policy debate on CEO compensation.

This thesis makes contributions to the literature in several areas. First, the thesis explores a recent setting in which both cash only and cash plus equity-based compensation is used to compensate the CEO, and shows that the use of different compensation structures is linked to different underlying economic characteristics of the firm. Thus the thesis confirms the theory and expands on the existing research by demonstrating that it could be efficient for firms with different economic characteristics to use different compensation structures. The implication of this finding is that a "onesize-fits-all" model of CEO compensation structure might not be appropriate, even though it has been implied by some academic research that advocates for the use of 
equity-based compensation, such as Holmstrom (1979), Harris and Raviv (1979), Grossman and Hart (1983), Smith and Watts (1982), Smith and Stultz (1985), Hirshleifer and Suh (1992) and Shleifer and Vishney (1997).

Second, the thesis examines the performance consequences of the use of different compensation structures, and finds that on average, performance does not differ across compensation structure choice. Thus the results show that firm performance is not necessarily related to the use of one or the other of the different compensation structures. Consequently, the thesis provides evidence that the use of equity-based compensation is not necessarily linked to improved firm performance. These findings also imply that on average, firms appear to be making efficient compensation structure choices.

Third, the thesis models the "correct" compensation structure choice, and provides evidence that lower performance is a consequence of incorrect compensation structure choice. Further, these results indicate that while the majority of firms appear to be making the correct choice, there are a few firms making incorrect structure choices, and it is here that performance might be improved if compensation structure choice is aligned with firm characteristics. Overall, this thesis provides important new insights into the use of different CEO compensation structures. 


\section{CHAPTER 2}

\section{AUSTRALIAN CEO COMPENSATION: THE DESCRIPTIVE EVIDENCE}

\subsection{INTRODUCTION}

Academic research into CEO compensation structures and other practices to date has concentrated on a data set in which the CEO's compensation structure is reasonably homogeneous across firms. That is, the research has concentrated on a data set of United States' firms that typically offer some form and level of equity-based compensation to their CEOs ${ }^{1}$. Australia offers an interesting environment in which to study CEO compensation, in that not all firms offer equity-based compensation to their CEOs, and thus variation in CEO compensation structure is observed. This variation in compensation structure provides opportunities for research questions to be addressed that have not been previously investigated, such as the links between firm characteristics and the use of different types of compensation structures, and the performance consequences of the use of the different structures. However, despite this unique academic opportunity, as well as widespread attention from the Australian business community $^{2}$ and the Australian Federal Government ${ }^{3}$ to Australian CEO compensation

\footnotetext{
'Most compensation research to date had been conducted in the United States market, where little variation in compensation design is observed. Murphy (1999) states that most United States executive pay packages contain stock options as one of the four basic components of pay [page 2491]. Further, Murphy reports that during the $1990 \mathrm{~s}$, stock options became the single largest component of compensation in all industries but utilities, replacing base salary. Murphy cites Hall and Liebman (1998), who show that the use of option compensation has increased monotonically in the United States since the early $1990 \mathrm{~s}$. In contrast, anecdotal evidence suggests that stock options as a component of CEO compensation have not had the same importance in the Australian market. For example, this anecdotal evidence suggests that there are a number of firms in which there is no stock option plan approved, and consequently there is no possibility for these firms to grant stock options to their CEO at all. However, there is no detailed academic evidence available on Australian compensation practices.

2 For example see the detailed discussion in the Sydney Morning Herald 18/19 September 2004 starting on p45.

${ }^{3}$ For example, on $8^{\text {th }}$ August 2002, Prime Minister John Howard warned business leaders that the government would introduce tougher corporate governance regulation should current business practice not improve. Further, Mr Howard stated that one of the
} 
practices, there is very little detailed descriptive evidence available, with only limited and partial analysis using compensation proxies and small samples provided by Coulton and Taylor (2002a). The objective of this Chapter is to provide the first detailed descriptive evidence on Australian CEO compensation during the period 1999 to $2001^{4}$ (following the introduction of the new compensation disclosure requirements), along with a comparison between the Australian results and those for the United States as reported by Murphy (1999).

There are a number of motivations for this Chapter. The first motivation is to provide descriptive evidence on this new setting and to contrast it with overseas evidence. In doing so, this Chapter provides the first detailed evidence on Australian CEO compensation. Thus the Chapter provides evidence on compensation practices that do not necessarily include the provision of equity-based compensation.

The second motivation is that both Australian regulators and investors have indicated interest in management compensation practices. First, Australian regulators implemented legislation that requires greater detail of management compensation to be included in the annual financial statements, indicating an interest in greater transparency of management compensation details ${ }^{5}$. More recently, Corporate Law Economic Reform Program (CLERP) 9 was passed by both Houses of Parliament on 25 June 2004,

regulatory changes would be in respect of recovering "excessive" executive remuneration [Australian Financial Review, 7/8/02, page 1].

This period has been chosen as new disclosure requirements effective from 1 July 1998 provide detailed information on the levels of CEO compensation and on the compensation structure.

${ }^{5}$ These requirements are discussed in Chapter One 
which requires further compensation disclosures for listed companies. Also recently released are the "ASX Principles of Good Governance and Best Practice Recommendations", with Principle 9 covering corporate remuneration policy.

The third motivation is that management compensation has also been of greater interest to the popular policy debate. Recent controversy has been reported in the financial press over bonuses and other types of remuneration awarded to executives [see for example The Sydney Morning Herald "Business News" September 18 / 192004 p25 onwards, which discusses the 2004 reporting of executive compensation]. Following the collapse of HIH, the Australian Shareholders' Association chief Tony McLean was quoted in the Sun-Herald as saying "A debacle like HIH only reinforces the cynicism that exists among individual shareholders about corporate behaviour and accountability. And the biggest beef is about executive remuneration - these handsome rewards while a company is in decline. I think, for a really good chief executive, people would say $\$ 1$ million in base salary and another $\$ 1$ million in options is acceptable. But this business of $\$ 10$ million is just exorbitant. ${ }^{36}$ This Chapter provides the first extensive and detailed evidence on the compensation practices of the large Australian firms over a three year window, thus contributing to the current policy debate by providing input to regulators on the existing Australian CEO compensation practices.

The evidence of this Chapter is based on a sample of large Australian firms for the period 1999-2001, a total of 696 firm years. All accounting and compensation related 
data are available from the "UTS-Accenture Who Governs Australia" database, while stock price information is collected from SIRCA.

The Chapter first identifies and groups the firms in the sample on whether or not they have a provision in place to grant the CEO stock options, or any other type of equitybased compensation. Those firms with no provisions at all for any form of equity-based compensation are allocated to the cash group, while firms that do use equity-based compensation are allocated to the equity group. Then, detailed descriptive evidence is presented on the compensation practices of these two distinct types of compensation contract groups. Specifically, this Chapter provides evidence on both the levels and structure of CEO compensation, including information on the levels and percentages of the separately reported components of pay, across industry group and across the two types of compensation contract awarded. In addition, descriptive evidence on the characteristics of the option grants made is also provided. Finally, where appropriate, comparison to the United States' results provided by Murphy (1999) is included.

This Chapter makes a number of contributions to the literature. First, descriptive evidence on a new compensation contract setting is presented, and detailed analysis is made of the different CEO compensation structures, along with a comparison to Murphy's (1999) results. Second, the Chapter improves on the Australian evidence to date in two ways. First, a larger data set is used, giving a more detailed picture of the compensation received by the CEOs of our largest firms. Further, more analysis of the

\footnotetext{
'Quoted in the Sun-Herald, May 20, 2001, page 10.
} 
compensation awarded is conducted, such as industry-level analysis. Third, the compensation data is improved by taking into account the lagged nature of bonuses. Australian studies to date have included the total compensation paid in that year as the total compensation received for the year. However, many annual reports have stated that the bonus paid in the current year is in respect of the prior year's performance. Consequently, in order to measure the compensation received in respect of any particular year, this thesis uses the bonus reported in the following year, rather than the current year bonus. This is particularly important when firm performance is examined.

The remainder of the Chapter is organised as follows. Section 2.2 reviews the prior descriptive evidence on compensation practices both in Australia and the United States and Section 2.3 describes the data used in the Chapter. Section 2.4 reports the descriptive statistics and the conclusions of the Chapter are contained in section 2.5.

\subsection{LITERATURE REVIEW}

\subsubsection{Descriptive evidence from the United States}

Murphy (1999) provides descriptive evidence on CEO compensation contracts in the United States using compensation data for CEOs in the S\&P 500, the S\&P Mid-Cap 400 and the S\&P Small-Cap 600 from 1992 to 1996, as well as an additional 1,000 large companies in 1992 and survey information from 177 large companies in 1996. He investigates the levels and structures of CEO compensation, and states that the majority of CEO pay packages in the United States contain the same basic components - base 
salary, accounting-based bonus, stock options and long-term incentive plans (such as restricted stock plans or multi-year accounting-based bonuses).

Although Murphy (1999) finds little variation in compensation structure across firms, he reports that $\mathrm{CEO}$ compensation levels vary by industry, where CEOs in the electrical utilities earn the least, while CEOs in the financial services sector earn the most. Further, Murphy (1999) shows that the levels of compensation (in 1996 constant dollars) have increased substantially from 1992 to 1996 , and that this increase in compensation is due largely to increases in the number of stock options awarded? ${ }^{7}$ Murphy (1999) also provides evidence that larger firms pay their CEOs more, although the relation between CEO compensation and firm size has weakened over time. Finally, he gives some international descriptive comparisons by using the 1997 Towers Perrin reports, and finds that CEOs in the United States not only get paid more than CEOs elsewhere (both in terms of base salary and total compensation), they are also paid differently, receiving a higher fraction of their compensation in stock options compared to their international counterparts.

Using the largest 1,000 companies filing proxy statements between January and September 1993, Murphy (1999) describes the option granting practice of these firms during the 1992 fiscal year. Out of the 1,000 firms, 627 firms made 853 option grants to

\footnotetext{
7 These results are updated and confirmed in Jensen, Murphy and Wruck (2004)
} 
their CEOs in the 1992 year $^{8}$. He finds that there is little cross-sectional variation in the granting practice, with most options expiring in 10 years, and granted with an exercise price equal to the "fair market value" or stock price on the date of the grant. Out of the 853 option grants, $95 \%$ are at fair market value, while only $3 \%$ are at a discount, and $1 \%$ at a premium. There was one indexed option, and two with exercise prices that increased over time in a predetermined manner. Murphy (1999) also shows that $83 \%$ of the grants had ten year terms, $13 \%$ had terms less than ten years, while $4 \%$ had terms longer than the ten years. Finally, Murphy (1999) finds that only 2 firms included a performance hurdle with the option grant.

\subsubsection{Descriptive evidence from Australia}

Descriptive evidence on Australian compensation practices in the academic literature is very limited, with only Coulton and Taylor (2002a) providing some evidence. Their sample consists of 258 out of the 511 largest Australian firms included on the Connect 4 database for the 2000 financial year'. Coulton and Taylor (2002a) value the options awarded at $25 \%$ of exercise price, and find that the mean total CEO compensation for the total sample of 258 firms in the 2000 year is $\$ 1,061,433$, with salary comprising $45.4 \%(\$ 481,400)$, bonus $17.7 \%(\$ 188,071)$ other (such as fringe benefits) and

\footnotetext{
"Murphy (1999) only provides information on the 1992 options granted, consequently the option granting behaviour of the firms not granting options in the 1992 year is unknown. However, Murphy does report that out of the 373 firms not granting options to the CEO in the 1992 year, 120 made option grants to other executives in that year.

The primary exclusions from the sample were firms in the mining industry and investment trusts, firms reporting in foreign currency and firms with a CEO change in the 2000 year.
} 
superannuation $11.7 \%(\$ 123,869)$, and stock options $25.3 \%(\$ 268,093)^{10}$. However, Coulton and Taylor (2002a), only provide evidence for one year, and with no additional analysis such as industry distributions. Further, they use a $25 \%$ of exercise price proxy to measure stock option values, while the majority of the United States' literature uses the Black-Scholes valuation method.

\subsubsection{Australian professional survey evidence}

Limited descriptive evidence on Australian compensation practices can also be found in the professional survey literature. Towers Perrin release annual "Worldwide Total Remuneration" reports that cover a number of countries, including Australia and the United States. These reports are based on the Towers Perrin estimates of "typical pay", and are expressed in United States' dollars. Using the Reserve Bank year-end rates, average total Australian CEO remuneration is reported as $1997^{11} \$ 639,437,1998^{12}$ $\$ 703,977,1999^{13} \$ 786,528$, and $2000^{14} \$ 1,079,713$. The Towers Perrin reports also provide an indication as to the approximate structure of CEO pay in each of the years. The 1997 and 1998 reports show that Australian CEOs receive less than 1.5\% of their compensation in the form of long-term incentives, but receive around $17 \%$ in the form of variable bonus. The 1999 report documents a significant increase in long-term

\footnotetext{
${ }^{10}$ However, please note that these percentages differ from those reported in the tables of the Coulton and Taylor (2002a) paper, and have been calculated from the dollar values given in the same tables.

"Sample based on incustrial companies with around $\$$ US250 million in annual sales

${ }^{12}$ Based on a sample of industrial companies with around SUS250-5500 million in sales

${ }^{13}$ Based on a sample of industrial companies with around SUS500 million in annual sales

${ }^{14}$ Based on a sample of industrial companies with around $\$$ US 500 million per annum in sales
} 
incentives $^{15}$, with about $18 \%$ now paid, while the variable bonus portion dropped to $14 \%$ of total compensation. Finally, the 2000 report shows long-term incentives steady at $17 \%$ of compensation, while variable bonuses increased to $26.5 \%$.

The 1997 and 1998 Towers Perrin reports show a very low proportion of long-term incentives in Australian executive remuneration compared to that received by executives in the United States [1.5\% in Australia compared to $28 \%$ in the United States]. This low incidence of long-term incentives given in Australia has also been reported in other early surveys. The Hay Group (1991) survey finds that the most popular form of incentive pay in Australian firms is target-based compensation with a cash bonus. Cullen Egan Dell (1997) also find similar results, reporting that around $80 \%$ of the organisations they surveyed use short-term incentive plans, while $33 \%$ have long-term incentive plans.

Cullen Egan Dell (1997) also provide some descriptive evidence on Australian option plans. They find that only $41 \%$ of options plans have no performance hurdles in place, and that the most common hurdle used is earnings per share (EPS). Cullen Egan Dell (1997) also look at the exercise price of the options granted, and find that only $56 \%$ of plans have the exercise price set at fair market value, $28 \%$ having the price determined by the board of directors, $6 \%$ at a specific share price hurdle, $3 \%$ at a premium and $3 \%$ relative to a share market index ${ }^{16}$. Exercise data information is also given, with the most common time to exercise set at earliest 3 years from issue ( $60 \%$ of plans), 1 year in $30 \%$

\footnotetext{
15 What is included as "long-term incentives or compensation" is not disclosed in the reports

16 The remaining $4 \%$ stated as "other"
} 
of plans and 2 years in $10 \%$ of plans. Most plans (55\%) lapse after 5 years and $6 \%$ after 4 years. Murphy (1999) presents evidence that implies that option grants in the United States are relatively generic with exercise prices at fair market value ${ }^{17}$, option terms at 10 years and a lack of performance hurdles. This Cullen Egan Dell (1997) evidence on Australian option plans suggests that option grant characteristics in Australia are very different from those in the United States, in that much greater variation is observed. This Chapter provides more recent evidence on Australian option grant characteristics, and compares those practices to those reported by Murphy (1999).

\subsubsection{Differences observed to date between Australia and the United States}

The Towers Perrin reports also provide comparative descriptive evidence between the United States and Australia. For the years 1997 to 2000, the Towers Perrin reports rank the United States' CEOs as the highest paid in the world, with Australian CEOs receiving significantly less total remuneration. The reports also show that United States' CEOs also receive differently structured remuneration. However, the Towers Perrin reports are surveys of compensation consultants' beliefs of pay structures, rather than detailed evidence of existing practices. This Chapter provides evidence of the compensation structures of Australian CEOs based on the numbers provided in the audited financial statements.

\footnotetext{
${ }^{17}$ stock price on the date of the grant
} 
Comparisons between Murphy (1999) and Coulton and Taylor (2002a) also indicate differences between Australia and the United States in the way in which CEOs are compensated. While Murphy finds that in the 1992 year $63 \%$ of his sample made option grants to their CEOs (although he also states that most firms have an option plan in place), Coulton and Taylor (2002a) find that only $31 \%$ of their sample firms award options to their CEOs in the 2000 year ${ }^{18}$, indicating that option awards might not be as systematic in Australia as they are in the.United States.

Stock options also appear to be awarded differently in Australia compared to the United States. While Murphy (1999) finds that there is little cross-sectional variation in the granting practice in the United States, the Australian evidence presented by Cullen Egan Dell (1997) shows greater variation.

Overall the limited evidence to date on Australian CEO compensation practices indicates that those practices are different from those that occur in the United States. First, it appears that the use of equity-based compensation and stock options is more common in the United States than in Australia, where not all CEOs are awarded equitybased compensation as part of their compensation packages. Second, where firms do award options in Australia, those option awards appear far less generic than those observed in the United States, and are also smaller in value. As most of the academic evidence on CEO compensation practices comes from the United States' market, this evidence is on compensation packages that predominantly include equity-based

\footnotetext{
${ }^{18}$ However, Coulton and Taylor (2002a) do not indicate how many firms have an option scheme in place.
} 
compensation and relatively similar option grants. By studying the Australian market, this thesis provides important evidence on alternative practices. Specifically this Chapter provides descriptive evidence on the levels and structures of compensation offered to Australian CEOs, as well as evidence on the characteristics of the option grants made, and where possible, comparison between Australian and United States' practices is made.

\subsection{SAMPLE SELECTION}

The sample selection starts with all firms included in the "Top 500" Australian firms". (by market capitalisation) for the years 1999,2000 , and 2001. Deleted from the sample are investment trusts and managed funds, which are subject to different governance and reporting requirements. Also deleted from the sample are firms reporting in foreign currency, firms where management were paid by another company, firms with missing data $^{20}$, and firms listed during the year. Firms are also deleted from the sample where two years of prior data was not available, as at least two years of data is needed for the ex ante return variables. Finally, firms that changed their CEO during the year are excluded for that year only, as the outgoing CEO' compensation typically includes some type of separation payment which is not separately reported, while the incoming CEO typically receives some type of signing bonus, again not separately reported [Coulton and Taylor (2002a)]. The final sample comprised 227 firms for 1999, 224 firms for

\footnotetext{
19 As listed on Connect 4 (an electronic financial statement database of the top 500 Australian firms). Firms that drop out or join the Top 500 during the sample period are included in the analysis where they pass the sample requirements.

20 In that the data was not included in the annual report of the company, nor could be found in later annual reports, nor in information given to the shareholders at the annual general meetings.
} 
2000 and 245 firms for 2001 . Table 2.1 below summarises the sample selection

procedure:

TABLE 2.1 - SAMPLE SELECTION

\begin{tabular}{|l|r|r|r|r|}
\hline & \multicolumn{1}{|c|}{1999} & \multicolumn{1}{|c|}{2000} & \multicolumn{1}{c|}{ TOTAL } & \multicolumn{1}{|c|}{} \\
\hline Original Sample & 513 & 510 & 507 & 1,530 \\
Reason for deletion: & & & & \\
Investment trusts and managed & 77 & 69 & 55 & 201 \\
funds & 10 & 12 & 20 & 42 \\
Missing data & 12 & 14 & 13 & 39 \\
Management paid by another & 22 & 25 & 20 & 67 \\
firm & 1 & 23 & 30 & 54 \\
Foreign currency & 139 & 93 & 70 & 302 \\
Listed during year & 25 & 50 & 54 & 129 \\
Prior 2 years of data not & 227 & 224 & 245 & 696 \\
CEailable change & & & \\
Final sample & & & & \\
\hline
\end{tabular}

All CEO compensation and firm accounting data was hand collected ${ }^{22}$ by the author, and is stored in the "UTS-Accenture Who Governs Australia" database. Total CEO compensation is measured using the bonus paid in the year following (instead of the bonus paid in the current year) in order to control for the lagged nature of bonuses.

Options granted in the year are valued using the Black-Scholes formula, with adjustment

\footnotetext{
${ }^{21}$ Due to data deletions, only 121 firms appear in all three years.

${ }^{22} \mathrm{CEO}$ compensation data was hand collected by the author from the original annual reports and other information of Australian companies. First, the names of the CEOs were collected, along with the appropriate appointment and resignation dates. Next, the dollar amounts of each of the different forms of compensation received were taken from the Directors' Report and the Notes to the Accounts. Also collected were the details of the equity-based compensation grants so that Black-Scholes option values could be calculated, as well as the details in respect of any performance hurdles attached to the grants. Finally, details of the current CEO shareholdings for each year were collected. All of these details were sourced from the Directors" Report, the Notes to the Accounts, the Information to Shareholders section and where appropriate, from the Annual General Meeting information. While all of this compensation detail is now a mandatory requirement, not all firms were transparent in their disclosure, especially in regards to the equity-based compensation grant details. However, compensation information was able to be sourced for all but 3 firms in the sample.
} 
for dividends [Refer Appendix 2.A for a discussion on the theoretical issues of how to values options, and for the formula used to value the options].

\subsection{KEY DESCRIPTIVE RESULTS}

\subsubsection{Overall Sample Characteristics}

Firms in the total sample are divided into one of two compensation contract types firms that provide cash to the CEO, but have no equity-based compensation scheme in place ${ }^{23}$ (the "cash" group), and firms that provide cash and equity-based compensation to the $\mathrm{CEO}^{24}$, or firms that have an equity-based compensation scheme in place ${ }^{25}$ (the "equity" group). It is important to note that firms in the "equity" group did not necessarily grant options to their CEOs in each of the years in the sample period, they were only required to have an equity-based compensation scheme in place. The final sample distribution is contained in Table 2.2 below:

\footnotetext{
${ }^{23}$ Equity-based compensation schemes must be approved by the annual general meeting of shareholders. Firms were classified into the "cash" group where there had been no such scheme approved.

${ }^{24}$ There were no firms in the sample that only awarded equity-based compensation to their CEO.

${ }^{25}$ Firms were classified into the equity group if there was an equity-based compensation scheme in place as not all firms awarded the CEO equity-based compensation every year.
} 
TABLE 2.2 - Distribution OF FIRMS ACROSS THE Two COMPENSATION GROUPS

\begin{tabular}{|c|c|c|c|c|c|c|c|c|}
\hline & \multicolumn{2}{|c|}{1999} & \multicolumn{2}{|c|}{2000} & \multicolumn{2}{|c|}{2001} & \multicolumn{2}{|c|}{ Total } \\
\hline & $\begin{array}{l}\text { Number } \\
\text { of firms }\end{array}$ & $\begin{array}{c}\text { Number } \\
\text { of } \\
\text { grants }\end{array}$ & $\begin{array}{l}\text { Number } \\
\text { of firms }\end{array}$ & $\begin{array}{l}\text { Num } \\
\text { ber of } \\
\text { grants }\end{array}$ & $\begin{array}{l}\text { Number } \\
\text { of firms }\end{array}$ & $\begin{array}{c}\text { Number } \\
\text { of } \\
\text { grants }\end{array}$ & $\begin{array}{l}\text { Number } \\
\text { of firms }\end{array}$ & $\begin{array}{c}\text { Number } \\
\text { of } \\
\text { grants }\end{array}$ \\
\hline $\begin{array}{l}\text { Cash } \\
\text { group: }\end{array}$ & 77 & & 77 & & 84 & & 238 & \\
\hline $\begin{array}{l}\text { Equity } \\
\text { group: }\end{array}$ & & & & & & & & \\
\hline $\begin{array}{l}\text { CEO } \\
\text { received } \\
\text { no } \\
\text { options } \\
\text { in year }\end{array}$ & 87 & & 79 & & 129 & & 295 & \\
\hline $\begin{array}{l}\text { CEO } \\
\text { received } \\
\text { options }\end{array}$ & 63 & 85 & 68 & 78 & 32 & 35 & 163 & 198 \\
\hline Total & & & & & & & & \\
\hline Total & 227 & & 224 & & 245 & & 696 & \\
\hline
\end{tabular}

Where:

Cash group $=\quad$ CEO receives cash, and there is no equity-based compensation scheme in place

Equity group $=\quad$ CEO receives cash and equity-based compensation

Table 2.2 shows that out of the total sample, 235 (34\%) of firms belong to the cash group, and $458(66 \%)$ to the equity group, with 163 of the 458 equity firms receiving equity grants within the year in question. Interestingly, no firm changed group over the three years ${ }^{27}$, which implies that in the short-term, firms are stable in their choice of compensation structure. Firms in the cash group have no provision at all to provide

\footnotetext{
${ }^{26}$ In each case the number of grants is the number of separate option grants made during the year. That is, some firms made more than one option grant to their CEO in any given year.

${ }^{27}$ In that no firm instituted a new equity-based compensation scheme during this period.
} 
equity-based compensation to their CEOs, which is very different from the United States' results presented by Murphy (1999), where he states that most firms have some provision for equity-based compensation [page 2491], even if option grants are not made every year. This implies that while the United States' compensation market has moved towards similar pay structures, there has been less herding in the Australian market. Over this time period and the period studied by Murphy (1999), there were few requirements to expense option based compensation in Australia or the United States for accounting purposes ${ }^{28}$. However, in the United States, favourable income tax treatment was also available [Murphy (1999)], as it was possible for the awarding firm to obtain an income tax deduction for non-qualified options, while there was no such similar formal tax deduction available in Australia. This "double benefit" available in the United States could provide some reasons for the popularity of option based compensation. The lack of herding observed in the Australian market could be influenced by the relatively higher cost of equity-based compensation owing to the tax regulations, or it could be as a result of the lack of compensation disclosure prior to 1 July 1998. However if the lack of compensation disclosures were the primary cause, then an increase in firms using equity-based compensation could be observed after the new compensation disclosures. As an increase in the use of equity-based compensation is not observed in this sample period, it seems that some firms are making the decision not to provide equity-based compensation. One possible explanation for the lack of equity-based compensation is that it is inefficient for firms to use equity-based

\footnotetext{
${ }^{2 x}$ In the United States fair market value and premium options are not expensed for accounting purposes [Murphy (1999)] while in Australia stock options are mostly recognised on exereise [Coulton and Taylor (2002b)]
} 
compensation as part of the CEO compensation structure. This explanation is examined in Chapter Three, where the links between the firm characteristics that are expected to drive compensation contract choice and the compensation structure used by the firm are examined.

While compensation structure choice appears relatively stable, Table 2.2 also shows that there is change in the number of firms making option grants in the equity group, with a sharp decline in the number of option grants made in the 2001 year. The firms themselves do not comment on the lower levels of option grants in this year; however there were market-wide occurrences that could provide some explanation for this result, as 2001 saw a period of general market uncertainty following the Dot-Com and NASDAQ crash. Bushman and Smith (2001) state that in determining performance measures and / or components of any compensation scheme, both the ability of the agent to influence the measure and the informativeness of that measure in signalling effort could be considered. In a period of market uncertainty such as the Dot-Com and NASDAQ crash, the ability of the CEO to influence the firm's stock price could be significantly compromised, and thus tying compensation to stock price through stock options could have become inefficient, and explain the drop in the use of options in the 2001 yejar.

The proportion of firms making grants in Australia is also lower than that in the United States. While Murphy (1999) reports that $63 \%$ of his firms made option grants in the 1992 year and Core and Guay (1999) find that in 74\% of their CEO-year observations 
between 1992 and 1997 option grants are made, this Chapter finds that on average, only $36 \%$ of the equity firms made option grants over the sample period ${ }^{29}$.

Table 2.3 shows the number and percentage of firms in each compensation group that use the different reported components of compensation:

TABle 2.3 - Number and Percentage of Firm-Years using EaCh REPORTEd COMPENSATION COMPONENT:

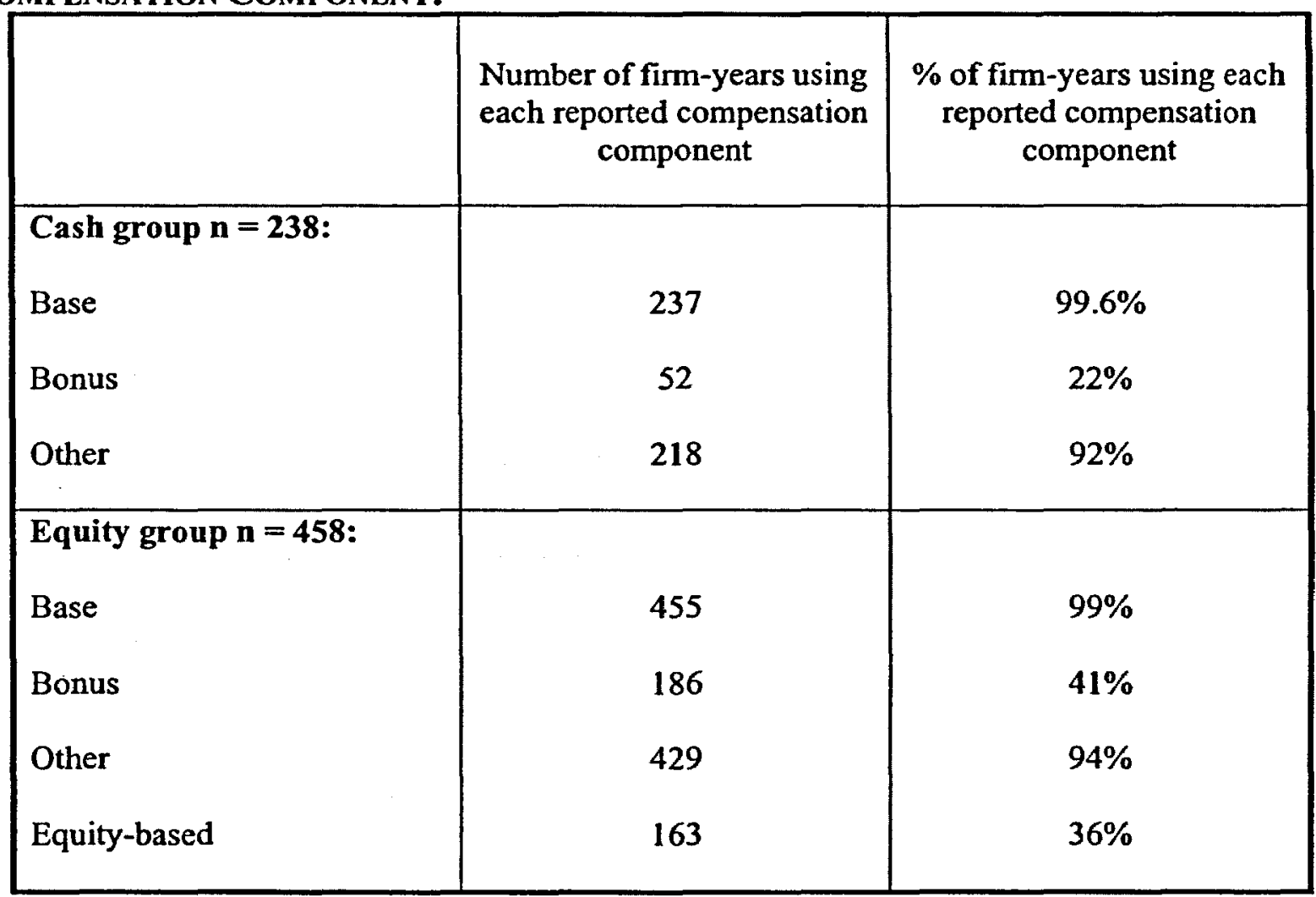

Where:

Cash group $=$

CEO receives cash, and there is no equity-based compensation

Equity group $=$ scheme in place

Base $=$

CEO receives cash and equity-based compensation

Bonus $=$

Base compensation reported by firms in year $t$

Other $=$

Bonus compensation reported by firms in year $t+1$

Equity-based $=$

Other compensation reported by firms in year $t$

Equity-based compensation granted as reported by firms in year $t$

\footnotetext{
${ }^{29}$ Australian firms also appear not to make option grants every year, as only 6 firms in the sample made an option grant to their CEO in each of the sample years. However, neither Murphy (1999) nor Core and Guay (1999) offer any evidence on similar United States practices.
} 
Table 2.3 shows that while most CEOs received a base salary, one firm in the cash group and three firms in the equity group paid no base salary to their CEOs. In each of these instances, the only type of remuneration received by the CEO was "other", which represents primarily non cash benefits (or fringe benefits), consulting fees and superannuation. There is no explicit explanation given in the annual reports for the lack of a base salary. However, two of the firms' annual reports disclose that the CEOs are also paid through an associated company. In the other two firms the reports contain no explanation at all, but in these firms the CEOs have a relatively high shareholding of $22 \%$ and $66 \%$ respectively.

Overall, $34 \%$ of CEOs received a bonus, and CEOs in the equity group are more likely to receive a bonus (at $41 \%$, compared to $22 \%$ in the cash group). This result could possibly indicate that the firm performance in the equity group was higher, so more bonus hurdles were met. However, Chapter Four of this thesis shows that there are no significant differences in firm performance between the cash and equity firms. Consequently, an alternative explanation could be that the bonus hurdles are lower in the equity group compared to the cash group.

The percentage of CEOs receiving "other" compensation is similar between the two groups at $92 \%$ and $94 \%$ for the cash and equity groups respectively. As "other" usually includes superannuation, the high percentage is not surprising given the compulsory superannuation regime in Australia. Those CEOs not receiving "other" might not be 
classifying the compulsory superannuation as part of that category, or could be exempt from the compulsory regime. The main reason for exemption would be that the CEO already has the maximum superannuation benefits, or that the CEO is over 70 years of age $^{30}$.

\subsubsection{Compensation characteristics by industry and group}

All of the firms in the sample were classified into 4 broad industry categories of "mining", "manufacturing", "banking \& finance" and "other", and Table 2.4 below shows the percentage of firms using each compensation contract across industry:

TABle 2.4 - Percentage of Firms using Each Compensation Contract by INDUSTRY

\begin{tabular}{|l|c|c|c|c|}
\hline Industry & Mining & Manufacturing & $\begin{array}{c}\text { Banking \& } \\
\text { Finance }\end{array}$ & Other \\
\hline Cash Group: & $32 \%$ & $30 \%$ & $38 \%$ & $40 \%$ \\
\hline Equity Group: & $68 \%$ & $70 \%$ & $62 \%$ & $60 \%$ \\
\hline
\end{tabular}

\footnotetext{
${ }^{30}$ Although if the CEO is also a director, this may not be likely as there is an effective age limit of 72 year of age for directors. To
} remain a director after $\mathbf{7 2}$, a $75 \%$ vote of appointment by all shareholders must be made at each Annual General Meeting. 
Table 2.4 indicates that each industry has the two different types of compensation contract, and the distribution across each industry is relatively similar, with the highest levels of equity contracts in the manufacturing industry (70\%), and the lowest in the other industry $(60 \%)^{31}$. Splitting the sample into ASX and GICS industry classifications also shows that both types of compensation contract are observed in all industry classifications. These industry results show that the lack of herding is observed across all industries, rather than limited to specific industries, which potentially implies that there are some reasons other than industry membership that is driving compensation structure choice ${ }^{32}$.

Graphs 2.1A to 2.1D and Tables 2.5A to 2.5D show the variation in CEO compensation levels and design across each broad industry group averaged across all three sample years. These results suggest that the levels of compensation differ significantly across the two compensation groups, and across industry.

\footnotetext{
${ }^{31}$ Chi-square tests show that the differences in group membership between the manufacturing and other industry are marginally significant ( $5 \%$ level). None of the differences between the other groups are significant at all.

32 Altematively, these broad industry classifications could be too broad to pick up differences across industries. However, as noted above, industry was also split on the ASX and GICS classifications and both types of compensation contract are observed across the different industries in these finer industry classifications.
} 
GRAPHS 2.1A- 2.1D - LEVEL AND COMPOSITION OF TOTAL CEO COMPENSATION BY INDUSTRY AND COMPENSATION GROUP:
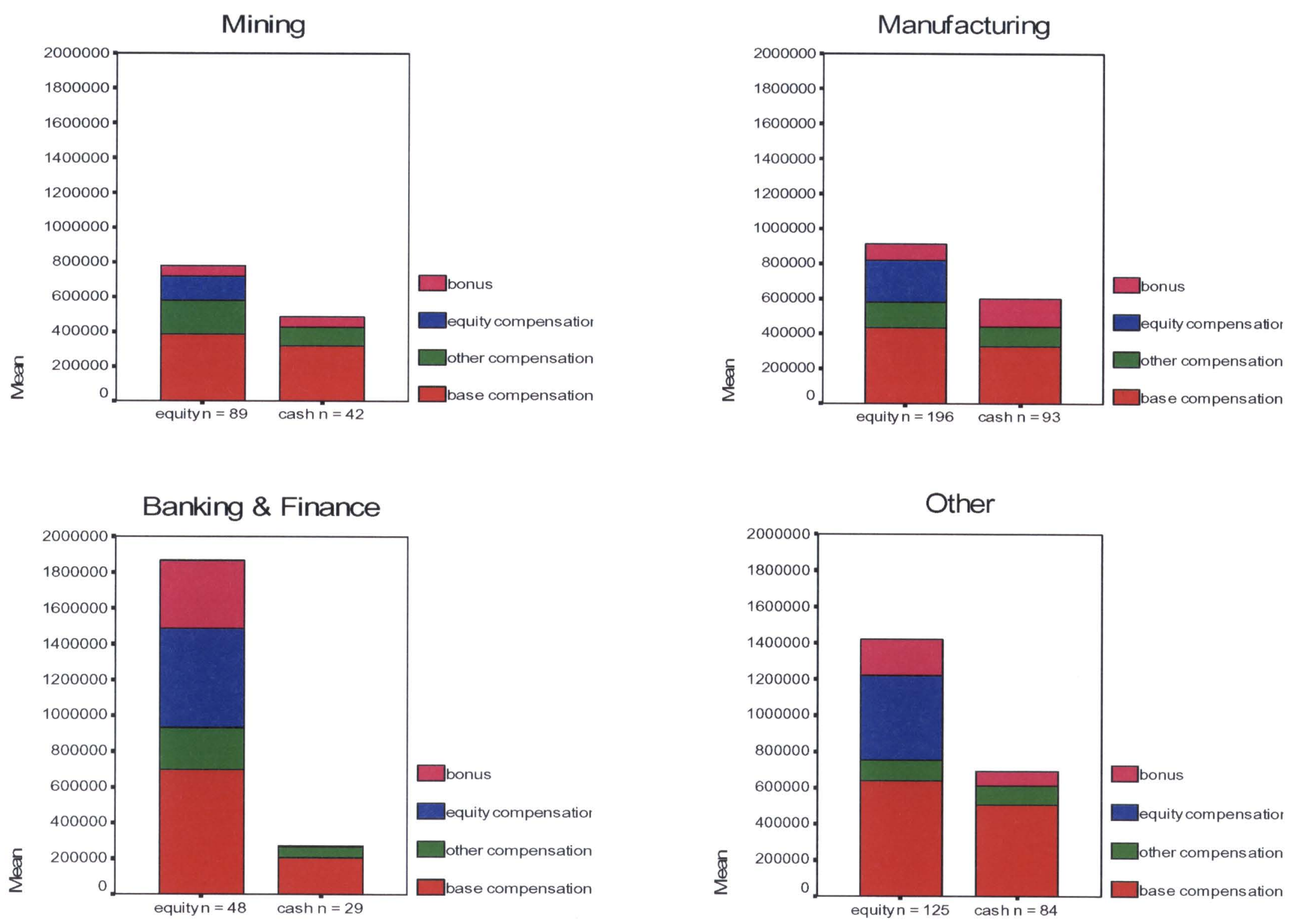
TABle 2.5A - Compensation ChaRACteristics by COMPENSATION GROUP - Mining INDUSTRY:

\begin{tabular}{|c|c|c|c|c|c|c|c|c|c|c|}
\hline Industry & \multicolumn{10}{|c|}{ Mining } \\
\hline $\begin{array}{l}\text { Compensation } \\
\text { Group }\end{array}$ & \multicolumn{5}{|c|}{$\begin{array}{l}\text { Cash } \\
n=42\end{array}$} & \multicolumn{5}{|c|}{$\begin{array}{l}\text { Equity } \\
\underline{n=89}\end{array}$} \\
\hline & Base & Bonus & Other & Equity & Total & Base & Bonus & Other & Equity & Total \\
\hline $\begin{array}{l}\text { Mean-level } \\
\text { Mean-\% of } \\
\text { total } \\
\text { compensation }\end{array}$ & $\begin{array}{r}318,720 \\
65 \%\end{array}$ & $\begin{array}{r}62,254 \\
13 \%\end{array}$ & $\begin{array}{r}106,711 \\
22 \%\end{array}$ & $\begin{array}{r}0 \\
0 \%\end{array}$ & 487,685 & $\begin{array}{r}389,447 \\
50 \%\end{array}$ & $\begin{array}{r}60,564 \\
8 \%\end{array}$ & $\begin{array}{r}187,450 \\
24 \%\end{array}$ & $\begin{array}{r}142,211 \\
18 \%\end{array}$ & 779,674 \\
\hline Median & 234,467 & 0 & 54,125 & 0 & 315,645 & 289,000 & 0 & 53,934 & 0 & 493,993 \\
\hline $\begin{array}{l}\text { Standard } \\
\text { deviation }\end{array}$ & 294,482 & 245,489 & 199,689 & 0 & 576,936 & 325,747 & 199,787 & 710,241 & 365,478 & $1,030,402$ \\
\hline Minimum & 0 & 0 & 0 & 0 & 32,418 & 0 & 0 & 0 & 0 & 4,398 \\
\hline Maximum & $1,143,000$ & $1,511,000$ & 858,605 & 0 & $2,678,000$ & $1,625,000$ & $1,478,500$ & $6,239,739$ & $2,556,928$ & $7,823,072$ \\
\hline $\begin{array}{l}\text { Where: } \\
\text { Base = } \\
\text { Bonus = } \\
\text { Other = } \\
\text { Equity = } \\
\text { Total = }\end{array}$ & $\begin{array}{l}\text { Cotal } \$ \text { base cc } \\
\text { rotal } \$ \text { bonus } \\
\text { rotal } \$ \text { other } \mathrm{c} \\
\text { cotal } \$ \text { Black- } \\
\text { jum of individ }\end{array}$ & $\begin{array}{l}\text { mpensation } \\
\text { mpensation r } \\
\text { choles value } \\
\text { al componen }\end{array}$ & $\begin{array}{l}\text { orted by fin } \\
\text { eported by } f \\
\text { ported by fir } \\
\text { f equity-bas } \\
\text { of compen }\end{array}$ & $\begin{array}{l}\text { s in year } \\
\text { ms in year } \\
\text { ns in year } \\
\text { d compens } \\
\text { ation }\end{array}$ & $\begin{array}{l}t+1 \\
\text { ation grante }\end{array}$ & eported $b$ & $\mathrm{~ms}$ in year $\mathrm{t}$ & & & \\
\hline
\end{tabular}


TABle 2.5B - COMPENSATION ChaRACTERISTICS By COMPENSATION GROUP - MANUFACTURING INDUSTRY:

\begin{tabular}{|c|c|c|c|c|c|c|c|c|c|c|}
\hline Industry & \multicolumn{10}{|c|}{ Manufacturing } \\
\hline $\begin{array}{l}\text { Compensation } \\
\text { Group }\end{array}$ & \multicolumn{5}{|c|}{$\frac{\text { Cash }}{n=83}$} & \multicolumn{5}{|c|}{$\frac{\text { Equity }}{n=196}$} \\
\hline & Base & Bonus & Other & \begin{tabular}{|l|} 
Equity \\
\end{tabular} & Total & Base & Bonus & Other & Equity & Total \\
\hline $\begin{array}{l}\text { Mean-level } \\
\text { Mean-\% of } \\
\text { total } \\
\text { compensation }\end{array}$ & $\begin{array}{r}325,934 \\
54 \%\end{array}$ & $\begin{array}{r}161,662 \\
27 \%\end{array}$ & $\begin{array}{r}111,074 \\
19 \%\end{array}$ & $\begin{array}{r}0 \\
0 \%\end{array}$ & 598,669 & $\begin{array}{r}430,903 \\
47 \%\end{array}$ & $\begin{array}{r}90,801 \\
10 \%\end{array}$ & $\begin{array}{r}146,753 \\
16 \%\end{array}$ & $\begin{array}{r}242,648 \\
27 \%\end{array}$ & 911,106 \\
\hline Median & 268,366 & 0 & 56,239 & 0 & 305,674 & 323,419 & 0 & 70,398 & 0 & 481,003 \\
\hline $\begin{array}{l}\text { Standard } \\
\text { deviation }\end{array}$ & 230,497 & 783,265 & 249,693 & 0 & $1,119,037$ & 318,067 & 227,808 & 330,082 & 792,250 & $1,031,731$ \\
\hline Minimum & 29,244 & 0 & 0 & 0 & 31,270 & 0 & 0 & 0 & 0 & 4,800 \\
\hline Maximum & $1,224,510$ & $6,716,000$ & $2,124,000$ & 0 & $9,760,000$ & $1,603,923$ & $2,006,139$ & $3,667,301$ & $6,177,701$ & $6,454,733$ \\
\hline
\end{tabular}

Where:

Base $=\quad$ Total $\$$ base compensation reported by firms in year $t$

Bonus = Total $\$$ bonus compensation reported by firms in year $t+1$

Other $=\quad$ Total $\$$ other compensation reported by firms in year $t$

Equity $=\quad$ Total $\$$ Black-Scholes value of equity-based compensation granted as reported by firms in year $t$

Total $=\quad$ Sum of individual components of compensation 
TABLE 2.5C - COMPENSATION ChaRACTERISTICS By COMPENSation GROUP - Banking \& FinanCE INDUSTRY:

\begin{tabular}{|c|c|c|c|c|c|c|c|c|c|c|}
\hline Industry & \multicolumn{10}{|c|}{ Banking \& Finance } \\
\hline $\begin{array}{l}\text { Compensation } \\
\text { Group }\end{array}$ & \multicolumn{5}{|c|}{$\begin{array}{l}\text { Cash } \\
n=29\end{array}$} & \multicolumn{5}{|c|}{$\begin{array}{l}\text { Equity } \\
n=48\end{array}$} \\
\hline & Base & Bonus & Other & Equity & Total & Base & Bonus & Other & Equity & Total \\
\hline $\begin{array}{l}\text { Mean - level } \\
\text { Mean - \% of } \\
\text { total } \\
\text { compensation }\end{array}$ & $\begin{array}{r}209,401 \\
76 \%\end{array}$ & $\begin{array}{r}7,897 \\
3 \%\end{array}$ & $\begin{array}{r}57,455 \\
21 \%\end{array}$ & $\begin{array}{r}0 \\
0 \%\end{array}$ & 274,759 & $\begin{array}{r}702,022 \\
38 \%\end{array}$ & $\begin{array}{r}380,649 \\
20 \%\end{array}$ & $\begin{array}{r}230,313 \\
12 \%\end{array}$ & $\begin{array}{r}552,022 \\
30 \%\end{array}$ & $1,865,007$ \\
\hline Median & 191,529 & 0 & 36,654 & 0 & 250,000 & 584,502 & 22,500 & 77,012 & 18,444 & $1,153,210$ \\
\hline $\begin{array}{l}\text { Standard } \\
\text { deviation }\end{array}$ & 154,276 & 24,446 & 112,923 & 0 & 237,349 & 464,644 & 838,986 & 637,294 & $1,071,265$ & $1,786,112$ \\
\hline Minimum & 24,600 & 0 & 1,722 & 0 & 26,322 & 57,857 & 0 & 0 & 0 & 163,500 \\
\hline Maximum & 528,324 & 100,000 & 617,976 & 0 & $1,092,976$ & $1,853,394$ & $4,185,686$ & $4,089,025$ & $5,452,625$ & $9,134,865$ \\
\hline
\end{tabular}

Base $=$

Bonus $=$

Total $\$$ base compensation reported by firms in year $t$

Other $=\quad$ Total $\$$ other compensation reported by firms in year $\mathrm{t}$

Equity $=\quad$ Total $\$$ Black-Scholes value of equity-based compensation granted as reported by firms in year $t$

Total $=\quad$ Sum of individual components of compensation 
TABLE 2.5D - COMPENSATION CHARACTERISTICS BY COMPENSATION GROUP - OTHER INDUSTRY:

\begin{tabular}{|c|c|c|c|c|c|c|c|c|c|c|}
\hline Industry & \multicolumn{10}{|c|}{ Other } \\
\hline $\begin{array}{l}\text { Compensation } \\
\text { Group }\end{array}$ & \multicolumn{5}{|c|}{$\begin{array}{l}\text { Cash } \\
n=84\end{array}$} & \multicolumn{5}{|c|}{$\frac{\text { Equity }}{n=125}$} \\
\hline & Base & Bonus & Other & Equity & Total & Base & Bonus & Other & Equity & Total \\
\hline $\begin{array}{l}\text { Mean-level } \\
\text { Mean - \% of } \\
\text { total } \\
\text { compensation }\end{array}$ & $\begin{array}{r}507,086 \\
73 \%\end{array}$ & $\begin{array}{r}77,914 \\
11 \%\end{array}$ & $\begin{array}{r}108,571 \\
16 \%\end{array}$ & $\begin{array}{r}0 \\
0 \%\end{array}$ & 693,572 & $\begin{array}{r}640,927 \\
41 \%\end{array}$ & $\begin{array}{r}203,152 \\
13 \%\end{array}$ & $\begin{array}{r}13,381 \\
7 \%\end{array}$ & $\begin{array}{r}464,995 \\
39 \%\end{array}$ & $1,422,950$ \\
\hline Median & 337,164 & 0 & 58,192 & 0 & 434,801 & 500,000 & 0 & 75,205 & 0 & 782,600 \\
\hline $\begin{array}{l}\text { Standard } \\
\text { deviation }\end{array}$ & 640,438 & 212,271 & 171,572 & 0 & 836,776 & 500,319 & 452,857 & 143,291 & $1,557,424$ & $1,716,499$ \\
\hline Minimum & 30,000 & 0 & 0 & 0 & 30,000 & 156,000 & 0 & 0 & 0 & 187,088 \\
\hline Maximum & $4,008,000$ & $1,200,000$ & $1,219,926$ & 0 & $4,734,476$ & $3,645,511$ & $2,997,016$ & 675,098 & $10,450,102$ & $10,865,032$ \\
\hline
\end{tabular}

Where:

Base $=\quad$ Total $\$$ base compensation reported by firms in year $\mathrm{t}$

Bonus = $\quad$ Total $\$$ bonus compensation reported by firms in year $t+1$

Other $=\quad$ Total $\$$ other compensation reported by firms in year $\mathrm{t}$

Equity = Total $\$$ Black-Scholes value of equity-based compensation granted as reported by firms in year $t$

Total $=\quad$ Sum of individual components of compensation 
Graphs 2.1A to 2.1D and Tables 2.5A to $2.5 \mathrm{D}$ reveal some interesting observations on Australian CEO compensation. First, consistent across each industry group, CEOs in the equity group receive higher average compensation, both averaged across all three years and in each individual year ${ }^{33}$ [across 3 years, cash vs. equity - mining $\$ 487,685$ vs. $\$ 779,674$; manufacturing $\$ 598,669$ vs. $\$ 911.106$; banking and finance $\$ 274,759$ vs. $\$ 1,865,007$; other $\$ 693,572$ vs. $\$ 1,422,950]$. Even after removing the value for the equity-based compensation, the equity group are paid more, on average, than the cash group [cash vs. equity - mining $\$ 487,685$ vs. $\$ 637,463$; manufacturing $\$ 598,669$ vs. $\$ 668,458$; banking and finance $\$ 274,759$ vs. $\$ 1,312,985$; other $\$ 693,572$ vs. $\$ 959,955$ ]. Further, in each industry, the equity group receives a higher mean base salary [cash vs. equity - mining $\$ 318,720$ vs. 389,447 ; manufacturing $\$ 325,934$ vs. 430,903 ; banking and finance $\$ 209,401$ vs. $\$ 702,022$; other $\$ 507,086$ vs. $\$ 640,927]$. Demsetz and Lehn (1985), Smith and Watts (1992) and Gaver and Gaver (1993) argue that equity-based compensation could be used where direct monitoring of the CEO is difficult, such as when firms are larger and more decentralised and complex. Core, Holthausen and Larcker (1999) also suggest that larger and more complex firms need a better quality $\mathrm{CEO}$, and that the higher the quality of the CEO, the higher the relative compensation. These arguments provide some explanation for the higher levels of compensation in the equity group compared to the cash group, and detailed examination of these is made in Appendix 2.B, which shows that the level of CEO compensation is positively related to firm size and firm complexity.

\footnotetext{
${ }^{3}$ Individual year results are not reported.
} 
Second, consistent with the United States' evidence presented by Murphy (1999), the highest paid CEOs in the equity group are in the banking and finance industry with an average total compensation of $\$ 1,865,007$ (median $\$ 1,153,210$ ) over the three years. However, compared to the United States' results reported by Murphy (1999), Australian CEOs receive much lower pay, with Murphy (1999) reporting that the median United States' CEO compensation for the 1996 year in Financial Services of USD $\$ 4,582,000$. This is also consistent with the Towers Perrin reports that indicate that CEOs in the United States are the most highly paid in the world. Interestingly, the lowest paid Australian CEOs are also in the banking and finance industry, but in the cash group, with mean compensation of $\$ 274,759$ (median 250,000 ). If the firm characteristics and therefore jobs of these CEOs were similar, it would be expected that benchmarking would drive compensation levels together. However, the large differences imply that there must be some significant differences in the firms and the jobs of these CEOs, even within the same industry.

Third, the minimum compensation amounts are very low [(cash vs. equity) mining $\$ 32,418$ vs. $\$ 4,398$; manufacturing $\$ 31,270$ vs. $\$ 4,800$; banking and finance $\$ 26,322$ vs. $\$ 163,500$; other $\$ 30,000$ vs. $\$ 187,088$ ]. Out of the total sample over the three years there are 36 observations of total compensation of less than $\$ 100,000$, representing 18 firms in total. Out of those 18 firms, 13 were awarded less than $\$ 100,000$ to their CEO in every year that they were in the sample. One potential explanation for low total compensation could be that the CEO owns a large portion of the firm's stock. Of those 13 firms, 7 had CEOs who owned $4 \%$ or more of the common stock, leaving 6 firms in 
which the CEO owned very little stock and received only minimal compensation. In these firms there was no comment on the level of compensation received in the annual report. One possible explanation for this finding is that not all CEOs work full-time for their employers. However, it is not possible to test this explanation as there is no data in annual reports on compensation received by the CEO from all sources (for example, whether the CEO receives some compensation from a non-consolidated affiliate). Alternatively, these CEOs could be receiving some type of compensation not reported in the disclosure. However, as all taxable fringe benefits ${ }^{34}$ are included as part of the "other" disclosure, it would be unlikely that there is any undisclosed compensation. Of the remaining 5 firms, one changed CEO in 2000 and the new CEO received $\$ 789,877$ in the 2001 year, three paid their CEOs more than $\$ 100,000$ in the 2001 year, and one paid their CEO over $\$ 300,000$ in 1999 and less than $\$ 100,000$ in 2000 and 2001. All of the changes in compensation were in base salary and other. No change was due to the issue of options or a bonus. As there is no commentary on compensation changes year to year in the annual reports, it is difficult to determine the reason for these changes in compensation.

Fourth, the structure of the comparable pay components is also different between the two compensation groups. Although the equity group receives the highest mean base salary in each industry, base salary forms a higher percentage of compensation in the cash group compared to the equity group [(cash vs. equity) mining $65 \%$ vs. $50 \%$; manufacturing $54 \%$ vs. $47 \%$; banking and finance $76 \%$ vs. $38 \%$; other $73 \%$ vs. $41 \%$ ].

\footnotetext{
${ }^{34}$ Taxable fringe benefits include any type of non cash benefit provided to an employee or to their associates.
} 
The bonus proportion and dollar value is higher in the cash group compared to equity in the mining [cash $13 \%$, equity $8 \%$ ] and manufacturing [cash $27 \%$, equity $10 \%$ ] industries, but the opposite is found in the banking and finance [cash $3 \%$, equity $20 \%$ ] and other [cash $11 \%$, equity $13 \%$ ] industries. Again, this result could be due to differences in the performance hurdles for the bonuses, and / or that some bonuses hurdles are set lower than others.

\subsubsection{Level of CEO Compensation and Firm Characteristics - Appendix 2.B}

Section 2.4.2 reveals that the level of CEO compensation varies across industry and compensation group membership, and academic research has argued that the efficient level of CEO compensation packages could vary across firms, dependent on the underlying economic characteristics of the firm [Jensen and Meckling (1976), Core, Holthausen and Larcker (1999)]. Appendix 2.B provides further explanation of the variation in the level of CEO compensation awarded by comparing levels of CEO compensation to the various determining firm characteristics suggested by the prior literature, and compares these results to those found for the United States. Appendix

2.B also improves on the empirical designs used in the prior literature by using separate proxies for firm size and complexity, as well as including proxies for current firm performance.

Appendix 2.B adopts a traditional agency perspective, and following the prior literature expects that on average, the level of CEO compensation could be set based on the 
underlying economic characteristics of the firm that determine the demand for relative quality in the CEO [Core, Holthausen and Larcker (1999)]. Using the same data set as Chapter Two, Appendix 2.B finds that the level of CEO compensation in the total sample is significantly positively related to firm size, complexity and current market performance, and more weakly positively related to growth options, prior market performance and current accounting performance. Appendix 2.B also shows that with the exception of firm size, the significance of the other firm characteristics differs across both the compensation and industry groups.

Appendix 2.B also provides some comparison to results found in the United States [Core, Holthausen and Larcker (1999)]. Core, Holthausen and Larcker (1999) use total sales to proxy for both firm size and complexity and find significant positive relations with total compensation. Appendix 2.B uses different measures for complexity and size and finds that both size and complexity have a positive significant relation to total compensation. While Core, Holthausen and Larcker (1999) find a strong positive relation on the prior market returns measure, the same is not observed in this sample. Core, Holthausen and Larcker (1999) find no result for the prior performance (ROA) measure, and Appendix 2.B finds similar results. Appendix 2.B finds opposite results on the growth options variable, although the significance is weak. Finally, while Core, Holthausen and Larcker (1999) find a negative association between risk and compensation, Appendix 2.B finds no relation. 
These results suggest that as well as having different compensation structures from the United States, Australian levels of compensation could also be determined on a different basis to those in the United States, especially in relation to the proxies for growth options and risk. However, one possible explanation is the differences in the proxies used to measure firm size between this study and the Core, Holthausen and Larcker (1999) study. In order to determine whether it is the proxies used that are driving the different results, the regression is re-estimated using sales as a proxy for both firm size and complexity, ${ }^{35}$ and the results remain similar.

Thus the results in Appendix 2.B indicate that Australian firms set levels of compensation somewhat differently to firms in the United States, which further suggests that studying CEO compensation in Australia provides new opportunities for research. However, although the results are different to those obtained in the United States, they indicate that the levels of CEO compensation in Australia are related to the underlying economic characteristics of the firm, rather than being randomly decided.

\footnotetext{
${ }^{35}$ The model is also re-estimated using sales as only firm size and including the subsidiaries measures as proxies for firm complexity.
} 


\subsubsection{Option grant characteristics}

Of the 458 firm years in the equity group, 163 companies made 198 option grants to their CEOs in the sample period (refer Table 2.2). Table 2.6 describes the characteristics of the option grants, and also provides the results from Murphy (1999) for comparison to the United States:

TABle 2.6-Option Grant ChaRacteristics:

\begin{tabular}{|c|c|c|c|c|}
\hline & \multicolumn{2}{|c|}{$\begin{array}{l}\text { Option grants: } \\
{\text { (total } n=198)^{36}}\end{array}$} & \multicolumn{2}{|c|}{$\begin{array}{l}\text { Murphy (1999): } \\
\text { US results }\end{array}$} \\
\hline & number & $\%$ & number & $\%$ \\
\hline $\begin{array}{l}\text { Exercise prices: } \\
\text { Exercise price at Fair Market Value (FMV) } \\
\text { "Discount" (Exercise price < FMV) } \\
\text { "Premium" (Exercise price > FMV) } \\
\text { Other }\end{array}$ & $\begin{array}{c}106 \\
35 \\
57 \\
0\end{array}$ & $\begin{array}{l}54 \% \\
18 \% \\
29 \%\end{array}$ & $\begin{array}{c}692 \\
22 \\
11 \\
3\end{array}$ & $\begin{array}{c}95 \% \\
3 \% \\
1.5 \% \\
0.4 \%\end{array}$ \\
\hline $\begin{array}{l}\text { Term of Option: } \\
\text { Term }<5 \text { years } \\
\text { Term }=5 \text { years } \\
5 \text { years }<\text { term }<10 \text { years } \\
\text { Term }=10 \text { years } \\
\text { Term }>10 \text { years } \\
\text { Other }\end{array}$ & $\begin{array}{c}62 \\
111 \\
13 \\
12 \\
0 \\
0\end{array}$ & $\begin{array}{c}31 \% \\
56 \% \\
6.5 \% \\
6 \%\end{array}$ & $\begin{array}{c}14 \\
41 \\
41 \\
602 \\
27 \\
2\end{array}$ & $\begin{array}{c}2 \% \\
6 \% \\
6 \% \\
83 \% \\
4 \% \\
0.3 \%\end{array}$ \\
\hline $\begin{array}{l}\text { Performance hurdles: } \\
\text { Yes } \\
\text { No }\end{array}$ & $\begin{array}{c}68 \\
130\end{array}$ & $\begin{array}{l}34 \% \\
66 \%\end{array}$ & $\begin{array}{c}2 \\
726\end{array}$ & $\begin{array}{c}0.3 \% \\
99.7 \%\end{array}$ \\
\hline
\end{tabular}

Where FMV = Exercise price equals stock price on date of option issue.

\footnotetext{
${ }^{36}$ Over the sample period, 163 equity firms made 198 option grants (refer Table 2.2).
} 
Table 2.6 shows that option grants in Australia are quite different from those in the United States. Murphy's results indicate that the characteristics of option awards are fairly generic in the United States, while our results indicate greater variation in Australia. For example, while options in the United States tend to have their exercise prices set at fair market value (FMV) (95\% per Murphy's (1999) results), only $54 \%$ of options have an exercise price equal to FMV in Australia, while $18 \%$ are set at a discount, and $29 \%$ are at a premium. Options that are granted at a premium could appear naturally more likely to create greater incentives for the CEO to increase share price compared to options that are set at FMV or at a discount. On the other hand, options granted at a discount or FMV appear to offer less incentive (especially those at a discount), and so could have been issued more for compensation than for incentive. The performance effects of these different types of options are examined further in Appendix 4.A.

Murphy's results also indicate that United States' options usually have a term of 10 years (83\%), while Australian options are most likely to have a term of 5 years $(56 \%)$. Prior to 1 July 1998, Australian Corporations Law prescribed that the maximum life of an Australian option was 5 years. Since 1 July 1998, there has been no prescribed maximum life, but the high incidence of 5 year maximum terms could have been influenced by this early law.

Finally, while only $0.3 \%$ of Murphy's option awards have performance hurdles in place, $34 \%$ of the option awards made in this sample have some sort of performance hurdle 
attached. This high incidence of performance hurdles in the Australian market is interesting, and there is no clear reason as to why this has occurred ${ }^{37}$. Chapter Four of the thesis investigates the performance aspects of these different option characteristics, including the existence of hurdles, to provide an insight into whether firm performance is related to different option characteristics. The performance implications of hurdles and other option characteristics is interesting, especially given that anecdotal evidence (such as the Australian Shareholders' Association commentaries on a number of proposed option schemes) suggests that shareholders often demand some types of performance hurdles to be in place, and as shareholders must approve option schemes they could have the voting power to ensure that hurdles are in place.

Appendix 2.C summarises the option grant characteristics across the four different industry groups. Overall, it appears that the option grant characteristics are relatively similar across the mining, manufacturing and other industries, with the banking and finance industry appear to have option characteristics possibly more beneficial to the CEO. The performance consequences of these different option characteristics are examined in Chapter Four, to determine whether there are any systematic differences in firm performance across firms using the different types of options. If options in the banking and finance industry are more beneficial to the CEO than what is efficient, lower firm performance could also be expected compared to other firms and industries using alternative option characteristics.

\footnotetext{
${ }^{37}$ However, more curious could be why there is a lack of performance hurdles in the United States. The lack of hurdles in the United States could be due to the favourable accounting and taxation treatment only being available for fair market value options with set terms and no performance hurdles attached.
} 
Appendix 2.D provides information on the combinations of the option characteristics across the option grants and indicates that firms are using different combinations of option characteristics. Appendix 2.E reports the variance in option grant behaviour by individual firms. Appendix 2.E shows some variance in the use of exercise price types, with the most popular combination being FMV and premium options. Option terms appear to have the least variation, with the majority of firms using the same option term in each option grant made, and there appears to be a trend away from the use of performance hurdles, which is curious given the apparent pressure on firms to use these hurdles.

\section{$2.5 \quad$ IMPLICATIONS OF FINDINGS}

Using comprehensive compensation data available from 1 July 1998, this Chapter provides the first detailed descriptive evidence of CEO compensation practices in the Australian market, and finds significant variation in compensation structures across firms. Unlike firms in the United States, some Australian firms offer their CEOs no equity-based compensation, nor do they have any provisions in place to offer equitybased compensation. Further, those firms that do offer equity-based compensation offer different types of option grants, again different than the relatively homogeneous option grants observed in the United States' market. 
This variation in compensation structures is observed equally across all industry groups, hence it is difficult to argue that the variation is a function of industry group membership. These findings are further investigated in Chapter Three of this thesis. Core, Holthausen and Larcker (1999) and Ittner Lambert and Larcker (2003) suggest that compensation contracting (both levels and structure) is set based on the underlying economic characteristics of the firm. Following the prior literature, Chapter Three investigates the relation between CEO compensation structure and firm characteristics.

Chapter Four examines the performance consequences of compensation structure for the equity and cash groups of firms. If firms are not choosing appropriate compensation structures, lower performance would be expected. Chapter Four first investigates whether on average there are differences in firm performance across the two compensation structures, to see whether there are any systematic differences in firm performance (both accounting and market performance) based on compensation type groups. Further, Chapter Four uses the theorised predictors of compensation structure choice to predict efficient compensation structures. Next, firms deviating from the efficient compensation structure are identified, and the performance of the firms identified as having efficient structures is compared to those firms identified with sub efficient compensation contracts. The conclusions to the thesis are contained in Chapter Five. 


\section{CHAPTER 3}

\section{THE RELATION BETWEEN FIRM CHARACTERISTICS AND CEO COMPENSATION}

\section{STRUCTURE}

\subsection{INTRODUCTION}

Chapter Two shows that significant variation in CEO compensation structures is observed in the Australian market. Unlike firms in the United States, around one-third of large Australian firms offer their CEOs no equity-based compensation at all, nor do they have any provisions in place to offer equity-based compensation [the cash group]. In addition, Chapter Two provides evidence of variation within those firms that do offer equity-based compensation [the equity group] in that these firms offer different types of equity-based compensation, different from the relatively homogeneous equity grants observed in the United States' market. Given that Australian firms' compensation practices are different to those observed in the United States' market, it could be that the variations are an indication of inefficient rather than efficient contracting.

This Chapter investigates one aspect of the question of efficient versus inefficient contracting. Specifically, the objective of this Chapter is to provide the first detailed evidence on the relation between firm characteristics and the structure of CEO compensation in an environment in which not all CEO compensation contracts contain equity-based compensation. If Australian firms are making efficient contract choices, there could be some systematic reasons why the cash group do not offer any equity- 
based compensation, and thus these firms could have significantly different economic characteristics compared to firms that do use equity-based compensation. Alternatively, if Australian firms are random in their choice of compensation structure, then those choices could not be made based on the underlying economic characteristics of the firm. If this is true, then there could be few observable links between firm characteristics and compensation structure choice. Thus this Chapter provides a new insight into the choice of compensation structure.

Chapter Two also indicates that there is much more variation in the type of equity-based compensation awarded in Australia compared to other studies. This Chapter also provides evidence on the links between firm characteristics and the types of equitybased compensation awarded to the $\mathrm{CEO}$, again providing new evidence on practices not documented in the literature to date.

There are two motivations for this Chapter. First, Bushman and Smith (2001) suggest that the use of different performance measures (equity versus accounting) could be determined by the underlying economic characteristics of the firm. Matolcsy (2000) provides evidence that cash-based compensation is driven by accounting rather than equity performance measures, and thus the use of different compensation structures could reflect the use of different performance measures, and thus be used by different types of firms. However, the literature to date concentrates on a data set in which the CEO is routinely offered some level of equity-based compensation, thereby providing evidence on the relation between firm characteristics and the percentage or level of 
equity-based compensation awarded to the CEO [for example, Ryan and Wiggins (2001), Core and Guay (2001), Ittner, Lambert and Larcker (2003)]. Consequently, while the existing evidence is extensive, there has been very little analysis of firms that do not award any form of equity-based compensation to their CEOs. This Chapter uses the two distinct compensation structures identified in Chapter Two - firms using equitybased compensation in the CEO's contract (the equity group) and firms that do not (the cash group), and investigates the links between the choice of compensation structure and the underlying economic characteristics of the firm.

The second motivation is that both Australian regulators and investors have indicated interest in management compensation practices, as discussed in Chapter Two. This Chapter provides the first detailed evidence on firm characteristics and Australian CEO compensation structures, thus contributing to the current policy debate by providing information that could be useful to policy makers in their deliberations. While some cursory evidence exists on Australian CEO compensation [Crease, Goodwin and Kent (2001), Coulton and Taylor (2002a)], there is little detailed evidence on the link between the structure of CEO compensation and firm characteristics. This Chapter provides the first detailed analysis of these links, and expands the current Australian evidence by using a bigger data set, actual rather than proxies for CEO compensation, and by examining more firm characteristics, such as firm complexity, noise, cash constraints and CEO share ownership. 
The evidence of this Chapter is based on the same sample used in Chapter Two - a sample of large Australian firms for the period 1999-2001, a total of 696 firm years. All accounting and compensation related data are available from the "UTS-Accenture Who Governs Australia" database, while stock price information is taken from SIRCA.

The results of this Chapter indicate that the economic characteristics of the firms in the cash group are significantly different to those of the firms in the equity group. Consistent with the analytical models that predict the demand for certain levels of equity-based compensation, this Chapter finds that firms in the equity group are significantly larger, more decentralised and have more growth options compared to the cash group, while firms in the cash group have CEOs with far higher levels of current stock ownership. Consequently, this Chapter provides the first evidence that CEO compensation structures are not necessarily inefficient in the Australian market, although they are different from those observed in the existing CEO compensation literature.

The remainder of the Chapter is organised as follows. Section 3.2 reviews the prior descriptive evidence on the structure of compensation contracts both in Australia and the United States. Section 3.3 develops the theory, and section 3.4 describes the research design. Section 3.5 reports the results of the Chapter and the conclusions are contained in section 3.6. 


\subsection{LITERATUREREVIEW}

Agency theory describes an efficient compensation contract as one under which agency costs are minimised [Jensen and Meckling (1976)]. A number of papers have argued that efficient CEO compensation structures vary across firms, dependent on the underlying economic characteristics of the firm [Jensen and Meckling (1976), Demsetz and Lehn (1985), Smith and Watts (1992), Gaver and Gaver (1993), Bushman and Smith (2001)]. The link between firm characteristics and the level or percentage of equity-based compensation granted to the CEO has been well documented in empirical research, but to date, the link between firm characteristics and CEO compensation structure has been largely unexplored. This could be due to the fact that CEO compensation contracting has been researched predominantly in the United States, where the compensation structures are relatively homogeneous.

Investigating equity grants to the CEO, Core and Guay (1999) use a sample of 6,214 CEO-year observations from the ExecuComp database from 1992 to 1997 (United States' data). Using a two stage process, they first estimate the efficient level of CEO equity incentives and find that the levels of incentives provided are positively related to the underlying firm economic characteristics of size, growth opportunities, noise (or risk) and CEO tenure. In the second stage, they show that firms manage grants of new equity in response to deviations from the efficient contract.

Ryan and Wiggins (2001) study the impact of firm characteristics on the percentages of cash bonus, stock options and restricted stock awarded to the CEO using data from 1997 
for 1995 United States' firms from the S\&P 500, the Midcap 400 and the Smallcap 600. Ryan and Wiggins (2001) find that the use of different forms of incentive compensation is linked to firm characteristics. Specifically, they find that cash bonus is negatively related to cash flow volatility, while the use of stock options is positively related to the existence of growth options, capital expenditure, $R \& D$ intensity, firm size and the volatility of cash flows. They also find a negative relation between the use of stock options and CEO age and share ownership, block holder ownership and leverage. Finally, they show that the use of restricted stock is negatively related to $R \& D$ intensity and CEO share ownership, and positively related to firm size.

Ittner, Lambert and Larcker (2003) use a sample of 217 new economy firms over the years 1998 and 1999, and investigate the determinants of the percentage value of equity grants to various types of employees, including the CEO. They find that the important firm characteristics in determining the percentage of equity granted to the CEO are investment opportunities (positive relation), firm size (positive relation), leverage (negative relation) block ownership (negative relation), and retention objectives (positive relation).

There has been very little investigation into the links between firm characteristics and the use of different CEO compensation structures. Using pre 1 July 1998 compensation disclosures, Crease, Goodwin and Kent (2001) investigate the extent to which Australian firms use stock options in CEO compensation contracts, as well as the ex ante incentives for firms to use stock options as part of compensation. Crease, Goodwin 
and Kent (2001) use a sample of 378 out of the top 500 Australian listed firms in 1997, and measure CEO compensation as the mid-point of the highest remuneration band paid. Crease, Goodwin and Kent (2001) find that of their sample, 225 firms (or $59.5 \%$ of firms) have an employee share option scheme in place. Using a dichotomous variable to indicate the use of a share option scheme, Crease, Goodwin and Kent (2001) show that the existence of growth options ${ }^{1}$, the firms' international diversification, and membership in the finance/investment industry are positively associated with the use of share options, while the level of firm leverage was insignificant. However, this study is limited as it does not use many of the explanatory variables suggested in the theoretical literature such as firm complexity, noise, cash constraints and CEO share ownership.

Coulton and Taylor (2002a) also provide some evidence on the links between firm characteristics and CEO compensation structure by studying the incidence of CEO stock option awards using the post 1 July 1998 disclosures on a limited sample of 258 firms for one year. Coulton and Taylor (2002a) find that the stock option awarders are significantly larger (based on market capitalisation) than the non-awarders, while market-to-book and share returns are not significantly different between the two groups. However, unlike Crease, Goodwin and Kent (2001), Coulton and Taylor (2002a) do not use lagged variables to explain the ex ante choice, and also have a very small sample of option awarding firms (73 in total). Further, Coulton and Taylor (2002a) measure the option value at only $25 \%$ of exercise price, while the majority of the United States' literature uses the Black-Scholes valuation method.

\footnotetext{
'Although the sensitivity analysis indicated that this relation only existed for the medium sized firms in the sample.
} 


\subsection{THEORY DEVELOPMENT - THE ECONOMIC DETERMINANTS OF COMPENSATION}

\section{STRUCTURE}

The theoretical literature to date provides only limited guidance on the economic determinants of compensation structure [Ittner, Lambert and Larcker (2003)]. One general stream of theoretical literature that discusses compensation contracting is that of agency theory, and this literature develops the definition of an efficient compensation contract (both level and structure). For example, Jensen and Meckling (1976) argue that one way to resolve the agency problem between the CEO and the shareholders is through the CEO's compensation, as the compensation contract can either induce the CEO to act in the best interests of the shareholders by establishing the proper incentives, or can ensure that the shareholder is compensated by the CEO if the CEO has the potential to take action contrary to the best interests of the shareholder. Consequently, agency theory suggests that an efficient $\mathrm{CEO}$ compensation contract is one under which agency costs are minimised.

Developing this idea, another stream of literature analyses the efficient compensation structure, although not purely in terms of cash-based compensation versus equity-based compensation. Rather, this literature concentrates on the performance measures (accounting and market) that could be included in a compensation contract. For example, Bushman and Smith (2001) develop a framework that identifies the theoretical determinants of the types and weights of the performance measures included in a compensation contract. They formally describe that in an efficient contract, the weight on any one performance measure is determined by the sensitivity of that performance 
measure to managerial action, multiplied by the ratio of the precision of each measure in calculating true firm value (that is, the inverse of noise). Using this framework, Bushman and Smith (2001) argue that the use of accounting numbers as performance measures in compensation contracts can be efficient, and that the accounting performance measures have three roles - to directly create incentives to take actions, to filter noise from other performance measures and to balance managerial effort across multiple activities. ${ }^{2}$

Overall, Bushman and Smith (2001) suggest that the use of a performance measure is determined by the sensitivity of that measure to effort, and the noise of the measure. They also provide some discussion on the operation of this theory, in that they discuss the common approaches to determining the sensitivity and noise of performance measures. Bushman and Smith (2001) first discuss the sensitivity of performance measures to action, and focus on the firm's growth options. They argue that as growth options increase, equity-based performance measures would be used as the accounting numbers would poorly reflect current managerial effort. When discussing the measurement of noise in the performance measure, Bushman and Smith (2001) also focus on firm specific characteristics, and state that the common proxy of noise is the time-series standard deviation of the performance measure.

\footnotetext{
${ }^{2}$ This literature only considers the characteristics of the firm, not of the CEO as well. Risk preferences of the CEO could also impact on a compensation contract [Meulbroek (2001), however are very difficult to measure.
} 
Thus Bushman and Smith (2001) suggest that the use and weight of different performance measures in a compensation contract is determined by the underlying economic characteristics of the firm. As cash-based compensation is driven by accounting performance numbers [Matolcsy (2000)] and equity-based compensation by market performance measures, the implication of Bushman and Smith (2001) could be that firms with different economic characteristics could use different compensation structures, in order to minimise agency costs.

Also following agency theory, another stream of theoretical studies has concentrated on the amount of equity-based compensation that could be awarded to the CEO. These studies argue that firms with different economic characteristics have different demands for the use of equity-based compensation ${ }^{3}$. Specifically, these studies suggest that firms could use more equity-based compensation to align the interests of shareholders and managers when direct monitoring of employees is difficult [Demsetz and Lehn (1985), Smith and Watts (1992), Gaver and Gaver (1993)]. These arguments are consistent with those of Bushman and Smith (2001), as the difficultly in monitoring arises as a result of the relative lack of information in the accounting numbers. These studies suggest that the monitoring of managers through accounting numbers is more difficult (and thus more equity-based compensation is used) in firms where there is more noise in the operating environment and where there are greater growth opportunities. Others argue that monitoring could be more difficult as the firm becomes more complex, so as firm size and decentralisation increases, a greater use of equity-based compensation could be 
expected [Ryan and Wiggins (2001), Core and Guay (2001) Ittner, Lambert and Larcker (2003)].

Cash constraints are also suggested as a determinant of the use of equity-based compensation - where firms are cash constrained, they could substitute equity-based compensation for cash compensation [Core, and Guay (2001), Ittner, Lambert and Larcker (2003)]. Finally, the percentage of shares already owned by the CEO is expected to be important in the choice of awarding equity-based compensation. If the CEO already owns a large percentage of the common stock of the firm, significant incentive alignment with the other shareholders is already in place and additional equitybased compensation might not be necessary [Lambert and Larcker (1987)].

The studies discussed above all theorise as to the structure of the efficient compensation contract. Another stream of debate is whether the currently observed contracts are efficient or not. For example, Ittner, Lambert and Larcker (2003) state that even though all firms could be attempting to set efficient compensation contracts, efficient contracting might not be observed in all firms at any given point of time. However, they also argue that even though efficient contracts might not be observed in cross-section, unless there are systematic biases in the firms' beliefs on contracting, on average compensation contracts could be efficient. Consequently, if compensation contracts are efficient on average, then again on average the choice of compensation structure could relate to the underlying firm characteristics. So following these arguments, and

\footnotetext{
${ }^{3}$ However, these studies are silent as to the proportion of cash-based compensation that could be used.
} 
assuming there are no systematic biases in beliefs, as the cash group uses a very different compensation contract compared to the equity group, it could be expected that if the variation in compensation contract choice observed in the Australian market is efficient, the cash group's economic characteristics could be significantly different to those of the equity group.

Alternatively, the observed variation in compensation structure could be inefficient, in that Australian firms are random in their choice of compensation design. Full disclosure of compensation practices was not required until the 1999 year, the first year of this sample. The lack of benchmarking available to firms through the financial statements and / or scrutiny by shareholders and analysts prior to 1999 could have resulted in less than efficient compensation practices, and this might be what is observed. If the lack of equity-based compensation in Australia is as a result of inefficient contracting, then there might be little or no consistently observable differences in firm characteristics across the firms choosing different compensation structures.

This Chapter adopts an efficient contracting perspective, and expects that on average, firms are using efficient compensation contracts, based on their underlying economic characteristics. Firms in the cash group use only cash-based compensation, and this tends to reflect the use of accounting-based performance measures only [Matolcsy (2000)], while the use of equity-based compensation by the firms in the equity group tends to suggest the use of equity-based performance measures as well. Thus firms in the equity group are using different performance measures compared to those in the cash 
group. As efficient contracting suggests that the use of these different performance measures is driven by firm characteristics [Bushman and Smith (2001)], it is expected that if the firms are using efficient compensation structures on average, the economic characteristics of the two compensation groups could be different. The economic characteristics expected to influence compensation structure choice are outlined above, and in summary, it is suggested that where firms are larger, have more growth options, are more decentralised, and have greater noise in the operating environment, it is relatively more difficult to monitor the managers through the accounting-based performance measures, and thus these firms might tend to use more equity-based performance measures and thus more equity-based compensation. Theory also suggests that where firms are more cash constrained, they could favour the use of equity-based compensation while where firms have greater CEO share ownership, the use of equitybased compensation might not be as relevant. Thus it is predicted that:

$H_{1}$ - On average, equity group firms are larger, have more growth options, are more decentralised, have greater noise in the operating environment, are more cash constrained, and have lower CEO share ownership compared to the cash group firms. 


\subsection{SAMPLE AND DATA}

\subsubsection{Sample selection}

The sample for this Chapter is the same as that used in Chapter Two, and the sample selection process is described in section 2.3 of Chapter Two.

\subsubsection{Research Design}

Section 3.3 summarises the theoretical discussion on the economic characteristics of the firm that are expected to influence the use of different performance measures in a compensation contract. Specifically, the theoretical literature cited discusses the firm characteristics that could lead to the use of equity-based performance measures and thus equity-based compensation, as opposed to the use of cash-based performance measures and thus cash-based compensation. As discussed in Section 3.3, the firm characteristics ${ }^{4}$ suggested to drive the use of equity- rather than cash-based compensation include firm size, growth options, decentralization, noise in the operating environment, cash constraints and CEO share ownership [empirical papers that have tested these firm characteristics include Ryan and Wiggins (2001), Core and Guay (2001) and Ittner, Lambert and Larcker (2003)].

Thus these firm characteristics could provide some explanation as to the choice of compensation structure made by firms, and this Chapter tests whether these characteristics differ in the cash group firms compared to the equity group firms. The 
measurement of the economic characteristics is described in Table 3.1 below. All variables are measured the year prior to that in which group membership is measured as they are expected to influence the compensation contract offered at the beginning of the period.

Table 3.1 - Economic characteristics of the firm important to compensation structure

\begin{tabular}{|l|l|l|l|}
\hline \multicolumn{1}{|c|}{ Variable } & \multicolumn{1}{|c|}{$\begin{array}{c}\text { Predicted } \\
\text { relation } \\
\text { (equity vs. cash) }\end{array}$} & \multicolumn{1}{|c|}{$\begin{array}{c}\text { Variable } \\
\text { name }\end{array}$} & \multicolumn{1}{|c|}{ Proxy used } \\
\hline Size & equity $>$ cash & Size $_{t-1}$ & $\begin{array}{l}\text { Log of the market value of } \\
\text { equity }\end{array}$ \\
\hline $\begin{array}{l}\text { Growth } \\
\text { opportunities }\end{array}$ & equity $>$ cash & MktBk $_{t-1}$ & Market-to-book ratio \\
\hline Decentralisation & equity $>$ cash & Decent $^{\text {sub }}{ }_{t-1}$ & $\begin{array}{l}\text { Log of number of } \\
\text { subsidiaries }\end{array}$ \\
\hline Decentralisation & equity $>$ cash & Decent $^{\text {subfor }}{ }_{t-1}$ & $\begin{array}{l}\text { Log of number of foreign } \\
\text { subsidiaries }\end{array}$ \\
\hline Noise & equity $>$ cash & Noise $_{t-x}$ & $\begin{array}{l}\text { Standard deviation of ROA } \\
\text { over prior 3 years }\end{array}$ \\
\hline Cash constraints & equity $<$ cash & Cash $_{t-1}$ & $\begin{array}{l}\text { Operating cash flow over } \\
\text { total assets }\end{array}$ \\
\hline $\begin{array}{l}\text { \%CEO share } \\
\text { ownership }\end{array}$ & equity $<$ cash & CEOown $_{t-1}$ & $\begin{array}{l}\text { Total common stock owned } \\
\text { by the CEO as a percentage } \\
\text { of total common stock } \\
\text { outstanding }\end{array}$ \\
\hline
\end{tabular}

In order to test whether the economic characteristics of the cash group are different to those of the equity group, univariate analysis is used to test for differences in the above economic characteristics of the firms between the cash and equity groups, where the dependent variable takes the value of 1 for the equity group and 2 for the cash group.

'Due to data limitations in measuring the CEO's risk preferences, no attempt is made to estimate differences across CEOs. 


\subsubsection{Firm characteristics and different types of equity-based compensation} Chapter Two provides evidence that there is much more variation in options granted by Australian firms compared to those granted by firms in the United States. The literature does not provide any explanations or links between firm characteristics and the use of different types of options (exercise prices, option terms and performance hurdles). Accordingly, this Chapter documents the differences in the firm characteristics for firms that offer different types of options based on those characteristics suggested to determine the use of equity-based compensation and described in Table 3.1 above. In addition, prior share returns and prior accounting performance are also investigated as possible determinants, as it could be possible that some of the choices made (such as the inclusion of hurdles) could be driven by past performance.

\subsection{RESULTS}

\subsubsection{Descriptive and Univariate results:}

Table 3.2 shows the overall sample distributions of the firm characteristics identified as being relevant to the level of CEO compensation for the total sample and for the cash and equity groups separately. Also shown are the statistical differences between the two

\footnotetext{
${ }^{5}$ Consistent with the measurement suggested by Bushman and Smith (2001).
} 
compensation groups. Due to missing data ${ }^{6}$, the overall sample is reduced to 672 observations, and 601 observations for the risk variable ${ }^{7}$.

'Missing data was from the 1998 year, where 2 firms had insufficient data to calculate the market value of equity, 2 firms ROA and the balance the market return for that year.

${ }^{7}$ All outliers are identified using the procedure in SPSS, and are winsorised. 
Table 3.2 - Sample distribution and statistical differences across groups, total sample:

\begin{tabular}{|c|c|c|c|c|c|c|c|c|c|c|c|c|c|c|}
\hline & \multicolumn{4}{|c|}{ Total sample } & \multicolumn{4}{|c|}{ Equity group } & \multicolumn{4}{|c|}{ Cash group } & \multicolumn{2}{|c|}{$\begin{array}{l}\text { Equity group vs. Cash } \\
\text { group }\end{array}$} \\
\hline & $\mathrm{n}$ & Mean & Median & Std dev & $\mathrm{n}$ & Mean & Median & Std dev & $\mathrm{n}$ & Mean & Median & Std dev & $\begin{array}{l}\mathrm{t} \text {-test } \\
(\mathrm{t})\end{array}$ & $\begin{array}{c}\text { Mann- } \\
\text { Whitney } \\
\text { U }\end{array}$ \\
\hline Size $_{t-1}$ & 672 & 19.306 & 18.972 & 1.670 & $\overline{441}$ & 19.514 & 19.204 & 1.782 & 231 & 18.908 & 18.661 & 1.385 & $4.480^{* * *}$ & $40944^{* * *}$ \\
\hline $\begin{array}{l}\text { Size } 1-\text { un- } \\
\text { logged }\end{array}$ & 672 & $1,445,976$ & 174,078 & $5,277,345$ & 441 & $1,934,230$ & 217,999 & $6,408,629$ & 231 & 513,855 & 127,038 & $1,162,330$ & $4.515^{* * *}$ & $40929^{* * *}$ \\
\hline $\mathrm{MktBk}_{\mathrm{r}-\mathrm{I}}$ & 672 & 3.148 & 1.762 & 5.223 & 441 & 3.501 & 1.904 & 6.121 & 231 & 2.473 & 1.623 & 2.64 & $3.182^{* * *}$ & $47093^{*}$ \\
\hline Decent $^{\text {sib }}{ }_{1-1}$ & 672 & 1.847 & 2.602 & 3.51 & $44 !$ & 2.044 & 2.708 & 3.367 & 231 & 1.472 & 2.303 & 3.568 & $1.993^{* *}$ & $41892^{* * *}$ \\
\hline $\begin{array}{l}\text { Decent }^{\text {sub }} \text { Bd- } \\
\text { un-logged }\end{array}$ & 672 & 33.975 & 13.475 & 56.33 & 441 & 39.652 & 15.030 & 63.684 & 231 & 23.136 & 9.974 & 36.319 & $4.278 * * 4$ & $41891^{* * *}$ \\
\hline Decent $_{t-1}^{\text {subior }}$ & 672 & -2.275 & .6932 & 5.477 & 441 & -1.528 & 1.099 & 5.371 & 231 & -3.715 & $\overline{0}$ & 5.403 & $4.994 * * *$ & $37989 * * *$ \\
\hline $\begin{array}{l}\text { Decent }{ }^{\text {subrot }} \\
\text { - un-logged }\end{array}$ & 672 & 10.815 & 1.994 & 27.886 & 441 & 14.125 & 3.004 & 32.964 & 231 & 4.497 & 1 & 11.351 & $5.538 * * *$ & $37990^{* * *}$ \\
\hline Noise $_{t-x}$ & 601 & .0603 & .0211 & .114 & 392 & .0592 & .020 & .114 & 209 & .062 & .024 & .115 & -0.305 & 40031 \\
\hline Cash $_{1-1}$ & 672 & .062 & .069 & .133 & 441 & .057 & .065 & .136 & 231 & .071 & .079 & .127 & -1.388 & $46548^{*}$ \\
\hline CEOown $n_{t-1}$ & 672 & .060 & .002 & .133 & 441 & .034 & .001 & .087 & 231 & .110 & .002 & .183 & $-7.31 * * *$ & $45003^{* * *}$ \\
\hline
\end{tabular}

*** significant at the 0.01 level (2-tailed) ** significant at the 0.05 level (2-tailed) "significant at the 0.10 level (2-tailed)

Where:

Size

Size, un-logged

Log of the market value of equity

$M k^{\prime} B k_{1-1}$

Market value of equity, rounded to the nearest \$'000

Decent ${ }^{206}$

Decent $^{\text {sub }}{ }_{1-1}-$ un-logged

Decent ${ }^{\text {subor }}{ }^{\prime \prime}{ }^{\prime \prime}$

Market-to-book ratio

Log of number of subsidiaries

Number of subsidiaries

Log of number of foreign subsidiaries

Number of foreign subsidiaries

Standard deviation of ROA over prior 3 years

Noise ${ }_{i \cdot x}$

Cash. $_{.1}$

$\%$ of operating cash flow over total assets

$\%$ of total common stock owned by the CEO over total common stock outstanding 
The univariate results in Table 3.2 show that firms with different characteristics choose different types of compensation structure, consistent with the theoretical literature. As predicted, the results show that equity-based compensation is used in those firms where monitoring is more difficult. That is, the equity firms are larger, more decentralised and have more growth options. The results on size and growth options are consistent with the United States' empirical results of Ryan and Wiggins (2001), Core and Guay (2001) and Ittner, Lambert and Larcker (2003), where the percentage of equity awarded is investigated. However none of the United States' studies investigated decentralisation. Further, the results also show that on average, the cash group has more cash compared to the equity group, consistent with the theoretical prediction that firms with less cash might tend to use more equity-based compensation, although this difference is only confirmed by the Mann-Whitney $U$ test. Ryan and Wiggins (2001), Core and Guay (2001) and Ittner, Lambert and Larcker (2003) all found cash constraints to be significant in relation to the amount of equity-based compensation used in their United States' samples.

CEO share ownership appears to be relatively high in some companies given the maximum figures. This could be partly due to estimation error as the total ownership of the CEO is disclosed, rather than the nominal and beneficial holdings disclosed separately ${ }^{8}$. However, as a nominal ownership implies that the CEO is the trustee of the shares, the CEO would still have incentives to act in the best interest for those shares

\footnotetext{
Under the Australian reporting requirements, only total shareholding need be disclosed, and the distinction between nominal and beneficial is not always made. A nominal shareholding is one in which shares are held in trust for another party, where the nominal
} 
and thus the agency problem can be reduced. Overall, CEO share ownership is higher in the cash group compared to the equity group, again consistent with the theory that the current ownership of the CEO is a consideration in the decision of whether or not to grant equity-based compensation', and consistent with Ryan and Wiggins' (2001) results ${ }^{10}$.

The existence of firms that provide no equity-based compensation in the Australian market could imply that these firms are not setting CEO compensation contracts in an efficient fashion, especially given the current body of CEO compensation evidence (predominantly from the United States) that equity-based compensation is widely used to remunerate the CEO. However, the use (or lack of use) of equity-based compensation is likely to be dependent on the underlying firm characteristics [Bushman and Smith (2001)]. The results in this Chapter provide strong evidence that on average, firms in the cash group have significantly different economic characteristics compared to firms in the equity group. This suggests that on average, firms that choose to provide equitybased compensation and those that do not could both be offering efficient contracts, based on their economic characteristics.

\subsubsection{Firm characteristics and different types of equity-based compensation:}

As stated above, there is no extant theory to predict the use of different option characteristics, and as such the following tests are exploratory in nature. In order to

holder may or may not have the voting rights, but does not have any rights to dividends or capital gains. A beneficial holding is one where the holder owns all rights associated with the shares.

Industry based results are reported in Appendix 3A 
determine whether differences in the types of equity-based compensation awarded are related to differences in the underlying firm characteristics, the following tests are performed:

i) Exercise price types and firm characteristics

ii) Option term types and firm characteristics

iii) Option hurdles and firm characteristics

\subsubsection{Exercise price types and firm characteristics}

First, the differences in firm characteristics across the three different exercise prices are investigated, and the results are reported in Table 3.3:

${ }^{10}$ Core and Guay (2001) and Ittner, Lambert and Larcker (2003) did not include CEO share ownership as a variable. 
TABLE 3.3 - FIRM CHARACTERISTICS AND EXERCISE PRICE TYPES:

\begin{tabular}{|c|c|c|c|c|c|c|c|c|c|}
\hline \multicolumn{10}{|c|}{ Panel A - Descriptive statistics } \\
\hline \multirow[t]{2}{*}{$\begin{array}{l}\text { Exercise } \\
\text { price: }\end{array}$} & \multicolumn{3}{|c|}{$\begin{array}{l}\text { Fair market value (FMV) } \\
\mathrm{N}=99\end{array}$} & \multicolumn{3}{|c|}{$\begin{array}{c}\text { Premium } \\
\mathrm{N}=53\end{array}$} & \multicolumn{3}{|c|}{$\begin{array}{c}\text { Discount } \\
\mathrm{N}=32\end{array}$} \\
\hline & Mean & Median & $\begin{array}{l}\text { Std } \\
\text { Dev }\end{array}$ & Mean & Median & $\begin{array}{l}\text { Std } \\
\text { Dev }\end{array}$ & Mean & Median & $\begin{array}{l}\text { Std } \\
\text { Dev }\end{array}$ \\
\hline Size $_{t-1}$ & 20.23 & 20.01 & 1.917 & 18.69 & 18.69 & 1.38 & 18.96 & 18.96 & 1.48 \\
\hline $\mathrm{MktBk}_{t-l}$ & 3.32 & 1.76 & 4.31 & 2.49 & 1.63 & 3.32 & 7.14 & 2.26 & 11.98 \\
\hline Decent $^{\text {sub }}{ }_{t-1}$ & 2.56 & 3.04 & 2.97 & 1.47 & 2.71 & 3.96 & 1.18 & 2.14 & 3.50 \\
\hline Decent $^{\text {subfor }}{ }_{t-1}$ & -.848 & 1.79 & 5.39 & -2.86 & 0 & 5.48 & -4.47 & -9.21 & 5.48 \\
\hline Noise $_{t-x}$ & .047 & .020 & .064 & .082 & .03 & .138 & .032 & .02 & .035 \\
\hline $\operatorname{Cash}_{t-1}$ & .045 & .05 & .112 & .035 & .05 & .108 & .053 & .09 & .182 \\
\hline CEOown $_{t-1}$ & .016 & 0 & .074 & .045 & .01 & .077 & .059 & 0 & .131 \\
\hline $\operatorname{Perf}^{S R}{ }_{t-1}$ & .422 & .100 & 1.524 & .827 & .02 & 2.36 & .57 & .075 & 1.96 \\
\hline $\operatorname{Perf}_{t-1}^{\mathrm{ROA}}$ & .022 & .040 & .147 & .028 & .02 & .157 & .038 & .05 & .173 \\
\hline
\end{tabular}

\begin{tabular}{|c|c|c|c|c|c|c|}
\hline \multicolumn{7}{|c|}{ Panel B - Differences across groups: } \\
\hline & \multicolumn{2}{|c|}{ FMV vs. premium } & \multicolumn{2}{|c|}{ FMV vs. discount } & \multicolumn{2}{|c|}{ Premium vs. discount } \\
\hline & $\begin{array}{l}\text { t-test } \\
(\mathrm{t})\end{array}$ & $\begin{array}{c}\text { Mann- } \\
\text { Whitney U }\end{array}$ & $\begin{array}{l}\text { t-test } \\
(\mathrm{t})\end{array}$ & $\begin{array}{c}\text { Mann- } \\
\text { Whitney U }\end{array}$ & $\begin{array}{l}\text { t-test } \\
(t)\end{array}$ & $\begin{array}{c}\text { Mann- } \\
\text { Whitney U }\end{array}$ \\
\hline Size $_{t-1}$ & $5.168 * * *$ & $1381.5^{* * *}$ & $3.427 * * *$ & $957.5^{* * *}$ & .845 & 740.5 \\
\hline $\mathrm{MktBk}_{\mathrm{f}-\mathrm{I}}$ & 1.223 & 2356 & $-2.690 * * *$ & 1296.5 & $2.668^{* * *}$ & $584.5^{* *}$ \\
\hline $\operatorname{Decent}^{\mathrm{sub}}{ }_{t-l}$ & $1.919^{*}$ & $2105^{* *}$ & $2.188^{* *}$ & $922^{* * *}$ & -.340 & 6675 \\
\hline Decent $^{\text {subfor }}$ & $2.18^{* *}$ & $1883 * * *$ & $3.291^{* * *}$ & $931^{* * *}$ & -1.314 & 721 \\
\hline Noise $_{t-x}$ & $-2.028 * *$ & 1660 & 1.215 & 1278 & $-1.921^{*}$ & 516.5 \\
\hline Cash $_{1-1}$ & .532 & 2501.5 & -.288 & $1214^{* *}$ & .567 & $632.5^{* *}$ \\
\hline CEOown $_{t-1}$ & $-2.261 * *$ & $1685^{* * *}$ & $-2.362 * *$ & $1163 * * *$ & .661 & 797 \\
\hline $\operatorname{Perf}_{t-I}^{6 R}$ & -1.282 & 2591 & -.446 & 1546.5 & -.516 & 818 \\
\hline $\operatorname{Perf}^{\mathrm{ROA}}{ }_{t-1}$ & -.195 & 2468.5 & -.503 & 1421 & .292 & 744.5 \\
\hline
\end{tabular}

*** significant at the 0.01 level (2-tailed) ** significant at the 0.05 level (2-tailed) * significant at the 0.10 level (2-tailed) Where:

Size,

$\mathrm{MktBk}_{r t}$

Decent ${ }^{\text {tub }}$

Decent ${ }^{\text {sublor }}$,

Log of the market value of equity

Noise $1 . x$

Cash $_{t-1}$

CEOown,-1

Perf ${ }^{6 R-1}$

Market-to-book ratio

Log of number of subsidiaries

Log of number of foreign subsidiaries

Standard deviation of ROA over prior 3 years

Operating cash flow over total assets.

Total common stock owned by the CEO as a percentage of total common stock outstanding

Prior year share return

Prior year Return on Assets (ROA), measured as EBIT divided by the average book value of assets 
Panel A of Table 3.3 provides the descriptive statistics, and reveals that the firm characteristics differ across firms using the different exercise price types. Fair market value (FMV) firms ${ }^{11}$ tend to be larger and more decentralised than both the "discount" 12 and 'premium' 13 firms, but also appear to have lower CEO ownership. The discount firms appear to have a higher level of growth options compared to the other two groups, while the premium firms have better prior share returns.

Panel B of Table 3.3 compares the differences across the groups, and indicates that there are some significant differences in the economic characteristics of firms offering different option exercise price types. Firms offering options at FMV are significantly larger than firms offering discount and premium options, which could indicate that larger firms are more likely to follow the lead of the United States. Compared to the FMV firms, premium firms have more risk in the operating environment and the CEO has a higher share ownership (both at the $5 \%$ level). This could indicate that in these firms, premium options are being awarded to provide even greater incentive to the CEO.

One reason for issuing discount options might be to reward the CEO for past performance, although there are no significant differences in the past performance measures between the three groups. Discount options might also be awarded to control for some extreme levels of risk aversion in the CEOs, and this could be the reason that growth options are significantly higher in the discount group compared to both the FMV

\footnotetext{
"Exercise price equal to market price on date of issue

12 Exercise price less than market price on date of issue

${ }^{13}$ Exercise price greater than market price on date of issue
} 
and premium groups. However, this would only be the case if growth options proxied in some way for the risk of the firm. Finally, discount options could be an indication of agency problems and that the CEO is setting his or her own remuneration. As option packages are accepted by vote by shareholders, a CEO might be able to influence the option package if he or she had sufficient share holding to do so. The results provide weak evidence that the discount CEOs own more shares that the FMV CEOs, although with a mean holding of $5.9 \%$ the ownership does not seem sufficient to be able to vote in a more beneficial option package at the annual general meeting where a $50 \%$ vote is required. However, with only 32 discount firms, these results should be interpreted with care.

\subsubsection{Option term types and firm characteristics}

Differences in firm characteristics across the different option terms are also investigated, and the results are reported in Table 3.4: 
TABLE 3.4 - FIRM CHARACTERISTICS AND OPTION TERMS:

\begin{tabular}{|c|c|c|c|c|c|c|c|c|c|c|c|c|}
\hline \multicolumn{13}{|c|}{ ptive statistics } \\
\hline \multirow[t]{2}{*}{ Option term: } & \multicolumn{3}{|c|}{$\begin{array}{c}<5 \text { years } \\
N=54\end{array}$} & \multicolumn{3}{|c|}{$\begin{array}{c}=5 \text { years } \\
N=107\end{array}$} & \multicolumn{3}{|c|}{$\begin{array}{c}=10 \text { years } \\
n=10\end{array}$} & \multicolumn{3}{|c|}{$\begin{array}{c}>10 \text { years } \\
\mathrm{N}=32\end{array}$} \\
\hline & Mean & Median & $\begin{array}{l}\text { Std } \\
\text { Dev }\end{array}$ & Mean & Median & $\begin{array}{l}\text { Std } \\
\text { Dev }\end{array}$ & Mean & Median & $\begin{array}{l}\text { Std } \\
\text { Dev }\end{array}$ & Mean & Median & $\begin{array}{l}\text { Std } \\
\text { Dev }\end{array}$ \\
\hline Size $_{t-1}$ & 19.219 & 19.035 & 1.993 & 19.480 & 19.36 & 1.647 & 20.71 & 20.81 & 1.367 & 20.796 & 21.710 & 2.390 \\
\hline $\mathrm{MktBk}_{t-1}$ & 3.373 & 1.945 & 6.853 & 4.06 & 1.59 & 6.51 & 1.977 & 1.600 & .912 & 4.058 & 2.130 & 4.768 \\
\hline Decent ${ }^{\text {sub }}$ & 2.372 & 2.740 & 2.536 & 1.854 & 2.71 & 3.533 & 2.143 & 3.225 & 4.170 & 1.659 & 3.56 & 4.937 \\
\hline Decent ${ }^{\text {subfor }}{ }_{t-1}$ & -2.700 & .0 & 5.536 & -2.208 & 1.100 & 5.625 & .495 & 2.505 & 5.276 &. .113 & 2.20 & 5.323 \\
\hline Noise $_{t-x}$ & .072 & .030 & .126 & .044 & .020 & .065 & .043 & .015 & .058 & .072 & .02 & .098 \\
\hline Cash $_{t-1}$ & .029 & .050 & .167 & .047 & .060 & .109 & .660 & .065 & .067 & .064 & .080 & .085 \\
\hline CEOown $_{l-1}$ & .034 & .0 & .070 & .034 & .0 & .104 & .015 & .0 & .047 & .012 & .0 & .042 \\
\hline $\operatorname{Perf}_{t-1}^{S R}$ & .562 & -.025 & 2.08 & .484 & .080 & 1.580 & 1.357 & -.035 & 3.664 & .619 & .220 & 1.275 \\
\hline $\operatorname{Perf}_{R O A}{ }_{1-1}$ & .063 & .010 & .144 & .013 & .040 & .150 & -.035 & .040 & .249 & .044 & .040 & .124 \\
\hline
\end{tabular}




\begin{tabular}{|c|c|c|c|c|c|c|}
\hline \multicolumn{7}{|c|}{ Panel B - Differences across groups: } \\
\hline & \multicolumn{2}{|c|}{$<5$ years vs. $=5$ years } & \multicolumn{2}{|c|}{$<5$ years vs. $=10$ years } & \multicolumn{2}{|c|}{$<5$ years vs. $>10$ years } \\
\hline & $\begin{array}{l}\text { t-test } \\
(\mathrm{t})\end{array}$ & $\begin{array}{c}\text { Mann- } \\
\text { Whitney U }\end{array}$ & $\begin{array}{c}\text { t-test } \\
(t)\end{array}$ & $\begin{array}{c}\text { Mann- } \\
\text { Whitney } \mathbf{U}\end{array}$ & $\begin{array}{l}\text { t-test } \\
(t)\end{array}$ & $\begin{array}{c}\text { Mann- } \\
\text { Whitney U }\end{array}$ \\
\hline$\overline{\text { Size }_{1-1}}$ & -.882 & 2502 & $-2.258^{* *}$ & $128^{* * *}$ & $-2.46^{* *}$ & $212^{* *}$ \\
\hline $\mathrm{MktBk}_{t-l}$ & -.622 & 2762 & .639 & 262 & -.340 & 258 \\
\hline Decent $^{\text {sub }}{ }_{1-1}$ & .958 & 2778 & .235 & 227 & .740 & 294 \\
\hline Decent $^{\text {subfor }}{ }_{1-1}$ & -.526 & 2640 & $-1.687^{*}$ & $156^{* *}$ & -1.523 & $233^{*}$ \\
\hline Noise $_{1-x}$ & $1.729^{*}$ & 1608 & .696 & 183 & 0 & 276 \\
\hline $\operatorname{Cash}_{t-1}$ & -.818 & 2852 & -.691 & 249 & -.731 & 310 \\
\hline CEOown $_{t-1}$ & -.020 & 2525 & .820 & $190^{*}$ & 1.107 & $237^{* *}$ \\
\hline $\operatorname{Perf}_{t-1}$ & .265 & 2720 & -.970 & 241 & -.093 & 248 \\
\hline \multirow[t]{3}{*}{ Perf $^{\text {ROA }}{ }_{1-1}$} & $2.027^{* *}$ & 2714 & $1.733^{*}$ & 269 & .432 & 337 \\
\hline & \multicolumn{2}{|c|}{$=5$ years vs. $=10$ years } & \multicolumn{2}{|c|}{$=5$ years vs. $>10$ years } & \multicolumn{2}{|c|}{$=10$ years vs. $>10$ years } \\
\hline & $\begin{array}{c}\text { t-test } \\
(t)\end{array}$ & $\begin{array}{c}\text { Mann- } \\
\text { Whitney U }\end{array}$ & $\begin{array}{c}\text { t-test } \\
(t)\end{array}$ & $\begin{array}{c}\text { Mann- } \\
\text { Whitney } \mathbf{U}\end{array}$ & $\begin{array}{l}\text { t-test } \\
(\mathrm{t})\end{array}$ & $\begin{array}{c}\text { Mann- } \\
\text { Whitney U }\end{array}$ \\
\hline Size $_{t-1}$ & $-2.283^{* *}$ & $298^{* *}$ & $-2.581^{* *}$ & $225^{* *}$ & -.104 & 57 \\
\hline $\mathrm{MktBk}_{\ell-l}$ & 1.007 & 508 & .002 & 502 & -1.354 & 37 \\
\hline $\operatorname{Decent}^{\text {sub }}{ }_{1-1}$ & -.243 & 428 & .180 & 556 & .249 & 64 \\
\hline Decent $^{\text {subfor }}{ }_{t-1}$ & -1.460 & $346^{*}$ & -1.275 & 526 & .273 & 56 \\
\hline Noise $_{t-x}$ & .034 & 469 & -1.357 & 521 & -.814 & 55 \\
\hline Cash $_{t-1}$ & -.544 & 490 & -.541 & 612 & .066 & 57 \\
\hline CEOown $_{t-1}$ & .579 & 442 & .779 & 556 & .186 & 63 \\
\hline $\operatorname{Perf}_{l-l}^{S R}$ & -1.442 & 459 & -.294 & 557 & .679 & 44 \\
\hline $\operatorname{Perf}_{l-1}^{\mathrm{ROA}}$ & .901 & 522 & -.722 & 653 & -.994 & 64 \\
\hline 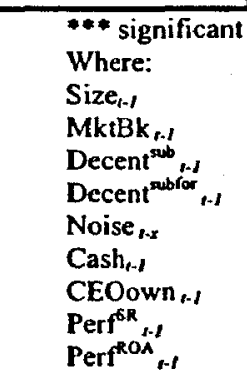 & the 0.01 level & \multicolumn{5}{|c|}{$\begin{array}{l}\text { Log of the market value of equity } \\
\text { Market-to-book ratio } \\
\text { Log of number of subsidiaries } \\
\text { Log of number of foreign subsidiaries } \\
\text { Standard deviation of ROA over prior } 3 \text { years } \\
\text { Operating cash flow over total assets } \\
\text { Total common stock owned by the CEO as a percentage of total common stock outstanding } \\
\text { Prior year share retum } \\
\text { Prior year Return on Assets (ROA), measured as EBIT divided by the average book value of assets }\end{array}$} \\
\hline
\end{tabular}


Panel A of Table 3.4 indicates some variation across the groups. Growth options appear larger in the $=5$ years and $>10$ years compared to the other two groups, while the $=10$ years group has the highest cash, and CEO ownership is highest in the $<5$ years and $=5$ years groups. Prior year share returns is high in all groups, and this could indicate that equity grants are made following good market performance.

Panel B shows no significant differences at the $1 \%$ level in economic determinants across the groups of firms. However, again the groups are relatively small, with the largest being firms that offer options of 5 years. As discussed in Chapter Two, until 1 July 1999 firms were prohibited under Australian law to offer options with terms greater than 5 years, which would explain the small samples of firms offering options of greater than five years. Significant at the $5 \%$ level is that those firms offering longer termed options are larger, which could indicate that our larger firms have followed the lead of the United States on option terms as well as on exercise prices as discussed above. As a sensitivity, the firms in the $=10$ years and $>10$ years groups were combined into one group and the differences re-examined. With the firms combined, the significance on the differences in firm size is at $1 \%$, and the $=$ and $>10$ year firms have significantly more foreign subsidiaries to the $<5$ year group only, at the $5 \%$ level. No other significant differences are noted. 


\subsubsection{Option hurdles and firm characteristics}

Finally, firm characteristics and the incidence of option hurdles are investigated, and the results are provided in Table 3.5:

TABLE 3.5 - Firm Characteristics ANd Option HuRdLes:

\begin{tabular}{|c|c|c|c|c|c|c|}
\hline \multicolumn{7}{|c|}{ Panel A - Descriptive statistics } \\
\hline \multirow[t]{2}{*}{$\begin{array}{l}\text { Option } \\
\text { hurdles: }\end{array}$} & \multicolumn{3}{|c|}{$\begin{array}{l}\text { Without hurdles } \\
\qquad N=118\end{array}$} & \multicolumn{3}{|c|}{$\begin{array}{c}\text { With hurdles } \\
\qquad N=66\end{array}$} \\
\hline & Mean & Median & $\begin{array}{l}\text { Std } \\
\text { Dev }\end{array}$ & Mean & Median & $\begin{array}{l}\text { Std } \\
\text { Dev }\end{array}$ \\
\hline Size $_{1-1}$ & 19.006 & 18.85 & 1.720 & 20.557 & 20.24 & 1.64 \\
\hline $\mathrm{MktBk}_{t-l}$ & 4.095 & 1.795 & 6.468 & 3.121 & 1.705 & 6.048 \\
\hline Decent $_{t-1}^{\text {sub }}$ & 1.735 & 2.675 & 3.478 & 2.497 & 3.066 & 3.246 \\
\hline Decent $^{\text {subfor }}{ }_{t-l}$ & -2.435 & .690 & 5.420 & -1.383 & 2.015 & 5.849 \\
\hline Noise $_{t-x}$ & .0562 & .020 & .097 & .049 & .020 & .072 \\
\hline Cash $_{t-1}$ & .038 & .050 & .135 & .054 & .070 & .108 \\
\hline CEOown $_{t-1}$ & .042 & .0 & .106 & .012 & .0 & .036 \\
\hline $\operatorname{Perf}^{6 \mathrm{R}}{ }_{t-1}$ & .607 & .105 & 1.830 & .487 & .020 & 1.958 \\
\hline $\operatorname{Perf}_{t-1}^{\text {ROA }}$ & .009 & .020 & .174 & .058 & .040 & .105 \\
\hline
\end{tabular}




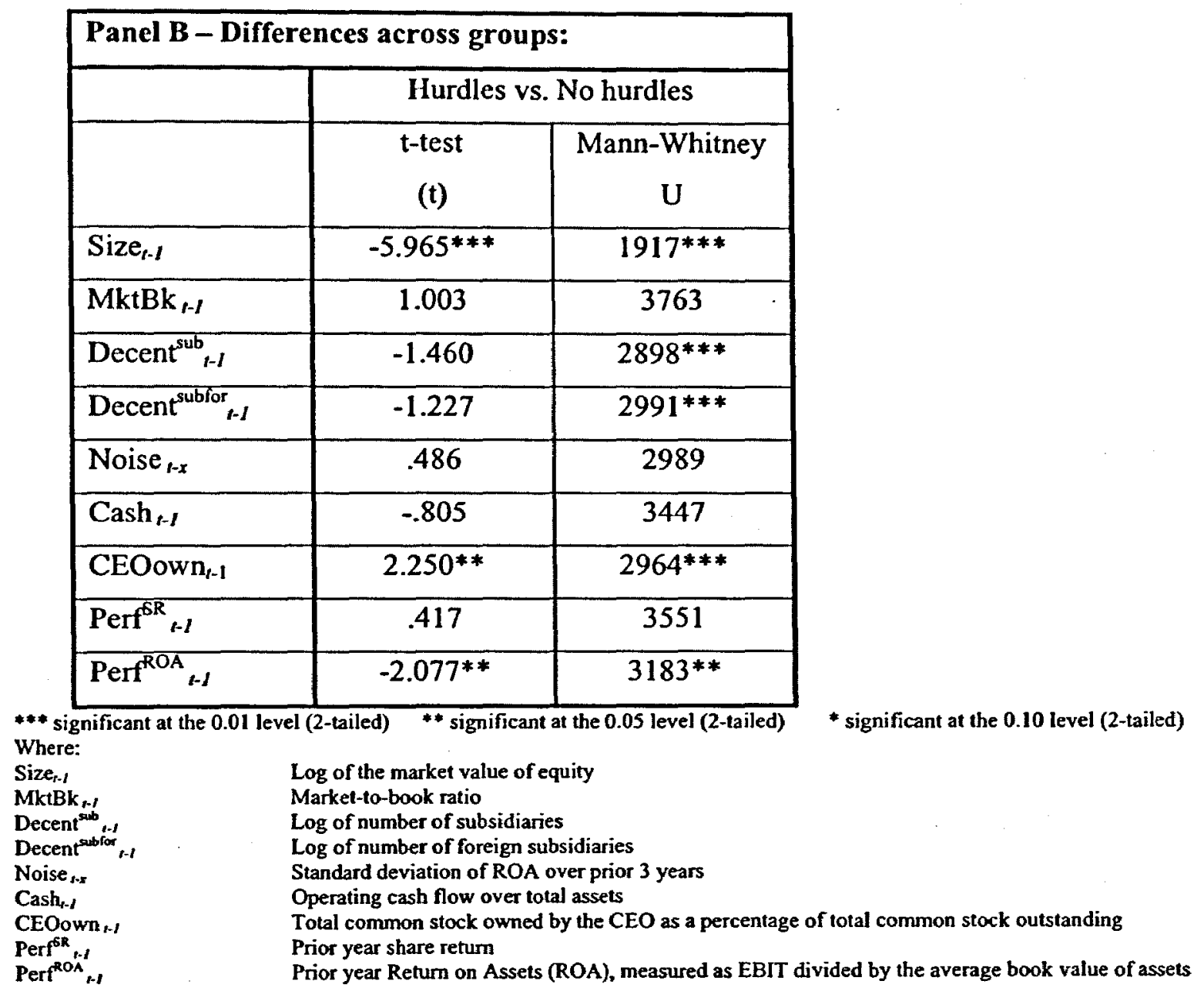

Panel A of Table 3.5 shows that firms using hurdles tend to be larger, more decentralised, have better prior accounting performance but have lower growth options, CEO share ownership and prior market performance. Panel B reveals that firms including hurdles in their options are significantly larger than those that do not, which is interesting in that the larger firms appear to have been following the option granting practices of United States' firms in the other two areas investigated. CEO ownership is higher in firms not providing hurdles, which could indicate some CEO influence. 
Finally, prior ROA is higher in the firms with hurdles, which is interesting as many hurdles are written in terms of accounting performance.

\subsection{IMPLICATIONS OF FINDINGS}

This Chapter investigates the relation between firms' economic characteristics and the use of the two different types of CEO compensation structures - cash only (the cash group) and cash and equity (the equity group). The variation in compensation structure observed in the Australian market could imply that the cash group firms are using inefficient contracts, especially given the body of evidence that suggests that equitybased compensation is routinely offered to CEOs in the United States. Alternatively, Australian firms (on average) could be making efficient compensation choices.

Efficient contracting suggests that compensation contracting (both levels and structure) is set based on the underlying economic characteristics of the firm [Core, Holthausen and Larcker (1999), Bushman and Smith (2001), Ittner, Lambert and Larcker (2003)]. As the cash group offers a significantly different compensation structure compared to the equity group, these arguments could suggest that the economic characteristics of the firms in the two groups are different as well. Chapter Three compares the economic characteristics of the firms in the two groups, and finds that the economic characteristics of the equity group firms are significantly different to those of the cash group firms. The key differences between the groups are that the equity firms tend to be larger, have 
more growth options, are more complex, have less cash and have lower CEO shareholding compared to the cash firms.

The implications of these findings are analysed further in the following Chapter by investigating the performance consequences of the use of the different types of compensation structures. First, Chapter Four provides evidence on whether or not there are differences in firm performance across the two compensation structures. Second, Chapter Four models an efficient contract, and the performance consequences of firms deviating from the predicted group based on their economic characteristics is determined. Chapter Five contains the conclusions of the thesis. 


\section{CHAPTER 4 \\ THE RELATION BETWEEN CEO COMPENSATION STRUCTURE AND FIRM \\ PERFORMANCE}

\section{I. INTRODUCTION}

The relation between CEO pay and firm performance has been extensively documented in the academic literature [for example, Jensen and Murphy (1990), Gibbons and Murphy (1990), Mehran (1995), Murphy (1999), Core and Guay (1999), Hermalin and Wallace (2001), Frye (2001), Sesil et al (2001), Ryan and Wiggins (2001), Ittner, Lambert and Larcker (2003)]. However, these studies have concentrated on a data set in which equity-based compensation is routinely offered to the CEO.

Chapter Two' shows that Australia offers a new environment in which to study CEO compensation, as it is a market in which CEOs are not necessarily provided equity-based compensation. However, despite the opportunities afforded by the Australian market, as well as widespread attention from the Australian business community to CEO compensation, there is only very limited evidence on the relation between CEO compensation and firm performance in the Australian setting. The studies conducted in Australia are limited to those by Defina, Harris and Ramsay (1994), Izan, Sidhu and Taylor (1998), and Matolcsy (2000), all of which do not address the differences in the

\footnotetext{
${ }^{1}$ Chapter Two provides evidence that unlike the relatively homogeneous CEO compensation design documented by Murphy (1999) in the United States, there is variation in Australian CEO compensation contract design, in that around one third of the CEOs of Australia's largest firms receive no equity-based compensation. Specifically. Chapter Two finds that two distinct types of CEO
} 
compensation structures awarded to the CEO, use the pre 1998 banded compensation disclosures, small samples and largely ignore the differences in firm characteristics and compensation contract choice. This Chapter provides the first detailed evidence of the links between firm performance and CEO compensation structure in a market in which equity-based compensation is not always offered to the CEO.

There are two objectives of this Chapter. First, the Chapter provides evidence on the relation between firm performance and CEO compensation structure [cash versus equity]. The Chapter looks at two possible alternative theories for the relation between compensation structure and firm performance. On one hand, many studies have argued that management's incentives are more closely aligned with those of shareholders when management receive some sort of equity-based compensation [Holmstrom (1979), Harris and Raviv (1979), Grossman and Hart (1983), Smith and Watts (1982), Smith and Stultz (1985), Hirshleifer and Suh (1992) and Shleifer and Vishney (1997)]. Given these arguments, firm performance could be expected to be better in the firms that award equity-based compensation.

On the other hand, compensation structure could be set dependent on the underlying economic characteristics of the firm [Demsetz and Lehn (1985), Lambert and Larcker (1987), Banker and Datar (1989), Smith and Watts (1992), Gaver and Gaver (1993), Core, Holthausen and Larcker (1999), Datar, Kulp and Lambert (2001), Bushman and 
Smith (2001)]. These studies imply that it might not be efficient for all firms to provide equity-based compensation. If the compensation structures are set dependent on firm characteristics, then variation in compensation structure would be observed, but as this variation is efficient, there would be no cross-sectional differences in firm performance [Core, Holthausen and Larcker (1999), Ittner, Lambert and Larcker (2003)]. Chapter Three shows that the variation in compensation structure observed in the Australian market is associated with differences in the underlying economic characteristics of the firms as predicted by theory, thus providing some evidence that these choices are as a result of efficient contracting. These findings are further developed in this Chapter, where the association between choice of whether or not to use equity-based compensation and firm performance is investigated, a question that has not been addressed in the literature to date.

The second objective of this Chapter is to build a model that describes the 'efficient ${ }^{2}$ compensation structure based on firm characteristics, and to determine the performance consequences of deviations from the efficient contract. The prediction for this section is that firms using sub-efficient CEO compensation structures would have lower firm performance compared to those that use an efficient structure [Ittner, Lambert and Larcker (2003)]. This Chapter represents the first study to build a model that recognises that it could be efficient to have no equity-based compensation in the CEO's compensation package.

\footnotetext{
2 An 'efficient' contract is one in which agency costs are minimised [Jensen and Meckling (1976), and is determined by the underlying economic characteristics of the firm. As noted in Chapter Three, the preferences of the CEO are not considered in this thesis, due to issues in establishing a satisfactory proxy.
} 
There are three motivations for this Chapter. First, while studies have looked at both the links between components of compensation and firm performance (and have mixed results) [Jensen and Murphy (1990), Murphy (1999), Mehran (1995), Frye (2001), Sesil, Kroumova, Kruse and Blasi (2001)] and efficient compensation contracting [Ryan and Wiggins (2001), Ittner, Lambert and Larcker (2003)], these studies have all been conducted in the United States' market where CEOs are uniformly awarded some level of equity-based compensation [Murphy (1999)]. Consequently, there has been no study to date to look at the performance consequences of compensation contracts in which there is no equity awarded at all.

However, the theoretical literature predicts that differences in firm characteristics could lead to differences in the CEO compensation structure, [Demsetz and Lehn (1985), Smith and Watts (1992), Gaver and Gaver (1993), Core, Holthausen and Larcker (1999)] and that it can be efficient for some firms not to award equity-based compensation [Bushman and Smith (2001)]. By using the Australian setting, compensation structure and firm performance can be studied in an environment where some firms choose not to provide any equity-based compensation at all. Consequently, this Chapter provides the first evidence on whether or not different compensation structures are associated with different firm performance.

The second motivation is to expand on the limited evidence on Australian CEO compensation and its relation to firm performance. The pay-performance relation has 
received some limited attention in Australia, for example Defina, Harris and Ramsay (1994) and Izan, Sidhu and Taylor (1998), but neither study finds any evidence of a relation between changes in CEO pay and changes in contemporaneous firm performance. Matolcsy (2000) also investigates the Australian pay-performance relation, and shows that the pay-performance relation is not stable over time, and is a function of specific economic cycles. Nevertheless, these studies all use compensation data from years prior to 1998 which was limited ${ }^{3}$, and consequently these early studies use a relatively noisy measure of the CEO's remuneration. Further, there are no Australian studies to date that investigate the link between firm performance and compensation structure, nor that investigate the efficient compensation structure. This Chapter investigates both whether there are any systematic differences in firm performance across firms that offer different compensation structures, as well as investigating the performance consequences of deviations from the predicted compensation structure, thus providing important evidence to assist in the current regulatory and popular press debate.

The third motivation for this Chapter is to improve on the empirical specifications used to date in this area of research. First, this Chapter focuses on "old" economy firms", rather than the "new" economy firms used in similar United States' studies to dates: Research investigating new economy firms has had to focus on market-based returns as

\footnotetext{
${ }^{3}$ The data provides the number of executives receiving cash compensation within bandwidths of $\$ 10,000$, beginning at $\$ 100,000$, and summarised information on the conditions of the equity-based compensation awarded to executives.

- This Chapter uses the same data used in Chapters Two and Three, and so focuses on large Australian firms across a range of industries including established industries such as mining and manufacturing.

"Itner, Lambert and Larcker (2003) provide analysis on "new" economy firms, which they define as firms operating in the computer, software, internet, telecommunications or networking industries.
} 
the performance measure, as these firms on average do not yet have any accounting income [Ittner, Lambert and Larcker (2003)]. The inherent disadvantage of using market based performance measures is that the measure could already fully reflect the economic consequences of sub-efficient contracting ${ }^{6}$. By focusing on "old" economy firms, this Chapter uses accounting-based performance measures as well as marketbased performance measures.

The evidence of this Chapter is based on the same sample as that used in Chapters Two and Three - a sample of large Australian firms for the period 1999-2001, and consists of 696 firm years. All accounting and compensation related data are available from the "UTS-Accenture Who Governs Australia" database, while stock price information is taken from SIRCA ${ }^{7}$, and firm betas from Commsec ${ }^{8}$. The analyses first indicate that on average, there is no systematic difference in firm performance between the firms that offer equity-based compensation and those that do not. This is consistent with the notion that on average, economic characteristics of the firm drive compensation structure. However, when the predictive model is used, and firms deviating from the efficient structure are identified, there is some evidence that the performance of firms deviating from the efficient structure is poorer than firms that do not.

The remainder of the Chapter is organised as follows. Section 4.2 reviews the literature on the pay-performance relation in both the United States and Australia and the efficient

\footnotetext{
${ }^{6}$ That is, that the market prices have already adjusted to reflect the costs of the incorrect compensation contract awarded.

${ }^{7}$ Securities Industry Research Centre of Asia-Pacific

- Commonwealth Securities Limited
} 
contacting research from the United States, while section 4.3 develops the theory. Section 4.4 describes the data used in the Chapter and outlines the research design. Section 4.5 reports the results of the Chapter, and the conclusions of the Chapter are contained in section 4.6.

\subsection{LITERATURE REVIEW}

\subsubsection{Evidence using changes in compensation and changes in performance} Jensen and Murphy (1990) examine the sensitivity of the United States' CEO compensation to firm performance. Using 1,049 firms and 1,688 CEOs for the years 1974 to $1986^{9}$, Jensen and Murphy (1990) estimate the pay-performance relation provided by performance-based bonuses and salary revisions, stock options and performance-based dismissal decisions. Jensen and Murphy (1990) find that a $\$ 1,000$ increase in shareholder wealth leads to an average increase in the CEO's total compensation of around $\$ 3.25^{10}$. Jensen and Murphy (1990) argue that while this result is statistically significant, economically the sensitivity is too low to offer adequate management incentives, and interpret this finding as evidence of inefficient compensation arrangements, potentially driven by politically motivated restrictions on very high levels of pay. Jensen and Murphy (1990) also find that most of the payperformance sensitivity comes from CEOs holding their firm's stock, but that such holdings are relatively small, and are declining. Finally, Jensen and Murphy (1990) find

\footnotetext{
9 All monetary variables are inflation adjusted and reported in constant 1986 dollars.

${ }^{10}$ Jensen and Murphy (1990) atso report that the pay-performance sensitivities in the 1930s were around 10 times larger than those in the 1970 s and 1980 s
} 
a weaker relation between pay and performance in the larger firms compared to the smaller firms in their sample [sensitivity of $\$ 1.85$ per $\$ 1,000$ for the top half of the sample compared to $\$ 8.05$ per $\$ 1,000$ for the bottom half of the sample].

Gibbons and Murphy (1990) also look at the pay-performance relation of United States' CEO compensation by investigating the incidence of relative performance evaluation $(\mathrm{RPE})^{11}$ in the compensation contracts of 1,668 CEOs from 1,049 firms from 1974 to 1986 [the same sample used by Jensen and Murphy (1990)]. Measuring performance as the rate of return on common stock, Gibbons and Murphy (1990) find that the median pay-performance relation equates to a less than 9 cent pay increase for every $\$ 1,000$ increase in shareholder wealth. Consistent with Jensen and Murphy (1990), Gibbons and Murphy (1990) state that while this result is statistically significant, its economic magnitude is small ${ }^{12}$. Gibbons and Murphy (1990) also find evidence that firms use relative performance rather than total performance in the revision of cash compensation contracts and retention decisions, and that CEO performance is more likely to be measured relative to aggregate market movements than to industry movements ${ }^{13}$. Murphy (1999) also describes the cash pay performance sensitivities for United States' CEOs. Using the S\&P 500 from 1971 to 1996 , and measuring the changes in cash pay

\footnotetext{
"That is, rather than looking at firm performance in isolation, the firm's performance relative to some benchmark (such as industry peers) is measured and the impact on compensation determined.

12 The difference between the pay-performance results of Gibbons and Murphy (1990) and Jensen and Murphy (1990) is not discussed in either paper. However, the difference is potentially due to the measurement of CEO compensation used, as Jensen and Murphy (1990) include change in the value of CEO stock and option ownership as part of the change in CEO compensation while Gibbons and Murphy (1990) do not.

${ }^{13}$ However, while Gibbons and Murphy (1990) find some evidence of the existence of RPE, Barro and Barro (1990), Janakiraman, Lambert and Larcker (1992) and Aggrawal and Samwick (1999) find little evidence of RPE
} 
(salary plus bonus and other cash pay) on the change in shareholder wealth, Murphy (1999) shows that the cash salary pay-performance relation has nearly tripled from the

1970s to the 1990s. Murphy (1999) also investigates the total pay-performance relation, using the S\&P 500 yearly and by industry from 1992 to 1996 , and measures the change in total CEO wealth (cash salary, plus the change in value of stock, restricted stock and options) on the change in shareholder wealth. Murphy (1999) finds that the total payperformance relation is driven primarily by stock options and share ownership [consistent with the findings of Jensen and Murphy (1990)]. He also demonstrates that the pay-performance relation varies across different industries, and is lowest in the regulated industries [utilities]. Murphy (1999) also finds that over all industries, the pay-performance relation has increased from 1992 to 1996, primarily due to stock option grants. Finally, looking only at the industrial firms, Murphy (1999) shows that the pay-performance relation is smaller in the larger firms [again consistent with the findings of Jensen and Murphy (1990)], but that the increase seen in the payperformance relation from 1992 to 1996 is due to increases in the pay-performance relations in the larger rather than mid-size and smaller firms.

\subsubsection{Evidence using levels of compensation and performance}

Jensen and Murphy (1990), Gibbons and Murphy (1990) and Murphy (1999) all test the pay-performance relation using changes in CEO compensation on change in shareholder wealth (or other performance measures). Hermalin and Wallace (2001) test the pay- 
performance relation of CEO compensation using the level of total CEO compensation, rather than the change in total CEO compensation.

Hermalin and Wallace (2001) argue that one limitation of the pay-performance literature to date is that the heterogeneity in the economic characteristics of firms has been largely ignored, and all firms have been treated as homogeneous in their choice of compensation contracts in the statistical tests conducted. As a result, the estimates of the pay-performance relation reflect only the weighted average contract terms. Hermalin and Wallace (2001) restrict their sample to a single industry to control for some of the inter-firm heterogeneity, and test the pay-performance relation using a sample of 104 publicly traded savings and loans (thrifts) from 1988 to 1993 . In their statistical estimation, Hermalin and Wallace (2001) use five different firm characteristics that they suggest could influence the choice of compensation contract (and thus the expected pay-performance relation) within the firms - thrift size, capitalisation, risk in the performance measures, CEO ability and CEO stock ownership. Measuring performance as both return on assets and percentage change in stock price, Hermalin and Wallace (2001) find that both performance measures are positive and significant, implying that the thrift firms reward the CEO for both accounting and stock price performance. Hermalin and Wallace (2001) also demonstrate that the thrifts make trade-offs in how they weight accounting and stock price performance measures in CEO compensation, based on the underlying economic characteristics of the firm. Hermalin and Wallace (2001) conclude that by controlling for differences in firm characteristics, a more efficient estimate of the pay-performance relation is obtained. 


\subsubsection{Evidence on the relation between different components of compensation and firm performance}

Empirical evidence from the United States suggests that the pay-performance relation is driven primarily by stock options and stock ownership [Jensen and Murphy (1990), Murphy (1999)], and that the increase in the pay-performance sensitivities observed in the United States' market has been driven primarily by stock option grants [Murphy (1999)].

Other empirical studies attempt to describe the links between the structure of compensation and firm performance, and provide mixed evidence. For example, Mehran (1995) investigates the relation between executive compensation and firm performance using US data from $1979 / 80^{14}$, and finds a positive contemporaneous relation between the amounts of equity-based compensation awarded and firm performance. However, Mehran (1995) limits the performance measures used to Tobin's $Q^{15}$ and return on assets (ROA). While Mehran (1995) states that shareholder returns, Tobin's $Q$ and ROA are highly correlated, others have argued that Tobin's $Q$ is a better proxy for growth opportunities rather than performance [Mehran (1995)]. As theory suggests that firms with high growth opportunities could use more equity-based compensation [Demsetz and Lehn (1985), Smith and Watts (1992), Gaver and Gaver

\footnotetext{
${ }^{14}$ When the mean value of equity-based compensation was $12.7 \%$ compared to more recent indications that equity based compensation forms around 39\% of United States CEO's remuneration [Towers Perrin (2000)]
} 
(1993)], the use of Tobin's $Q$ is problematic as it could proxy for growth opportunities rather than performance, which could indicate that the direction of the relation runs from Tobin's $Q$ to equity-based compensation.

Frye (2001) follows Mehran (1995), and also limits the performance measures to Tobin's $Q^{16}$ and ROA, and finds mixed results. While she finds that the percentage of equity-based compensation (to total compensation) awarded to employees has a positive relation to firm performance, she finds no relation between performance and the percentage of equity-based compensation awarded to the executives. Frye (2001) also determines the causality of the relation, and shows that causality runs in both directions where performance was proxied as Tobin's $Q$ (which could be due to confounding effects that might result from using Tobin's $Q$ if it also proxies for growth opportunities). When using ROA, Frye concludes that causality runs from performance to the grant of equity to the non-executives. Consequently, Frye (2001) finds little support for a relation between the use of equity-based compensation in executive compensation and subsequent firm performance.

Sesil, Kroumova, Kruse and Blasi (2001) investigate the relation between the use of broad-based stock option plans in compensation and performance in new economy firms. They use a matched pair sample in which a new economy firm using a broad based stock option plan is matched on size and industry with two non-stock option

\footnotetext{
${ }^{15}$ Where the Tobin's $Q$ values are taken from the R\&D Master File, and are defined as the ratio of the market value of the equity to the replacement cost of tangible assets.
} 
firms, and find that overall the use of a broad-based stock option plan is associated with positive performance. However, while they provide evidence of a positive association between broad-based stock option plans and performance, they do not provide evidence of causality. Further, the study is limited to new economy firms.

\subsubsection{Evidence on efficient contracting theory and firm performance}

Core and Guay (1999) investigate equity grants to the CEO from 1992 to 1997 . Using a two stage process, they first estimate the efficient level of CEO equity incentives and find that the levels of incentives provided are positively related to the underlying firm economic characteristics of size, growth opportunities, noise (or risk) and CEO tenure. In the second stage, they show that firms manage grants of new equity in response to deviations from the efficient contract.

Ittner, Lambert and Larcker (2003) investigate whether equity grants are associated with firm performance, but acknowledge that the relation between compensation decisions and firm performance is endogenous. Following Demsetz and Lehn (1985) they suggest that if firms are choosing efficient compensation contracts, then there would be no association between firm performance and the compensation scheme used, once all exogenous determinants of equity choice are controlled for in the model. Ittner, Lambert and Larcker (2003) find no relation between grants to the CEO and subsequent

\footnotetext{
${ }^{16}$ Where Tobin's $Q$ is measured as the market values of stock and debt divided by total assets. Consequently, Frye (2001) does not attempt to determine the replacement cost of assets as required in the Tobin's $Q$ calculations.
} 
stock returns, but that grants to lower organisational levels had a somewhat positive relation with future stock returns in the new economy firms. Ittner, Lambert and Larcker's (2003) paper first identifies the determinants of the ratio of equity grant to salary for different levels of employees, using a sample of firms that all provided equitybased compensation, and the deviations from the average contract are calculated for each firm. Ittner, Lambert and Larcker (2003) then determine the relation between these deviations and firm performance. However, Ittner, Lambert and Larcker (2003) only investigated new economy firms, and only firms that provided equity-based compensation. Further, only market measures of firm performance are used, which could have already adjusted for the deviation in the compensation contract. Consequently, differences in future performance over similar firms that provide very different compensation structures is not investigated.

\subsubsection{Australian evidence}

There are three studies that investigate the relation between pay and firm performance using Australian data, and all of these studies use the limited executive compensation data available prior to 1 July 1998. Defina, Harris and Ramsay (1994) investigate the pay-performance relation in 1990 using 89 of the 136 largest Australian companies. In order to measure CEO compensation, Defina, Harris and Ramsay (1994) assume that the highest paid executive is the CEO of the company, and take the mid-point of the highest banded compensation amount reported as the sum of salary plus bonus for the CEO for the year. Defina, Harris and Ramsay (1994) also include a value for the share options 
and partly-paid shares issued to the CEO during the 1990 year using the Black-Scholes method. They find no relation between changes in CEO compensation and changes in performance for Australian firms in 1990.

Izan, Sidhu and Taylor (1998) use only CEO cash compensation (salary plus bonus) for a sample of 99 firms for the years 1987 to 1992, and consistent with Defina, Harris and Ramsay (1994) use the mid-point of the highest reported compensation band as the CEO's cash compensation for the year. Using both the level of CEO compensation and the change in CEO compensation, Izan, Sidhu and Taylor (1998) also find no evidence of a relation between CEO pay and firm performance.

Matolcsy (2000) investigates the pay-performance relation during different economic cycles using a random sample of 100 firms out of the top 400 listed Australian companies over the period 1987 to 1995 . Matolcsy (2000) also measures CEO cash compensation as the mid-point of the highest compensation band reported, and finds that the pay-performance relation is not stable over time, but rather is a function of specific economic cycles. Matolcsy (2000) demonstrates that there is a zero pay-performance relation during periods of economic downturn and a positive relation during periods of economic upturn. Matolcsy's (2000) results could partially explain the results of Defina, Harris and Ramsay (1994) and Izan, Sidhu and Taylor (1998), as their samples are taken from the period of recession [Defina, Harris and Ramsay (1994)] and soft landing, recession and flat recovery [Izan, Sidhu and Taylor (1998)]. 


\subsubsection{Limitations of the literature to date:}

Murphy (1999) shows that there is very little variation in CEO compensation contracts awarded in the United States. Consequently, all of the investigation into the relation between pay and performance conducted in the United States has concentrated on one type of compensation contract - one in which equity-based compensation has been awarded. Murphy (1999) also indicates that there is little variation in CEO compensation in other countries, in that 9 out of the 23 countries reported offer no equity-based compensation at all ${ }^{17}$. This Chapter provides new evidence on the relation between firm performance and different types of compensation contract used by firms. Further, those empirical studies that test the relation between firm performance and the provision of equity-based compensation [Mehran (1995), Frye (2001)] use limited performance measures in that they both use only Tobin's $Q$ and ROA. This Chapter extends this literature by using both ROA and ROE as accounting measures of performance, and uses market returns ${ }^{18}$ rather than Tobin's $Q$ as a measure of market performance.

This Chapter also improves the empirical design of the two-stage models. Studies have suggested that firm size and complexity or decentralisation could influence the use of equity-based compensation [Ryan and Wiggins (2001), Core, and Guay (2001) Ittner, Lambert and Larcker (2003)] and Chapter Three provides evidence that firms in the

\footnotetext{
${ }^{17}$ These countries are Argentina, Belgium, Germany, Japan, New Zealand, South Korea, Spain, Sweden, and Venezuela is Both unadjusted and adjusted for risk
} 
equity group are significantly more decentralised than those in the cash group. However, this determinant has not been included in the prior studies ${ }^{19}$. Thus the first stage of the model is improved by including variables to proxy for firm decentralisation. The second stage of the model tests deviations from the efficient contract against firm performance, and research to date has used only market based performance measures, and has only tested performance for the following year. This Chapter investigates both accounting and market based measures of performance, as well as looking at firm performance over the following three years ${ }^{20}$ to test the impact of deviations from the efficient contact over a longer period of time.

The Australian evidence on the relation between pay and performance is sparse, with only the relation between changes in pay and changes in performance investigated, and only weak results found. While Matolcsy's (2000) results could provide some explanation for the lack of evidence found by Defina, Harris and Ramsay (1994) and Izan, Sidhu and Taylor (1998), all three of these studies are limited as they test the Australian pay-performance relation using sample years prior to 1 July 1998, where there was only limited executive compensation data available. As discussed in Chapter One, these compensation disclosures were limited to the number of executives receiving cash compensation within bandwidths of $\$ 10,000$, beginning at $\$ 100,000^{21}$, and only summarised information was provided on the conditions of the equity-based

\footnotetext{
${ }^{19}$ Although in their study on stock option plans for non-executive employees, Core and Guay (2001) use the same proxies for firm size and decentralization.

${ }^{20}$ Three following years are chosen as the data up to this point was readily available.

21 These disclosure requirements were introduced in 1986.
} 
compensation awarded to executives. ${ }^{22}$ Consequently, these studies proxy the CEO's salary plus bonus for the year as the mid-point of the highest reported compensation band, which provides a relatively noisy measure of the CEO's compensation due to both possible measurement error in the cash compensation (the mid-point of the band-width taken) and due to the assumption that the highest paid executive is the CEO. The more recent annual reports indicate that in a few companies, the CEO is not the most highly paid executive in the year, most commonly attributable to payouts to other executives on retirement.

In addition, only Defina, Harris and Ramsay (1994) include equity-based compensation. Izan, Sidhu and Taylor (1998) argue that anecdotal evidence suggests that in their sample years of 1987 to 1992, Australian CEO's were more commonly compensated on the basis of salary plus bonus rather than through share schemes and options. None the less, as the evidence cited in this study is only anecdotal, equity-based compensation could have made up a larger than anticipated portion of CEO remuneration. Chapter Two shows that over the sample period 1999 to 2001, equity-based compensation made up between $18 \%$ and $39 \%$ of total compensation (depending on industry) in the equity group firms, and thus the focus on only the cash portion of CEO remuneration could also partially account for the weak results obtained in theses studies. Finally, none of the Australian studies to date have addressed the heterogeneity in compensation contract design across firms, which could also account for the weak results [Hermalin and

\footnotetext{
22 The details provided included the total options issued, the date of the grant, the exercise period and exercise price. In order to obtain the names of the holders of the options, the company's register had to be inspected. This limited disclosure was available under the ASC class onder 94/284.
} 
Wallace (2001)]. This Chapter controls for some of the heterogeneity in the compensation contract designs by comparing the performance of firms that award different types of compensation contract to determine whether there are systematic performance consequences of awarding the different types of compensation contract (cash group versus equity group).

\subsection{THEORY DEVELOPMENT}

Research into management compensation has been interdisciplinary, spanning the areas of economics, finance, psychology and sociology [Bushman and Smith (2001)]. Within the economic and finance literature, most of the research into management compensation has been based upon agency theory and takes an efficient contracting view, where compensation contracting is used to minimise agency costs [Murphy (1999)]. However, alternative views of management compensation have also been suggested in the economics and finance literature, such as the rent extraction perspective, where it is predicted that management will be able to pay themselves relatively more in those firms in which they have relatively more power [Bebchuk, Fried and Walker (2002)]. This Chapter adopts the traditional agency and contracting view of CEO compensation contracting, where an efficient CEO compensation structure is set dependent on the underlying economic characteristics of the firm, and minimises agency costs. 
The theoretical literature has sought to develop models for the efficient compensation structure, and this Chapter looks at two of the views put forward. The first view discussed is that management compensation could include equity-based compensation to maximise firm performance. The prediction from this argument is that the firms offering equity-based compensation would have better performance. The other view discussed is that of compensation structures being set dependent on the underlying firm characteristics. Under this scenario, firm performance would be maximised, regardless of the compensation structure, as long as that compensation structure is set in accordance with firm characteristics. Consequently, there would be no difference in firm performance across the different compensation groups.

\subsubsection{The use of equity-based compensation to improve firm performance:}

A number of researchers have sought to describe the compensation contract structure and types of incentives that the CEO could be offered in order to best align the CEO's incentives with those of the shareholders. For example, Smith and Watts (1982) describe long-term incentive plans as a means to control for agency costs, particularly those associated with a manager's risk aversion. Smith and Watts (1982) argue that where management's wealth is derived solely from human capital and executives are paid by way of fixed salary, management will be more risk averse than is efficient when making investment decisions ${ }^{23}$. They suggest that one way to reduce this conflict over

\footnotetext{
${ }^{23}$ Smith and Watts (1982) argue that when the top executives are paid only by way of fixed salary, they have incentives to reduce the volatility of the firm's cash flow, so that they have ensured a higher probability that the firm's cash flow is sufficient to cover their
} 
risk is to tie management compensation to firm performance, to motivate management to make value-maximising decisions and thus to improve the pay-performance relation [also supported by Holmstrom (1979), Harris and Raviv (1979), Grossman and Hart (1983), Smith and Stultz (1985)].

Hirshleifer and Suh (1992) argue that option based management compensation not only reduces the agency costs associated with management's risk aversion but also reduces the agency costs associated with management's incentives to devote less effort. Consequently, Hirshleifer and Suh (1992) state that shareholders could prefer that management's compensation contain more option-based compensation compared to cash based compensation.

Shleifer and Vishney (1997) argue that when contracts are incomplete, and management possess more information than the shareholders, management usually end up with the residual control rights that provide them with latitude for self-interested behaviour. Shleifer and Vishney (1997) suggest that one solution would be to grant management "a highly contingent, long-term incentive contract ex ante to align his interests with those of investors" [Shleifer and Vishney (1997), p744]. Thus Shleifer and Vishney (1997) imply that firm performance will be positively affected if management is granted equitybased compensation.

fixed claim on the firm. Thus, those executives have incentives to accept projects that reduce the volatility of the firm's cash flow and to reject projects that increase the volatility of the cash flow, regardless of the net present value of those projects. 
Holmstrom (1979), Harris and Raviv (1979), Grossman and Hart (1983), Smith and Watts (1982), Smith and Stultz (1985), Hirshleifer and Suh (1992) and Shleifer and Vishney (1997) all argue that the CEO's motivations are more closely aligned to those of the shareholders if his or her compensation includes some portion of long-term, equity-based compensation. As shareholders are interested in the maximisation of firm performance, these papers suggest that the inclusion of equity-based compensation in the CEO's compensation contract could increase the CEOs incentives to maximise firm performance and consequently firm performance itself.

Consequently, these papers suggest that in an environment where different types of compensation structures exist, the firms that offer equity-based compensation could perform better than those firms that do not.

\subsubsection{Firm characteristics and compensation structure:}

Other studies have argued that equity-based compensation might not always be the best solution for maximising firm performance, but might even impose greater costs on the firm than providing only cash based compensation. For example, Lambert, Larcker and Verrecchia (1991) and Beatty and Zajac (1994) argue that if a risk-averse manager has a significant portion of his wealth tied to the firm's stock price, then his perceived value of the equity portion of the compensation contract can be substantially less than its actual cost to the shareholders. Further, Lambert, Larcker and Verrecchia (1991) argue that the incentive effects of the options are not simple extensions of the comparative 
statistics associated with the Black-Scholes option-pricing model. For example, they show that if there is a sufficiently high probability that the options will finish in the money, those executive stock options can increase management's risk aversion.

Meulbroek (2001) argues that the undiversified managers value stock or options at less than their market price. Meulbroek (2001) shows that an undiversified manager in an internet-based firm values his or her option-based compensation at an average of $53 \%$ of the cost to the firm, and an undiversified NYSE firm manager will value the compensation at around $70 \%$ of the cost to the firm. Meulbroek (2001) also shows that a manager can believe that the firm's stock is undervalued, but still have a strong incentive to sell that stock whenever there is no restriction from doing so. This finding could help to explain some of the presumed irrational sale behaviour of managers documented by Core and Guay (2000). Meulbroek (2001) concludes that while the financial theory has concentrated on the benefits of equity-linked compensation, it has ignored the costs. Further, she argues that as her results show that these costs can be quite large, firms would weigh up the costs and benefits, rather than assuming that the efficient strategy is to have the managers invest all their wealth in the firm.

Consequently, an alternative view to always awarding equity-based compensation is that it might not be efficient for all types of firms to offer equity-based compensation. Rather, compensation structure could be set based on the underlying economic characteristics of the firm, and if it is, firm performance will be maximised [Core, Holthausen and Larcker (1999), Bushman and Smith (2001), Ittner, Lambert and 
Larcker (2003)]. Under this view, if all compensation structures are set efficiently, then firm performance could be maximised in all firms, regardless of the compensation structure employed, and consequently there would be no systematic difference in firm performance across the different compensation groups.

Although firm characteristics could drive compensation structure, efficient contracting will not necessarily be observed within all firms at all times. Core, Guay and Larcker (2003) argue that efficient compensation contracting arrangements evolve over time as firms experiment with new types of incentive contracts and update their beliefs about efficient incentive levels, although they could still be uncertain as to the efficient contract $^{24}$. Milgrom and Roberts (1992) also state that in compensation contracting, people learn over time, and organisations adapt by experimentation and imitation. Consequently, Core, Guay and Larcker (2003) imply that due to the uncertainty and differences in beliefs in efficient contracting arrangements, compensation contracting periodically becomes misaligned within firms, and thus both efficient and inefficient contracting is observed in cross-section. However, unless the uncertainty and differences in beliefs are systematically biased, compensation contracts would be efficient, on average [Core, Guay and Larcker (2003)]. If this is the case, then variation in firm performance will not be associated with compensation structure.

\footnotetext{
${ }^{24}$ In addition, transactions costs reduce the opportunities for firms to continuously re-contract until an efficient solution is found. Core, Guay and Larcker (2003) state that one main difference between the efficient and inefficient contracting views are in the treatment of the transactions costs required to correct sub-efficient contracts. They argue that an implicit assumption of inefficient contracting is that the transactions costs are so great that firms cannot re-contract when inefficiencies arise, while efficient contracting assumes that there are no transactions costs at all, and that firms can continuously re-contract [for example, see Demsetz and Lehn (1985)]
} 
The Australian evidence presented in Chapter Two shows that there are different types of compensation contract awarded, and that the incidence of these different compensation contracts are associated with the underlying firm characteristics predicted by the theoretical literature. Given that the evidence in Chapter Three suggests that firms are choosing structures based on firm characteristics, then is it expected that the different contracts are set (on average) to maximise firm performance, and consequently there will be no link between firm performance and compensation structure.

It is therefore predicted that:

$\mathbf{H}_{1}$ - There is no difference, on average, in firm performance across the different compensation groups.

While $\mathrm{Hl}$ predicts that there are no differences in firm performance on average across the compensation contracting groups, there could be firms in the sample that are not using efficient compensation contracts. Efficient compensation contracting ensures that the compensation structures are set so as to minimise agency costs and maximise firm performance. On the other hand, sub-efficient contracts do not minimise the agency costs and consequently firm performance is adversely affected. It is therefore predicted that: 
$\mathbf{H}_{2}$ Deviation from the efficient compensation structure has a negative impact on firm performance.

\subsection{RESEARCII DESIGN}

\subsubsection{HYPOTHESIS ONE: COMPENSATION STRUCTURE AND FIRM PERFORMANCE}

\subsubsection{Sample and data}

The sample used is the same as that used in Chapters Two and Three and details of the sample selection process can be found in section 2.3 of Chapter Two.

\subsubsection{Experimental design}

Hypothesis One is tested by comparing the performance of firms in the different compensation groups. A number of performance measures are calculated, and are described in Table 4.1 below.

Table 4.1 Performance measures

\begin{tabular}{|ll|l|}
\hline ROA & Return on Assets & $\begin{array}{l}\text { The ratio of EBIT over average total } \\
\text { assets }\end{array}$ \\
\hline ROE & Return on equity & $\begin{array}{l}\text { The ratio of net profit over average total } \\
\text { equity }\end{array}$ \\
\hline$\triangle \mathrm{MVE}$ & $\begin{array}{l}\text { Change in market value } \\
\text { of equity, adjusted for } \\
\text { dividends }\end{array}$ & $\begin{array}{l}\text { Percentage change in the market value of } \\
\text { common stock, adjusted for dividends. }\end{array}$ \\
\hline$\triangle \mathrm{MVErisk}$ & $\begin{array}{l}\text { Change in market value } \\
\text { of equity, adjusted for } \\
\text { dividends and risk }\end{array}$ & $\begin{array}{l}\text { Percentage change in the market value of } \\
\text { common stock, adjusted for dividends } \\
\text { and risk. }\end{array}$ \\
\hline
\end{tabular}


The first three performance measures in Table 4.1 are not adjusted for risk. If there were significant differences in the risks of the firms in the two compensation groups, any differences observed in performance could be due to those risk differences. Firm risk is not discussed in the theoretical papers as one of the determinants of compensation structure and the levels of equity-based compensation. However, given that firms with more growth options are theorised to use more equity-based compensation, firms in the equity group could be perceived as being more risky. However, this should be balanced against the arguments of Lambert, Larcker and Verrecchia (1991), Beatty and Zajac (1994) and Meulbroek (2001), which imply that the riskier the firm, the bigger the gap between the value of the equity-based compensation to the firm and the manager, and thus in risky firms, equity-based compensation could be too expensive to the firm (and therefore inefficient), compared to cash.

In order to control for firm risk, firm betas are sourced from Commsec for the 2004 year, ${ }^{25}$ and risk adjusted market performance is also tested in the model. Using a risk free return of $4.5 \%$ and a market premium of $6 \%$, the market returns for those stocks with available betas were recalculated, and the fourth performance variable $\triangle M V E r i s k$ is included to test the performance comparisons.

\footnotetext{
${ }^{25}$ Only current betas are available from Commsec, so there was data loss due to the firms suspended or delisted between the sample period and 2004, the date of this study
} 


\subsubsection{Other tests - the relation between firm performance and different types of equity-based compensation}

Chapter Two shows that as well as observing homogeneous compensation contracts in the United States, the way in which equity is granted is also homogeneous. In Australia, however, we also observe a number of different ways in which the equity is granted, and it is an empirical question whether these different equity structures lead to different firm performances. In particular, this Chapter is interested in determining whether the inclusion of performance hurdles; whether the options are issued at a premium, discount or fair market value; and whether the different terms of the options lead to a different relation to firm performance. In order to test whether different equity contracts lead to different performance, firm performance is compared across the different option grant characteristics.

\subsubsection{HYPOTHESIS TWO: EFFICIENT COMPENSATION STRUCTURES AND FIRM}

\section{$\underline{\text { PERFORMANCE }}$}

\subsubsection{Sample and data}

Again, the sample is the same as that used throughout the rest of this thesis. However, in order to test hypothesis two, the sample for the 1999 year is used to test the efficient compensation contract group, and performance metrics for the subsequent years to test the performance consequences of choosing a non-efficient compensation contract design. From the original 1999 sample of 227 firms, 17 firms are removed as they have 
missing data in the prior years, and a further 22 firms are removed for the missing noise variable, ${ }^{26}$ leaving a sample of 210 firms included in the analysis.

\subsubsection{Experimental design}

Hypothesis Two is tested by looking at the differences in performance between companies that belong to the predicted efficient contract group and those that are not. The research design is based on two stages:

\subsection{The first stage - the benchmark compensation contract:}

The first stage of the experimental design builds a model to predict whether firms, based on their underlying economic characteristics, could belong to cash or equity compensation groups. This stage relies on the assumption that on average, firms choose the efficient compensation structure as there are no expected systematic biases in the beliefs of firms as to what the efficient structure is [Core, Guay and Larcker (2003)].

The theoretical determinants of the use of equity-based compensation are discussed in Chapter Three, section 3.3. In summary, theoretical studies have argued that equity based compensation could be used to align the interests of shareholders and managers when direct monitoring of employees is difficult, that is, where firms are larger and more decentralised, where there is greater noise in the operating environment and where

\footnotetext{
${ }^{26}$ Noise is defined in Table 4.2, and is the standard deviation in ROA over the prior three years, consistent with Bushman and Smith (2001).
} 
there are greater growth opportunities [Demsetz and Lehn (1985), Smith and Watts (1992), Gaver and Gaver (1993)]. Consequently, the economic characteristics of the firm that are expected to determine compensation structure include the investment opportunity set, firm size and decentralisation, and noise in the operating environment [Ittner, Lambert and Larcker (2003), Ryan and Wiggins (2001), Core and Guay (2001)]. Cash constraints are also expected to be a determinant of compensation structure, as firms could substitute equity-based compensation for cash where they face cash constraints [Ittner, Lambert and Larcker (2003), Core and Guay (2001)]. Chapter Three provides evidence that firms in the different compensation groups have significant differences in some of these underlying economic characteristics, namely size, growth options, decentralisation, and cash constraints.

Also included in the model are accounting and market past performance measures, as Ittner, Lambert and Larcker (2003) argue that equity-based compensation could be used as a reward for past performance. Finally, also included in the model are alternative monitoring mechanisms, as suggested in the prior literature of debt, block shareholders and CEO share ownership [Lambert and Larcker (1987), Ryan and Wiggins (2001), Core and Guay (2001)]. Chapter Three also provides some evidence that CEO share ownership differs significantly between the cash and equity groups.

The economic characteristics of the firm that are expected to determine the structure of compensation contract offered are described in Table 4.2 below. As these firm characteristics are expected to determine the firm's relative demand for a type of 
compensation contract, these factors are predictors of the structure of the offered compensation contract. Consequently, all economic characteristics are measured the year prior to that in which the compensation group membership is measured. Thus compensation group membership is measured in the 1999 year, and economic explanatory variables are taken from 1998.

Table 4.2 - Economic characteristics of the firm that determine CEO compensation structure:

\begin{tabular}{|c|c|c|c|}
\hline Variable & $\begin{array}{c}\text { Variable } \\
\text { name }\end{array}$ & Proxy used & $\begin{array}{l}\text { Predicted } \\
\text { sign } \\
\text { equity }=1 \\
\text { cash }=2\end{array}$ \\
\hline Size & Size $_{t-1}$ & Log of the market value of equity & - \\
\hline $\begin{array}{l}\text { Growth } \\
\text { opportunities }\end{array}$ & $\mathrm{MktBk}_{t-1}$ & Market-to-book ratio & - \\
\hline Decentralisation & Decent $^{\mathrm{sub}}{ }_{t-1}$ & Log of number of subsidiaries & - \\
\hline Decentralisation & \begin{tabular}{|l|} 
Decent \\
${ }_{\text {subfor }}{ }_{t-1}$ \\
\end{tabular} & Log of number of foreign subsidiaries & - \\
\hline Noise & Noise $_{t-x}$ & $\begin{array}{l}\text { Standard deviation of ROA over prior } \\
3 \text { years }\end{array}$ & $+1-$ \\
\hline Cash constraints & Cash $_{t-1}$ & Operating cash flow over total assets & + \\
\hline Past Performance & $\begin{array}{l}\text { Perf }{ }_{t-1}^{\mathrm{R}} \\
\text { Perf }^{\mathrm{ROA}}{ }_{t-1}\end{array}$ & $\begin{array}{l}\text { Prior year share return, dividend } \\
\text { adjusted } \\
\text { Prior year Return on Assets (ROA), } \\
\text { measured as EBIT divided by the } \\
\text { average book value of assets }\end{array}$ & - \\
\hline $\begin{array}{l}\text { \% CEO share } \\
\text { ownership }\end{array}$ & $\begin{array}{l}\text { \%CEOOwn } \\
1\end{array}$ & $\begin{array}{l}\text { Control for the percentage of } \\
\text { common stock owned by the CEO }\end{array}$ & + \\
\hline Leverage & Leverage $_{t-1}$ & $\begin{array}{l}\text { Control for the presence of large debt } \\
\text { holders, proxied by the debt to equity } \\
\text { ratio }\end{array}$ & + \\
\hline $\begin{array}{l}\text { Block } \\
\text { shareholders }\end{array}$ & $\%$ Block $_{t-1}$ & $\begin{array}{l}\text { Control for percentage of stock held } \\
\text { by outside blockholders, measured as } \\
\text { the percentage of total equity owned } \\
\text { by all blockholders with more than } \\
5 \% \text { of the shares outstanding }\end{array}$ & + \\
\hline
\end{tabular}


The following cross-sectional logit model is used to predict membership in either the cash or equity groups:

$$
\begin{aligned}
& \text { Group }_{i t}=\eta_{0}+\eta_{1} \text { Size }_{i t-1}+\eta_{2} \text { MktBk }_{t-1}+\eta_{3} \text { Decent }_{t-1}^{\mathrm{sub}}+\eta_{4} \text { Decent }_{t-1}^{\text {subfor }}+\eta_{5} \\
& \text { Noise }_{t-x}+\eta_{6} \text { Cash }_{t-1}+\eta_{7} \text { Perf }_{t-1}^{\text {SR }}+\eta_{8} \text { Perf }_{t-1}^{\mathrm{ROA}}+\eta_{9} \%_{0} \text { CEOOwn }_{i t-1} \\
& +\eta_{10} \text { Leverage }_{i t-1}+\eta_{11} \% \text { Block }_{i t-1}+\varepsilon_{I}
\end{aligned}
$$

Where:

Group $_{i t}=$ compensation group membership, taking the value of 1 for the equity group, and 2 for the cash.

\subsection{The second stage - deviations from the predicted compensation structure:}

The logit model is used to predict which compensation group a firm could belong to. From this model the performance of the firms that are not in the predicted group is compared to firms that are in the predicted group, with the expectation that the firms that do not use the predicted compensation structure have lower performance. The performance measures are the same as those used to test hypothesis one, and are described in Table 4.1 above, and are reported for both the individual years, and averaged over the three years 1999 to 2001 .

\subsection{RESULTS}

\subsubsection{Iypothesis One}

Hypothesis One tests the differences in performance of firms in the two compensation groups. The performance measures described in Table 4.1 are calculated for each firm 
year, and Table 4.3 reports both the descriptive results for performance of the firms, and the statistical tests of the differences in performance across the two compensation groups. These results are given both for the total sample, and by industry ${ }^{27}$.

${ }^{27}$ Masten (1993) argues that restricting a sample to within an exchange-industry grouping is likely to control for many of the factors that influence firm performance. Consequently, the tests are also run industry by industry. 
Table 4.3 - Descriptive statistics - performance of firms, total sample:

\begin{tabular}{|c|c|c|c|c|c|c|c|c|c|c|c|}
\hline & & \multicolumn{4}{|c|}{ Equity group } & \multicolumn{4}{|c|}{ Cash group } & \multirow{2}{*}{$\begin{array}{c}t \text {-test } \\
(t)\end{array}$} & \multirow{2}{*}{$\begin{array}{c}\text { Mann- } \\
\text { Whitney U }\end{array}$} \\
\hline & & $\mathrm{n}$ & Mean & Median & $\begin{array}{l}\text { Standard } \\
\text { deviation }\end{array}$ & $\mathrm{n}$ & Mean & Median & $\begin{array}{l}\text { Standard } \\
\text { deviation }\end{array}$ & & \\
\hline \multirow{4}{*}{ Total } & ROA & 458 & .059 & .076 & .102 & 238 & .079 & .076 & .077 & $-2.677^{* * *}$ & $50305^{*}$ \\
\hline & ROE & 458 & .082 & .101 & .163 & 238 & .099 & .098 & .133 & -1.460 & 52977 \\
\hline & $\triangle \mathrm{MVE}$ & 457 & .170 & .091 & .577 & 238 & .155 & .046 & .504 & .340 & 52827 \\
\hline & $\triangle$ MVErisk & 306 & .080 & .001 & .599 & 179 & .072 & -.049 & .514 & .164 & 26600 \\
\hline
\end{tabular}

\begin{tabular}{|c|c|c|c|c|c|c|c|c|c|c|c|}
\hline & & \multicolumn{4}{|c|}{ Equity group } & \multicolumn{4}{|c|}{ Cash group } & \multirow{2}{*}{$\begin{array}{c}t \text {-test } \\
(t)\end{array}$} & \multirow{2}{*}{$\begin{array}{c}\text { Mann- } \\
\text { Whitney U }\end{array}$} \\
\hline & & $n$ & Mean & Median & $\begin{array}{l}\text { Standard } \\
\text { deviation }\end{array}$ & $n$ & Mean & Median & $\begin{array}{l}\text { Standard } \\
\text { deviation }\end{array}$ & & \\
\hline \multirow{4}{*}{ Mining } & ROA & 89 & .017 & .033 & .100 & 42 & .055 & .066 & .109 & $-1.975^{* *}$ & $1507^{*}$ \\
\hline & ROE & 89 & .012 & .027 & .176 & 42 & .064 & .067 & .168 & -1.603 & 1554 \\
\hline & $\triangle \mathrm{MVE}$ & 88 & .086 & .062 & .560 & 42 & .178 & .043 & .568 & -.868 & 1746 \\
\hline & $\triangle \mathrm{MVErisk}$ & 36 & .016 & .019 & .621 & 27 & .125 & -.033 & .549 & -.720 & 453 \\
\hline
\end{tabular}

\begin{tabular}{|c|c|c|c|c|c|c|c|c|c|c|c|}
\hline & & \multicolumn{4}{|c|}{ Equity group } & \multicolumn{4}{|c|}{ Cash group } & \multirow{2}{*}{$\begin{array}{l}t \text {-test } \\
(\mathrm{t})\end{array}$} & \multirow{2}{*}{$\begin{array}{c}\text { Mann- } \\
\text { Whitney U }\end{array}$} \\
\hline & & $\mathrm{n}$ & Mean & Median & $\begin{array}{l}\text { Standard } \\
\text { deviation }\end{array}$ & $\mathrm{n}$ & Mean & Median & $\begin{array}{l}\text { Standard } \\
\text { deviation }\end{array}$ & & \\
\hline \multirow{4}{*}{ Manufacturing } & ROA & 196 & .070 & .085 & .098 & 83 & .080 & .074 & .069 & -.873 & 8111 \\
\hline & ROE & 196 & .095 & .106 & .155 & 83 & .094 & .081 & .125 & .036 & 7691 \\
\hline & $\triangle \mathrm{MVE}$ & 196 & .154 & .031 & .586 & 83 & .190 & .062 & .494 & -.495 & 7776 \\
\hline & $\triangle M V E r i s k$ & 135 & .048 & -.075 & .619 & 66 & .094 & -.021 & .513 & -.521 & 4206 \\
\hline
\end{tabular}




\begin{tabular}{|c|c|c|c|c|c|c|c|c|c|c|c|}
\hline & & \multicolumn{4}{|c|}{ Equity group } & \multicolumn{4}{|c|}{ Cash group } & \multirow{2}{*}{$\begin{array}{c}\text { t-test } \\
(t)\end{array}$} & \multirow{2}{*}{$\begin{array}{c}\text { Mann- } \\
\text { Whitney U }\end{array}$} \\
\hline & & $n$ & Mean & Median & $\begin{array}{l}\text { Standard } \\
\text { deviation }\end{array}$ & $\mathrm{n}$ & Mean & Median & $\begin{array}{l}\text { Standard } \\
\text { deviation }\end{array}$ & & \\
\hline \multirow{4}{*}{$\begin{array}{l}\text { Banking \& } \\
\text { finance }\end{array}$} & ROA & 48 & .027 & .010 & .076 & 29 & .054 & .040 & .051 & $-1.730^{*}$ & $500^{* *}$ \\
\hline & ROE & 48 & .103 & .122 & .134 & 29 & .091 & .087 & .063 & .456 & 622 \\
\hline & $\triangle \mathrm{MVE}$ & 48 & .244 & .150 & .484 & 29 & .211 & .108 & .532 & .286 & 644 \\
\hline & $\triangle \mathrm{MVErisk}$ & 37 & .143 & .043 & .490 & 26 & .143 & -.012 & .518 & -.003 & 456 \\
\hline
\end{tabular}

\begin{tabular}{|c|c|c|c|c|c|c|c|c|c|c|c|}
\hline & & \multicolumn{4}{|c|}{ Equity group } & \multicolumn{4}{|c|}{ Cash group } & \multirow{2}{*}{$\begin{array}{c}t \text {-test } \\
(\mathrm{t})\end{array}$} & \multirow{2}{*}{$\begin{array}{c}\text { Mann- } \\
\text { Whitney U }\end{array}$} \\
\hline & & $\mathrm{n}$ & Mean & Median & $\begin{array}{l}\text { Standard } \\
\text { deviation }\end{array}$ & $\mathrm{n}$ & Mean & Median & $\begin{array}{l}\text { Standard } \\
\text { deviation }\end{array}$ & & \\
\hline \multirow{4}{*}{ Other } & ROA & 125 & .083 & .094 & .106 & 84 & .098 & .084 & .069 & -1.111 & 5111 \\
\hline & ROE & 125 & .102 & .125 & .162 & 84 & .125 & .120 & .135 & -1.085 & 5058 \\
\hline & $\triangle \mathrm{MVE}$ & 125 & .226 & .126 & .605 & 84 & .089 & .003 & .473 & $1.737^{*}$ & $4419^{*}$ \\
\hline & SMVErisk & 98 & .125 & .022 & .604 & 60 & -.008 & -.109 & .499 & 1.430 & $2449^{*}$ \\
\hline
\end{tabular}

*** significant at the 0.01 level (2-tailed) ** significant at the 0.05 level (2-tailed) * significant at the 0.10 level (2-tailed

where:

ROA $=$ retum on total average assets

$R O E=$ retum on total average equity

$\triangle M V E=$ percentage change in total market value of common equity, adjusted for dividends

$\triangle M V E r i s k$ = percentage change in total market value of common equity, adjusted for dividends and risk 
The total sample results show little variation in firm performance between the two compensation groups, in that the only significant differences in firm performance is on performance measured as ROA. The cash group has significantly higher ROA compared to the equity group. From Table 2.B.2 in Appendix 2.B, current ROA also has a significant positive relation to total levels of compensation in the cash group, but not in the equity group. The combination of results from Table 4.3 above and Table 2.B.2 in Appendix 2.B suggests that ROA is significantly higher in the cash firms, and the CEOs are awarded accordingly. However, the better ROA does not appear to translate into better market performance.

The industry results also reveal few differences in performance across the two compensation groups. The differences in the ROA measure are most significant in the mining industry, but again, this improved ROA in the cash group does not translate into better market performance. Interestingly however, Tables 2.B.2 and 2.B.a in Appendix 2.B show that current ROA has no impact on the levels of total compensation in the mining industry.

The manufacturing industry has the largest sample size, and these results reveal that there are no significant differences in any of the performance measures.

The banking and finance industry also shows that the cash firms have significantly better ROA compared to the equity firms, although this result is weaker than that 
observed in the mining industry. As with the mining industry, this ROA result does not translate into better market performance in the cash firms compared to the equity firms.

The only industry to show any significance in the differences in market performance is the other industry, where the equity group's performance is better than that of the cash group. However, this result has only very weak significance, and that significance is reduced further when the market returns are adjusted for risk. Given that these results are only significant at the $10 \%$ level, they should be interpreted with care.

In order to ensure that the market results are not confounded by other firm characteristics that affect performance, sensitivity testing is conducted on the two market measures of performance. Ordinary least squares (OLS) regressions are estimated that include controls for firm size and growth options, as small firms and firms with high market-to-book ratios tend to earn higher returns [Fama and French (1992)]. The results are reported in Table 4.4. 


\section{TABLE 4.4 - SUMMARY OF THE OLS REGRESSION COEFFICIENTS FOR THE RELATION BETWEEN FIRM PERFORMANCE, GROUP MEMBERSHIP AND PERFORMANCE \\ ConTrols:}

The coefficients are based on the following equation: $\operatorname{Perf}_{i t}=\eta_{0}+\eta_{l}$ Group memb $_{i t}+\eta_{2}$ Size $_{i t-1}+\eta_{3} \mathrm{MktBk}_{i t-1}+\varepsilon_{1 .}$. The $t$ statistics are reported in brackets.

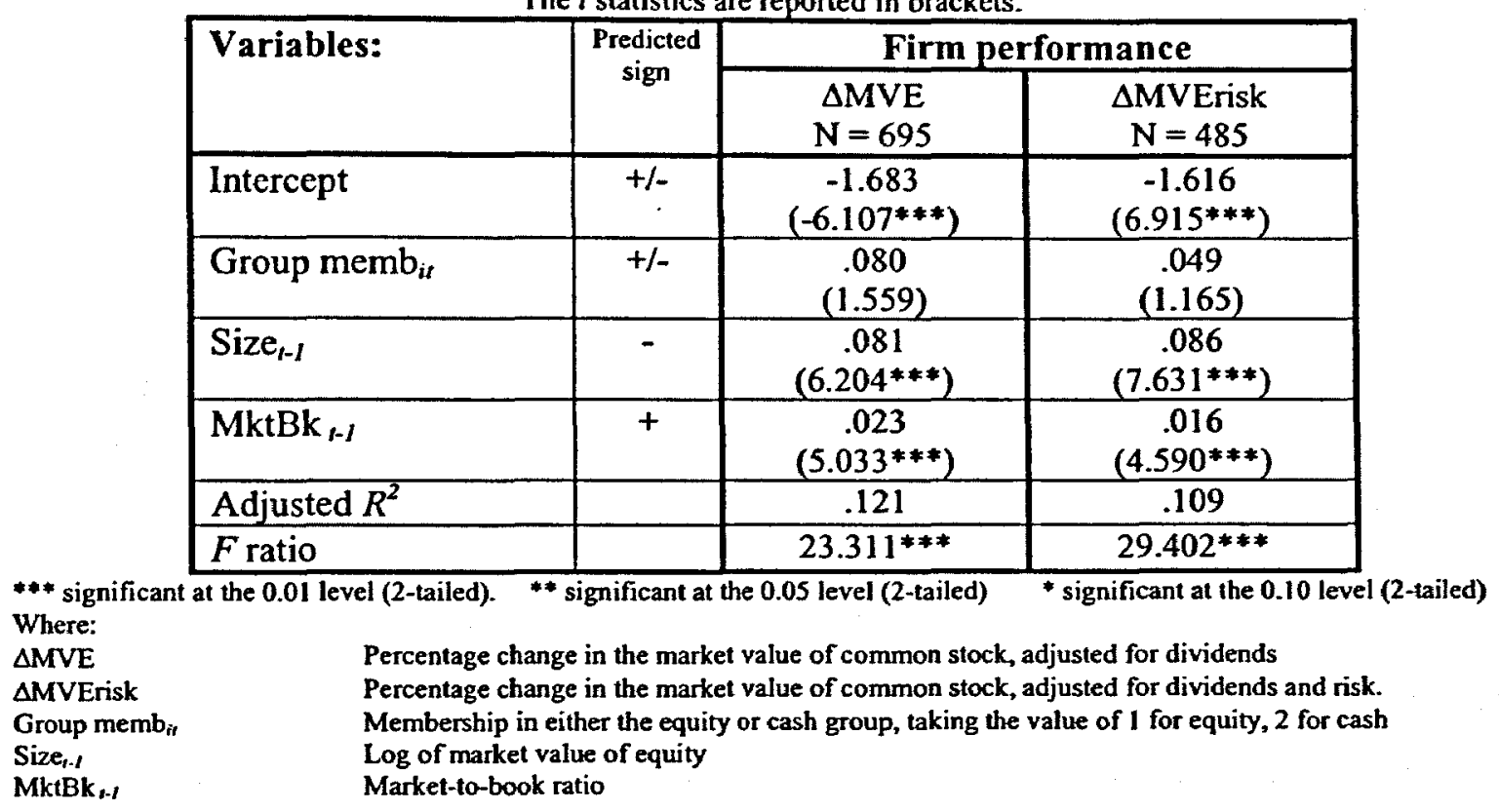

Table 4.4 reveals that group membership is not significant in determining firm performance, consistent with the results in Table 4.3. Both firm size and growth options are significant, however the firm size variable is contra to expectations, in that firm size is positively associated with firm performance ${ }^{28}$.

One final sensitivity test is run on the sample. As Australian accounting standards do not require the expensing of equity-based compensation, if firms were substituting equity-based compensation for cash the accounting performance of those firms could be artificially improved. Alternatively, firms not using equity could have to pay relatively higher amounts of cash, and thus their accounting performance would be lower 
compared to firms paying equity. However, the results in Chapter Two show that the equity firms pay more cash compensation than the cash group do, on average. In order to test whether this has had an impact on the accounting measures of performance, total cash compensation is added back to EBIT and ROA is recalculated ${ }^{29}$. The results are reported in Table 4.5:

Table 4.5 - Descriptive statistics - performance of firms on the adjusted ROA measure, total sample:

\begin{tabular}{|c|c|c|c|c|c|c|c|c|c|c|c|}
\hline & & \multicolumn{4}{|c|}{ Equity group } & \multicolumn{4}{|c|}{ Cash group } & \multirow{2}{*}{$\begin{array}{c}\text { t-test } \\
(t)\end{array}$} & \multirow{2}{*}{$\begin{array}{c}\text { Mann- } \\
\text { Whitney } \\
\text { U }\end{array}$} \\
\hline & & $\overline{\mathbf{n}}$ & Mean & Med & $\begin{array}{l}\text { Std } \\
\text { dev }\end{array}$ & n & Mean & Med & $\begin{array}{l}\text { Std } \\
\text { dev }\end{array}$ & & \\
\hline Total & ROAadj & 458 & .0617 & .078 & .103 & 238 & .083 & .079 & .079 & $-2.753^{* * *}$ & $50001^{*}$ \\
\hline
\end{tabular}

Table 4.5 shows that with the salary adjustment, the ROAs of each group are higher.

The results in Table 4.3 show that ROA is significantly higher in the cash group compared to the equity group, and this result is maintained once cash salaries have been adjusted for. However, the significance of the difference has increased, which indicates that the equity group do appear to be substituting equity for cash compensation, and / or the cash group are paying relatively more cash to compensate for not paying equitybased compensation.

\footnotetext{
${ }^{28}$ While this result is contra to expectations, it may be a function of the economic climate of this period. However, there are no other Australian studies to benchmark this result too.

${ }^{29}$ Alternatively, the value of the stock options granted could be added back to market value and the market value differences examined. However, as the stock option value is only an estimate (using Black-Scholes), any adjustment to market returns could be biased. Consequently, cash compensation is used in preference as it is an exact number.
} 
Overall, these results provide little evidence that on average, performance is significantly different between the cash and equity groups. The only significant differences in performance are observed in the ROA measure, but this does not translate into improved market performance. Differences observed in market returns are only very weakly significant, and there are no observable differences in the ROE measure.

These results indicate that there is little variation in performance across the cash and equity compensation groups, which implies that there are no systematic performance improvements to be obtained by all firms offering (or not offering) equity-based compensation to their CEOs. Rather, these results indicate that firms could be choosing compensation contract structures efficiently, on average. However, although variation in the compensation contract is observed in the Australian market, the same level of variation does not seem evident in the US. These results could indicate that it could be efficient for some firms in the US not to use any equity-based compensation. However, there are differences between the two economies, in particular in relation to the taxing of options, as firms in the US receive a tax deduction for certain types of option grants, while the same is not true in Australia. This tax deduction could make the use of options relatively less expensive in the US compared to Australia, and also indicates that there are other reasons why options could be used in the US. 


\subsubsection{Other tests - the structure of equity awards and firm performance:}

The performance consequences of different types of option grant are also investigated and the detailed results are reported in Appendix 4.A. The univariate and multivariate tests indicate that option terms and option exercise prices are not related with firm performance, but the existence of hurdles is positively related to accounting performance.

\subsubsection{Hypothesis Two: Efficient compensation structures and firm performance}

\subsubsection{First stage - predicted group membership}

First, Table 4.6 provides the descriptive results for the economic characteristics (measured in 1998) of the firm that are predicted to drive compensation structure for 1999. The descriptive results are provided for the total sample, and are also split between the two compensation groups. 
Table 4.6 - Descriptive Results for the ex ante economic characteristics of firms in the 1999 year:

\begin{tabular}{|c|c|c|c|c|c|c|c|c|c|}
\hline & \multicolumn{3}{|c|}{$\begin{array}{c}\text { Total } \\
\mathrm{n}=210 \text { for all variable but } \\
\text { noise where } \mathrm{n}=188\end{array}$} & \multicolumn{3}{|c|}{$\begin{array}{c}\text { Equity } \\
n=137 \text { for all variable but } \\
\text { noise where } n=121\end{array}$} & \multicolumn{3}{|c|}{$\begin{array}{c}\text { Cash } \\
n=73 \text { for all variable but } \\
\text { noise where } n=67\end{array}$} \\
\hline & Mean & Median & $\begin{array}{l}\text { Std } \\
\text { dev }\end{array}$ & Mean & Median & $\begin{array}{l}\text { Std } \\
\text { dev }\end{array}$ & Mean & Median & $\begin{array}{l}\text { Std } \\
\text { dev }\end{array}$ \\
\hline Size $_{t-1}$ & 19.216 & 18.950 & 1.673 & 19.379 & 19.063 & 1.800 & 18.911 & 18.739 & 1.363 \\
\hline MktBk $_{t-1}$ & 2.610 & 1.560 & 5.117 & 2.918 & 1.544 & 6.203 & 2.032 & 1.582 & 1.670 \\
\hline Decent $^{\text {sub }}{ }_{t-1}$ & 2.208 & 2.674 & 2.953 & 2.466 & 2.773 & 2.796 & 1.726 & 2.565 & 3.193 \\
\hline Decent $^{\text {subfor }}{ }_{r-1}$ & -1.791 & 1.099 & 5.370 & -.860 & 1.387 & 5.141 & -3.540 & 0 & 5.389 \\
\hline Noise $_{t-x}$ & .051 & .017 & .089 & .053 & .017 & .095 & .047 & .019 & .078 \\
\hline Cash $_{1-1}$ & .068 & .080 & .136 & .052 & .065 & .143 & .098 & .089 & .117 \\
\hline $\operatorname{Perf}_{t-1}^{S R}$ & -.082 & -.137 & .437 & -.076 & -.107 & .424 & -.094 & -.171 & .463 \\
\hline $\operatorname{Perf}_{1-I}^{R O A}$ & .047 & .073 & .183 & .020 & .060 & .213 & .098 & .090 & .088 \\
\hline$\%$ CEOown $n_{r-1}$ & .057 & .001 & .129 & .033 & .001 & .087 & .101 & .001 & .176 \\
\hline Leverage $_{t-1}$ & 2.283 & 1.085 & 6.068 & 2.725 & 1.093 & 7.294 & 1.454 & 1.053 & 2.310 \\
\hline$\%$ Block $_{t-1}$ & .434 & .440 & .225 & .391 & .389 & .213 & .514 & .510 & .226 \\
\hline
\end{tabular}

\begin{tabular}{|c|c|}
\hline Where: & \\
\hline Size $_{r-1}$ & Log of the market value of equity \\
\hline MktBk & Market-to-book ratio \\
\hline Decent $^{\sin }$,t & Log of number of subsidiaries \\
\hline Decent $^{\text {subior }}$-1 & Log of number of foreign subsidiaries \\
\hline Noise $_{t-\pi}$ & Standard deviation of ROA over prior 3 years \\
\hline Cash ,.- & Operating cash flow over total assets \\
\hline Perf ${ }^{S R}, 1$ & Prior year share return, dividend adjusted \\
\hline $\begin{array}{l}\text { Perf } \\
\% \text { CEOA } \\
\text { "-l }\end{array}$ & $\begin{array}{l}\text { Prior year Return on Assets (ROA), measured as EBIT divided by the average book value of assets } \\
\text { Percentage of common stock owned by the CEO }\end{array}$ \\
\hline Leverage $_{t-1}$ & Debt to equity ratio \\
\hline$\%$ Block $_{r-1}$ & Percentage of total equity owned by all blockholders with more than $5 \%$ of the shares outstanding \\
\hline
\end{tabular}

Table 4.6 shows that the characteristics of the firms for the 1999 year are similar to those for the firms across all three years and reported in Table 3.3 of Chapter Three the equity group firms are larger, have more growth options and are more complex, but have lower available cash and lower CEO share ownership. Leverage is higher in the equity firms, but the percentage of shares owned by outside blockholders is greater in the cash group. Finally, the equity firm's prior share returns are better but prior ROA is worse, compared to the cash firms. 
Table 4.7 below reports the logistic regression results for the economic determinants of compensation group membership: 


\section{TABLE 4.7 - SUMMARY OF THE LOGIT REGRESSION COEFFICIENTS FOR THE RELATION BETWEEN COMPENSATION GROUP MEMBERSIIIP AND UNDERLYING FIRM CHARACTERISTICS:}

The coefficients are based on the following equation: Group $p_{i t}=\eta_{0}+\eta_{1}$ Size $_{i-1}+\eta_{2} \mathbf{M k t B k}_{t-1}+\eta_{3}$ Decent $^{\text {sub }}{ }_{t-1}+\eta_{4}$ Decent $^{\text {subfor }}{ }_{t-1}+\eta_{3}$ Noise $_{t-x}+\eta_{6}$ Cash $_{t-1}+\eta_{7}$ Perf $^{\mathrm{sR}}{ }_{t-1}+\eta_{8}$ Perf $^{\text {ROA }}{ }_{t-1}+\eta_{9} \%$ CEOOWn $_{i-t}$ $+\eta_{10}$ Leverage $_{i t-1}+\eta_{11} \%$ Block $_{i t-1}+\varepsilon_{1} \eta_{7} \%$ Block $_{i t-1}+\eta_{8}$ Leverage $_{i t-1}+\eta_{9} \%$ ManageOwn $_{i-1}+\varepsilon_{t .} \mathrm{n}=188^{30}$

\begin{tabular}{|c|c|c|c|c|}
\hline Variables: & $\begin{array}{l}\text { Predicted } \\
\operatorname{sign}^{31}\end{array}$ & Coefficient & $\begin{array}{c}\text { Standard } \\
\text { Error }\end{array}$ & Wald Statistic \\
\hline Constant & $+/-$ & -2.222 & 2.460 & .816 \\
\hline Size $_{t-1}$ & - & .008 & .129 & .004 \\
\hline $\mathrm{MktBk}_{\mathrm{f}-\mathrm{l}}$ & - & -.121 & .111 & 1.183 \\
\hline Decent $^{\text {sub }}{ }_{1-l}$ & - & -.040 & .090 & .200 \\
\hline Decent $^{\text {subfor }}{ }_{t-1}$ & - & -.082 & .039 & $4.386^{* *}$ \\
\hline Noise $_{t-x}$ & - & .009 & 2.033 & .000 \\
\hline Cash $_{t-1}$ & + & 2.190 & 1.735 & 1.594 \\
\hline $\operatorname{Perf}^{\mathrm{SR}}{ }_{r-1}$ & - & -.334 & .450 & .549 \\
\hline $\operatorname{Perf}_{1-I}^{\mathrm{ROA}}$ & - & 5.256 & 2.218 & $5.618^{* *}$ \\
\hline$\%$ CEOOWn $n_{t-l}$ & + & 3.267 & 1.501 & $4.738^{* *}$ \\
\hline Leverage $_{t-1}$ & + & -.050 & .057 & .787 \\
\hline$\%$ Block $_{\text {f-1 }}$ & + & 2.153 & .859 & $6.286^{* *}$ \\
\hline \multicolumn{5}{|c|}{$\%$ correct $=70.2 \%$} \\
\hline \multicolumn{5}{|c|}{ Chi-square $=44.117^{* * *}$ Nagelkerke $R^{2}=.287$} \\
\hline 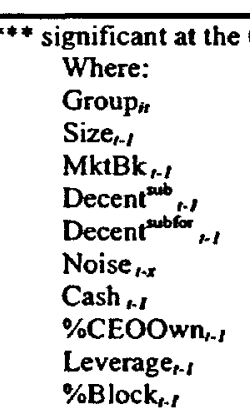 & $\begin{array}{l}\text { vel (2-tailed) ** sign } \\
\text { Compensation group } \\
\text { Log of the market val } \\
\text { Market-to-book ratio } \\
\text { Log of number of sub } \\
\text { Log of number of fon } \\
\text { Standard deviation of } \\
\text { Operating cash flow } \\
\text { Percentage of commo } \\
\text { Debt to equity ratio } \\
\text { Percentage of total eq }\end{array}$ & $\begin{array}{l}\text { ant at the } 0.05 \text { level ( } 2 \\
\text { mbership, taking the va } \\
\text { of equity } \\
\text { iaries } \\
\text { subsidiaries } \\
\text { A over prior } 3 \text { years } \\
\text { total assets } \\
\text { lock owned by the CEC } \\
\text { owned by all blockho }\end{array}$ & $\begin{array}{l}\text { ed) }{ }^{*} \text { significa } \\
\text { of } 1 \text { for the equity }\end{array}$ & $\begin{array}{l}\text { he } 0.10 \text { level (2-tailed) } \\
\text { and } 2 \text { for the cash group }\end{array}$ \\
\hline
\end{tabular}

\footnotetext{
${ }^{30}$ Sample reduced for the missing risk variable

${ }^{31}$ The equity group takes the value of 1 , and cash 2
} 
The Chi-square statistic indicates that the model is significant in explaining group membership, and when comparing the predicted group membership to the observed group membership, the regression correctly predicts in around $70.2 \%$ of cases.

The logit analysis reveals that firm decentralisation is an economic determinant of group membership - as firms are more decentralised, they are more likely to use equity-based compensation, consistent with theory. Also significant is the percentage of shares owned by the CEO - where the CEO owns more shares, firms are less likely to use equity-based compensation. The presence of outside blockholders is also significant, and the direction indicates that where outside blockholders own more shares, firms are more likely to belong to the cash group, which is consistent with the argument that outside blockholders could provide monitoring, and act as a substitute for equity compensation. Finally past ROA is also significant in determining group membership, in that the cash group firms have higher past ROA. However, this result is contra to that suggested in the prior literature. Ittner, Lambert and Larcker (2003) argue that equitybased compensation is used as a reward for past performance - this model shows that firms with strong past ROA performance are more likely to remain in the cash group. This could suggest that in firms with good ROA performance, CEOs are more likely to want their compensation tied to accounting measures, and therefore not want equitybased compensation. Alternatively, firms could be trying to maximise accounting performance, and therefore choose to grant only cash.

Table 4.8 compares these results to those obtained in the United States' studies: 
TABle 4.8 - COMPARISON BETWEen the RESUltS in this Chapter to UNITEd STATES' RESUltS

\begin{tabular}{|c|c|c|c|c|}
\hline \multirow[t]{2}{*}{ Variable } & \multirow{2}{*}{$\begin{array}{c}\text { RESULTS } \\
\text { CHAPTER FOUR } \\
\text { TABLE } 4.10 \\
\text { (SIGN REVERSED TO } \\
\text { MATCH U.S. STUDIES) }\end{array}$} & \multicolumn{3}{|c|}{$\begin{array}{l}\text { UNITED STATES' RESULTS } \\
\text { ALL BASED ON THE PERCENTAGE OF EQUITY AWARDED TO THE CEO }\end{array}$} \\
\hline & & $\begin{array}{l}\text { Core and GuAY (1999) } \\
\text { TABLE 4, P } 170\end{array}$ & $\begin{array}{c}\text { RYAN AND WIGGINS } \\
(2001) \\
\text { TABLE 4, P } 115 \\
\end{array}$ & $\begin{array}{l}\text { ITTNER, LAMBERT AND } \\
\text { LARCKER (2003) } \\
\text { TABLE 5 P 107 } \\
\end{array}$ \\
\hline Size $_{t-1}$ & No result & Positive, significant & Positive, significant & Not tested \\
\hline $\mathrm{MktBk}_{t-1}$ & No result & Positive, significant & Positive, significant & Positive, significant \\
\hline Decent $^{\text {sub }}{ }_{t-1}$ & No result & Not tested & Not tested & Not tested \\
\hline Decent $^{\text {subfor }}{ }_{t-1}$ & Positive, significant & Not tested & Not tested & Not tested \\
\hline Noise $_{t-x}$ & No result & Not tested & Not tested & No result \\
\hline Cash $_{t-1}$ & No result & Positive, significant & Positive, significant & Positive, significant \\
\hline $\operatorname{Perf}^{\mathrm{SR}}{ }_{t=1}$ & No result & No result & Not tested & No result \\
\hline $\operatorname{Perf}_{t-1}{ }^{20 A}$ & Negative, significant & Not tested & Not tested & No result \\
\hline$\% \mathrm{CEOOWn}_{t-l}$ & Negative, significant & Not tested & Negative, significant & Not tested \\
\hline Leverage $_{t-1}$ & No result & Not tested & $\begin{array}{l}\text { Negative, weak } \\
\text { significance }\end{array}$ & Negative, significant \\
\hline$\% \mathrm{Block}_{t-1}$ & Negative, significant & Not tested & $\begin{array}{l}\text { Negative, weak } \\
\text { significance }\end{array}$ & No result \\
\hline
\end{tabular}


Table 4.8 shows that the only consistently used economic determinants of equity-based compensation in the United States' literature are growth options and cash constraints, and each study finds that growth options are positively associated with the use of equitybased compensation and that the more cash constrained the firm, the more the equitybased compensation. In contrast, this Chapter finds no significant result on either of those economic characteristics, although Chapter Three does find that the equity firms have significantly more growth options compared to the cash firms.

This Chapter finds that the significant economic characteristics are firm decentralisation (positive relation to use of equity-based compensation), prior accounting performance, CEO share ownership and the presence of outside blockholders (all with a negative relation to use of equity-based compensation). None of the studies to date use a proxy for firm decentralisation, even though the theoretical literature predicts that equity will be used in firms in which it is harder to monitor management. The results of this Chapter show that this proxy is significant in the CEO compensation contract choice. Prior accounting performance is included in one prior study, but no result is found, while the results in this Chapter on CEO share ownership and the presence of outside blockholders is consistent with the results found in those prior studies including those variables.

However it is important to note that the studies in the United States are investigating the percentage of equity awarded rather than the decision of whether or not to use equitybased compensation at all. 
Table 4.9 below shows the classifications of the predicted and observed compensation group memberships:

Table 4.9 - Classification Table: ${ }^{32}$

\begin{tabular}{|c|l|c|c|c|}
\hline \multicolumn{2}{|c|}{} & \multicolumn{2}{|c|}{ Predicted } & $\%$ correct \\
\cline { 3 - 5 } & Equity & Cash & \\
\hline \multirow{3}{*}{ Observed } & Equity $(\mathrm{n}=121)$ & 115 & 6 & $95 \%$ \\
\cline { 2 - 5 } & Cash (n=67) & 50 & 17 & $25 \%$ \\
\hline
\end{tabular}

The distributions of the incorrect firms are interesting in that the equity firms are predominantly in the correct group- only 6 of the equity firms could be in the cash group. The balance of the incorrect firms are cash firms that could have equity-based compensation plans in place for their CEOs. This result could be driven by the costs involved in implementing an equity-based compensation scheme - the schemes must be presented and approved by the Annual General Meeting of Shareholders. Also, due to the lack of a tax deduction to the companies for options (while cash salary and bonuses etc are tax deductible), options are relatively more expensive for firms to use. Thus firms could be reluctant to institute equity-based compensation schemes, and those firms that do use them have clear reasons to do so. Alternatively, the tax profile of a firm could be a potential explanatory variable for compensation choice, and a potential for further research - firms with tax losses or low effective tax rates ${ }^{33}$ might not see options as expensive as firms with higher effective tax rates.

\footnotetext{
${ }^{32}$ Given that around two thirds of the sample are in the equity group, the cut value was set at $67 \%$

${ }^{33}$ During this sample period all Australian companies were subject to one tax rate, rather than a marginal rate scale. However, special tax deductible items such as research and development and the availability of tax losses can lead to different effective tax rates across firms, especially in the short-run.
} 
Given that firms are classified into the equity group on the basis of an option plan being in place rather than the actual using of the plan, one possible action for the "incorrect" equity firms to correct the CEO's compensation contract would be to not make any option grants to the CEO. The option grants of the 6 "incorrect" equity firms is investigated, and all 6 firms made option grants during the sample period, which indicates that these firms have not made any changes to their CEO's compensation contract - they are still actively using equity-based compensation.

\subsubsection{Second stage - predicted group membership and firm performance} If the firms identified in the logit model as being "incorrect" are using the wrong compensation contract, the agency costs in those firms are not minimised, and consequently firm performance would suffer compared to the "correct" firms, who are minimising agency costs. The performance for each individual year 1999, 2000 and 2001 , along with the 3 year average performance of those firms that are in the correctly predicted compensation group (correct) is compared to those firms that are not in their predicted compensation groups (incorrect), and the results are given in Table 4.10 below: 
Table 4.10 - Performance results of firms in the predicted group vs. those that are not:

\begin{tabular}{|c|c|c|c|c|c|c|c|c|c|c|}
\hline & \multicolumn{4}{|c|}{ Correct } & \multicolumn{4}{|c|}{ Incorrect } & \multicolumn{2}{|c|}{ Correct vs. Incorrect } \\
\hline & $\mathrm{n}$ & Mean & Median & Std dev & $\mathrm{n}$ & Mean & Median & Std dev & $\begin{array}{l}t \text {-test } \\
(t)\end{array}$ & $\begin{array}{c}\text { Mann-Whitney } \\
\text { U } \\
\end{array}$ \\
\hline ROE 1999 & 133 & .071 & .103 & .205 & 55 & .098 & .103 & .101 & -.903 & 3620 \\
\hline ROE 2000 & 131 & .078 & .113 & .204 & 54 & .095 & .105 & .117 & -.560 & 3462 \\
\hline ROE 2001 & 125 & .080 & .090 & .179 & 53 & .082 & .060 & .126 & -.099 & 3149 \\
\hline Ave ROE & 133 & .066 & .102 & .186 & 55 & .089 & .075 & .089 & -.851 & 3492 \\
\hline ROA 1999 & 133 & .078 & .085 & .082 & 55 & .087 & .076 & .057 & -.756 & 3516 \\
\hline ROA 2000 & 132 & .071 & .084 & .111 & 55 & .092 & .081 & .070 & -1.288 & 3606 \\
\hline ROA 2001 & 129 & .049 & .069 & .121 & 55 & .067 & .062 & .071 & .1 .009 & 3474 \\
\hline Ave ROA & 132 & .075 & .084 & .077 & 55 & .078 & .069 & .068 & -.224 & 3484 \\
\hline$\triangle \mathrm{MVE} 1999$ & 133 & .441 & .220 & .956 & 55 & .239 & .180 & .397 & 1.510 & 3556 \\
\hline$\triangle M V E 2000$ & 128 & .196 & .080 & .498 & 53 & .032 & -.040 & .285 & $2.247^{* *}$ & $2835^{*}$ \\
\hline$\triangle \mathrm{MVE} 2001$ & 124 & .121 & .020 & .642 & 53 & .065 & .000 & .389 & .590 & 3282 \\
\hline Ave $\triangle \mathrm{MVE}$ & 133 & .363 & .140 & .780 & 55 & .179 & .060 & .380 & $1.662^{*}$ & 3178 \\
\hline$\Delta$ MVErisk 1999 & 90 & .394 & .140 & .944 & 36 & .096 & .135 & .328 & $1.845^{*}$ & 1523 \\
\hline$\triangle \mathrm{MVErisk} 2000$ & 90 & .209 & .060 & .544 & 36 & -.005 &. .030 & .278 & $2.248^{* *}$ & 1344 \\
\hline$\Delta \mathrm{MVErisk} 2001$ & 90 & .010 & .085 & .646 & 36 &. .071 & -.080 & .277 & .724 & 1583 \\
\hline Ave $\triangle$ MVErisk & 90 & .232 & .060 & .502 & 36 & .066 & -.005 & .276 & $1.871^{*}$ & 1368 \\
\hline
\end{tabular}

"*" significant at the 0.01 level (2-tailed) " significant at the 0.05 level (2-tailed) "significant at the 0.10 level (2-tailed) where:

ROA = renum on total average assets

$\mathrm{ROE}=$ retum on total average equity

$\triangle M V E$ percentage change in total market value of common equity, adjusted for dividends

$\triangle M V E r i s k$ = percentage change in total market value of common equity, adjusted for dividends and risk 
The results in Table 4.10 show that on average, the incorrect firms have better accounting performance but worse market performance compared to the correct firms. However, the differences in accounting performance are insignificant in all measures.

The market returns and the risk adjusted market returns show more significance in the differences, but this significance is only at best at the $5 \%$ level (2-tailed). The unadjusted and risk adjusted market returns in 2000 are significantly better in the correct firms [ $t$ statistics of 2.247 and 2.248 respectively]. Of lesser significance (at the $10 \%$ level) are the average unadjusted and risk adjusted market returns [t statistics of 1.662 and 1.871 respectively] and the risk adjusted market return in 1999 [t statistic 1.845].

Overall these results provide some evidence that the firms identified as incorrect in their compensation contract choice have lower performance compared to those firms making the correct choice. However, the significance of these results is low, and is limited only to the market performance metrics, so the results should be interpreted with care.

The results in Table 4.10 include no controls for other potential determinants of firm market performance. As in the prior section (Table 4.4), sensitivity testing is performed on the two average market performance measures - Ave $\triangle \mathrm{MVErisk}$ and Ave $\triangle \mathrm{MVE}$ - by estimating an ordinary least squares (OLS) regression that includes controls for firm size and growth options. The results are reported in Table 4.11 . 


\section{TABLE 4.11 - SUMMARY OF THE OLS REGRESSION COEFFICIENTS FOR THE RELATION BETWEEN FIRM PERFORMANCE, CORRECT/INCORRECT GROUP MEMBERSHIP AND Performance CONTROLS:}

The coefficients are based on the following equation: Perf ${ }_{i f}=\eta_{0}+\eta_{1}$ Group memb $_{n}+\eta_{2}$ Size $_{i t-1}+\eta_{3} \mathrm{MktBk}_{\text {ir-I }}+\varepsilon_{1 \text {. }}$. The $t$ statistics are reported in brackets.

\begin{tabular}{|c|c|c|c|}
\hline \multirow[t]{2}{*}{ Variables: } & \multirow{2}{*}{$\begin{array}{c}\text { Predicted } \\
\text { sign }\end{array}$} & \multicolumn{2}{|c|}{ Firm performance } \\
\hline & & $\begin{array}{c}\text { Ave } \triangle \mathrm{MVE} \\
\mathrm{n}=210\end{array}$ & $\begin{array}{c}\text { Ave } \triangle \text { MVErisk } \\
n=138\end{array}$ \\
\hline Intercept & $+1-$ & $\begin{array}{c}2.916 \\
\left(4.881^{* * *}\right)\end{array}$ & $\begin{array}{c}1.718 \\
\left(3.734^{* * *}\right)\end{array}$ \\
\hline Group memb $_{i f}$ & - & $\begin{array}{c}-.216 \\
\left(-2.027^{* *}\right)\end{array}$ & $\begin{array}{c}-.202 \\
\left(-2.309^{* *}\right)\end{array}$ \\
\hline Size $_{r-1}$ & - & $\begin{array}{c}-.121 \\
\left(-4.076^{* * *}\right)\end{array}$ & $\begin{array}{c}-.066 \\
\left(-2.965^{* * *}\right)\end{array}$ \\
\hline $\mathrm{MktBk}_{t-1}$ & + & $\begin{array}{l}-.0549 \\
(-.385)\end{array}$ & $\begin{array}{l}-.026 \\
(-.294)\end{array}$ \\
\hline Adjusted $R^{2}$ & & .082 & .071 \\
\hline$F$ ratio & & $6.574 * * *$ & $4.167^{* * *}$ \\
\hline
\end{tabular}

\footnotetext{
*** significant at the 0.01 level (2-tailed). ** significant at the 0.05 level (2-tailed)

* significant at the 0.10 level (2-tailed) Where:

Perf Firm performance as described in table above

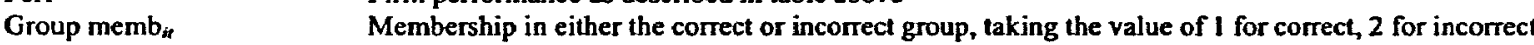

Sizer.j Membership in either the cor
Log of market value of equit

$\mathrm{MktBk}_{\mathrm{r}-1}$ Market-to-book ratio
}

The results in Table 4.11 support those in Table 4.10, and the significance of the results is improved. As predicted, the Group Membership variable is negative and significant (at the $5 \%$ level) for both models, with $t$ statistics of -2.027 for the average market return model and -2.309 for the risk adjusted market retum model. This result implies that the incorrect firms' performance is significantly lower than that of the firms choosing the correct compensation structure. The control variable of firm size is also significant and in the predicted direction [ $\mathrm{t}$ statistics of $-\mathbf{4 . 0 7 6}$ for the market return model and -2.965 for the risk adjusted market return model]. That is, smaller firms tend to have significantly better market returns. However, the market-to-book control is in the opposite direction to that predicted, but is not significant in determining either of the 
performance metrics [t statistics of -.0549 and -.026 for each model]. However, there is endogeneity in these tests as both of the control factors are also predicted to determine compensation contract choice, which means that the independent variables are not necessarily independent of each other, potentially violating one of the OLS regression assumptions and thus confounding the results.

\subsection{IMPLICATIONS OF FINDINGS}

Chapter Three provided evidence that although firms in the same industry use different types of compensation structures, there are other significant differences across the firms that could indicate that these firms are making efficient choices in their compensation designs.

This Chapter first investigates the performance consequences of the different structures, and investigates two possible predictions for the use (or non use) of equity-based compensation. The first prediction is that if firms are making efficient structure choices, then there would be no systematic differences in the performance across firms. The alternative prediction is that equity-based compensation is important in aligning the interests of management with the shareholders, and thus the use of equity-based compensation could improve firm performance. This Chapter finds no systematic difference in performance across firms using different types of compensation structures. This result could indicate that firms, on average, are using efficient contracts. 
The Chapter also investigates the performance consequences of different equity grants specifically different option terms, exercise prices and whether or not hurdles are used. The findings indicate that only the use of performance hurdles has some consistent (but weak) association with accounting measures of firm performance, where firms that use option hurdles have higher ROA and ROE compared to the firms that do not use option hurdles. However, there is no difference in the market measures of performance for the use of hurdles.

Consequently, this Chapter first provides evidence that is consistent with Chapter Three, in that firms appear, on average, to be making efficient choices in their CEO compensation structures. The Chapter goes on to further investigates these findings, by developing a predictive model for the efficient compensation structure choice for firms, based on the underlying economic characteristics of the firms. The performance consequences of deviations from the predicted compensation structure are investigated with the hypothesis that if the predictive model is accurate, then deviations from the efficient structure could result in lower firm performance, compared to firms that make the efficient choice. The multivariate results in Table 4.11 of this Chapter provide some (although weak at the $5 \%$ level) evidence that the firms using the incorrect compensation structure have lower market performance compared to those firms making the correct choice. 


\section{CHAPTER 5}

\section{CONCLUSIONS}

This thesis has expanded on current knowledge by providing evidence on the use and performance consequences of different CEO compensation structures. Specifically, this thesis has explored a setting where greater variation in the CEO compensation contract is observed, in that some firms only offer cash-based compensation to their CEOs, while others offer both cash- and equity-based compensation.

There were two main motivations for the thesis. First, theoretical literature has suggested that differences in firm characteristics could lead to differences in CEO compensation structure [Demsetz and Lehn (1985), Smith and Watts (1992), Gaver and Gaver (1993), Core, Holthausen and Larcker (1999), Bushman and Smith (2001)]. However, the existing literature has not explored differences in CEO compensation structures. The second motivation was that while both Australian regulators and investors have expressed interest in CEO compensation practices, there has been very little academic research into Australian CEO compensation.

Chapter Two has provided descriptive evidence on the variation in compensation structures observed in the Australian market, as well as evidence on the links between firm characteristics and the levels of CEO compensation awarded. Specifically, Chapter Two has demonstrated that around one-third of the largest Australian firms do not offer their CEO any equity-based compensation at all, which is very different to the well 
documented but relatively homogeneous compensation structure observed in the United States. Chapter Two also has revealed that significant variation exists in the equity granting practices, again different to that commonly observed in the United States [Murphy (1999)].

Chapter Three has investigated whether firms using different compensation structures have different underlying economic characteristics. One explanation for the lack of use of equity-based compensation by some firms [the cash group] in the Australian market could be that these firms are inefficient in their contract choices. If the cash group firms are inefficient, then there could be no difference in their underlying economic characteristics compared to the equity group firms. Alternatively, the observed variation could be efficient, in which case there could be significant differences, on average, in the economic characteristics of the firms in the cash group compared to the equity group. Chapter Three has provided evidence that on average, there are significant differences in the economic characteristics of the firms in the two compensation groups. Specifically, Chapter Three has found that firms in the equity group are larger, are more decentralised, have more growth options, and lower CEO share ownership. Thus Chapter Three has expanded on the existing research by demonstrating that it could be efficient for firms with different economic characteristics to use different compensation structures.

Chapter Four has examined the performance consequences of the use of different compensation structures. Two possible expectations for the link between the type of 
compensation contract and firm performance have been investigated. On one hand, many studies have argued that management's incentives are more closely aligned with those of shareholders when management receive some sort of equity-based compensation, and thus imply that firm performance should be better in firms using equity-based compensation compared to those firms that do not [Holmstrom (1979), Harris and Raviv (1979), Grossman and Hart (1983), Smith and Watts (1982), Smith and Stultz (1985), Hirshleifer and Suh (1992) and Shleifer and Vishney (1997)].

On the other hand, others have argued that compensation contracts should be set dependent on the underlying economic characteristics of the firm, and these studies imply that it could not be efficient for all firms to provide equity-based compensation [Demsetz and Lehn (1985), Lambert and Larcker (1987), Banker and Datar (1989), Smith and Watts (1992), Gaver and Gaver (1993), Core, Holthausen and Larcker (1999), Datar, Kulp and Lambert (2001), Bushman and Smith (2001)]. If all compensation contracts are set efficiently then there should be no cross-sectional differences in firm performance [Core, Holthausen and Larcker (1999), Ittner, Lambert and Larcker (2003)]. First, Chapter Four has found little evidence of systematic differences in firm performance across the two compensation contract groups. This result has confirmed that on average, firms offer an efficient compensation structure to their CEOs. Second, Chapter Four constructed a model that attempted to describe the efficient compensation structure, based on the economic characteristics of the firms. Then the performance of firms deviating from their predicted compensation structure has been compared to that of the firms making the "correct" compensation structure choice. The prediction for this 
test was that firms using "incorrect" CEO compensation structures should have lower firm performance compared to those that use an efficient or "correct" structure. The evidence of Chapter Four was that firms in the incorrect compensation group have lower firm performance compared to firms in the correct group, although these findings are only confirmed at the $5 \%$ level.

Overall, this thesis has provided important new insights into CEO compensation structure choice. The first motivation for the thesis was to investigate the theory that firms with different economic characteristics could choose different compensation structures, and the results have supported this theory. Further, the thesis has provided evidence that lower firm performance is associated with incorrect compensation structure choice.

The second motivation for this thesis was the current public policy debate, and to provide research evidence on Australian CEO compensation practices and firm performance. As noted in Chapter One, of particular interest to the popular press has been the level of compensation awarded to the CEO, and the links between CEO compensation and firm performance. The results of this thesis have indicated that both the levels and structure of CEO compensation differ across firm characteristics, and that this variation could be efficient. Thus variation in CEO compensation design could be expected, rather than a "one-size-fits-all" model, as implied by some of the press articles cited through the thesis. Further, while the popular press have concentrated on levels of CEO compensation and whether or not higher levels of pay are related to firm 
performance, the performance results in Chapter Four suggest that more attention could be paid to CEO compensation structure - that firm performance suffers where firms make incorrect compensation structure choices.

There a number of implications for further research from this work. First, this thesis only has a small sample to use to test the economic characteristics of firms offering different types of equity-based compensation. Chapter Four illustrates that there is little variation in performance across these firms, which could suggest that their choices are efficient. More analysis into the differences in their economic characteristics would provide interesting evidence on the choices made. Second, due to data limitations ${ }^{1}$, this thesis does not test the different types of hurdles in place and there link to firm characteristics and performance. Third, the existence of accounting-based hurdles and earnings management could be investigated. Fourth, this thesis has made no attempt to proxy for the CEO's preferences, which could be a factor in determining the efficient compensation choice, and could be studied. Finally, the predictive model used in Chapter Four identified firms that could be using the "incorrect" compensation structure. Reasons for this deviation, such as board composition, could also be studied. However, despite the limitations, this thesis provides new insights into CEO compensation structure and firm performance.

\footnotetext{
' Full hurdle details are a voluntary disclosure in the financial statements, and as not all firms made this disclosure the sample with full details is extremely small in this data set.
} 
APPENDIX 1.A:

THE "UTS-ACCENTURE Who Governs Australia" DataBase

\section{-DATA DicTIONARY}

1. Company Information

$\begin{array}{ll}- & \text { Company name } \\ - & \text { ASX Code } \\ - & \text { Industry code and sub-industry code } \\ - & \text { Year end date } \\ - & \text { First list date }\end{array}$

2. CEO and Top Five Executives

- name

- $\quad$ Age / date of birth

- date of appointment

- date of resignation

- $\quad$ length of service

- $\quad$ highest qualification

- $\quad$ ranked qualification (drop down)

- text field to record the qualification details e.g. subject name

3. For Each Director on the Board

- $\quad$ Name of director

- Affiliation given by annual report (executive / nonexecutive)

- $\quad$ Role of director on the board

- Details of all related party transactions

- Date of appointment

- Date of resignation

- Qualifications

- $\quad$ ranked qualification (drop down)

- text field to record the qualification details e.g. subject name

- $\quad$ Other directorships

- Membership on board sub-committees:

- $\quad$ Audit

- Remuneration

- Nomination

- Others

- $\quad$ Meetings held while a director

- Meetings attended while a director

- Number of other board directorship 
4. Compensation (for each CEO / Executive / Directors)

- Total salary

- $\quad$ Base salary

- $\quad$ Cash bonus

- Other compensation

- $\quad$ For each equity based compensation grant:

- number of equity given

- date approved

- date given

- annual report value

- $\quad$ calculated value

- $\quad$ calculated method

- $\quad$ exercise price

- $\quad$ exercise date

- $\quad$ hurdles attached

- $\quad$ valuation and method

5. Shareholding (For each CEO / Executive / Director)

Nominal shareholding for each equity type:

- Preference shares

- Options

- Ordinary Shares

- Others

Beneficial shareholding for each equity type:

- Preference shares

- Options

- Ordinary Shares

- Others

6. Auditors

7. Shareholders

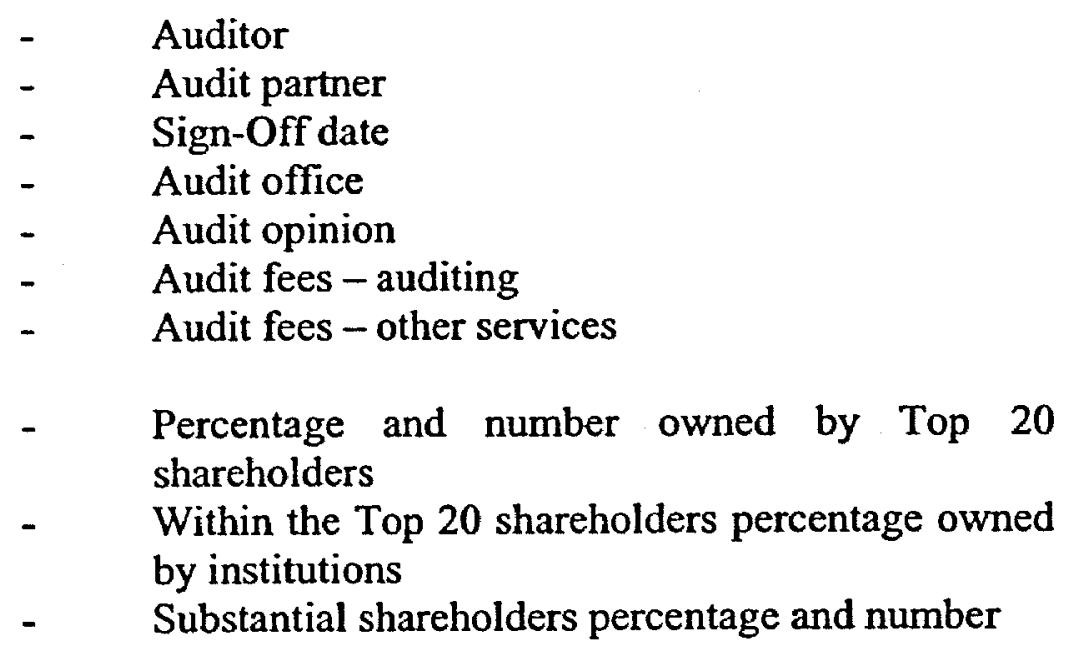


8. Consolidated Financials (P\&L)

$\begin{array}{ll}- & \text { Rounding } \\ \text { - } & \text { Total sales } \\ \text { - } & \text { Total operating income before tax } \\ \text { - } & \text { Total income after tax } \\ \text { - } & \text { Total income after tax and extraordinary items } \\ \text { - } & \text { Dividends in P \& L for year } \\ \text { - } & \text { R \& D expense if given } \\ \text { - } & \text { Earnings per share } \\ & \text { - } \quad \text { Diluted } \\ \text { - } \quad \text { Basic } \\ \text { - } \quad \text { Efferest Expense } \\ \text { - } \quad \text { Profit attributable to OEI } \\ \text { - } \quad \text { Depreciation charges } \\ \text { - } \quad \text { Amortisation charges } \\ \text { - } \quad \text { Tax Expense }\end{array}$

9. Consolidated Financials - (Balance Sheet)

$$
\begin{array}{ll}
- & \text { Rounding } \\
- & \text { Total equity } \\
\text { - } & \text { Total Assets } \\
\text { - } & \text { Long term debt } \\
\text { - } & \text { Total liabilities } \\
- & \text { OEI }
\end{array}
$$

10. Consolidated Financials - (Cash Flow statement)

$$
\begin{array}{ll}
- & \text { Rounding } \\
- & \text { Operating cash flow } \\
- & \text { Cash used in investing } \\
- & \text { Cash from financing } \\
- & \text { Dividends paid during year } \\
- & \text { Tax paid } \\
-\quad & \text { Opening balance of Cash } \\
- & \text { Closing balance of cash }
\end{array}
$$

11. Financial statements - Other

- Number of subsidiaries

- $\quad$ Number of foreign subsidiaries

- $\quad$ For each of the equity type issued (Ordinary, Pref. Shares, Options, Others):

- Number issued

- Class name

- For each of the equity type, the distribution of shareholders:

- $\quad$ Start and End Range 


\section{- Number of shareholders}

12. Stock market characteristics

- $\quad$ Dividends per share paid in year

- $\quad$ Stock returns over year

- Monthly stock return variance for sixty-month period proceeding option award date

- Share price at end of month for 3 months following year end

- $\quad$ Share price at year end

- Beta of company at year end

- $\quad$ Annualised Risk free rate

- $\quad$ Annualised Market Return 


\section{APPENDIX 2.A: \\ THE VALUATION OF EXECUTIVE AND EMPLOYEE STOCK OPTIONS}

The most common method used to value executive and employee stock options in the literature to date is the Black and Scholes (1973) and Merton (1973) methodology [the Black-Scholes model] [Stoddard (2001)]. However, the Black-Scholes model was initially developed for the pricing of European call options, and is based on a number of assumptions such as the ability of the option holder to diversify risk by hedging, constant dividend yields and stock-price volatilities, and exercise only on expiry date. These underlying assumptions have led various academics to question this model's ability to correctly value executive and employee stock options.

Murphy (1999) argues that the Black-Scholes model assumptions of constant dividend yields and stock-price volatilities are more applicable to short-term traded options (those expiring in 6 months or less), compared to executive options that can expire in a decade. Further, Murphy (1999) suggests that executive stock options are usually subject to forfeit if the executive leaves the firm prior to vesting, and the probability of forfeiture reduces the cost of granting the option (to the firm) and thus overstates the option values [also a criticism raised in Frye (2001)]. Murphy (1999) also criticises the Black-Scholes model assumption that options can only be exercised at the expiration date, while executive options can be exercised immediately on vesting, which typically occurs early in the option's term. This opportunity to exercise early has ambiguous implications for the cost of the option - the right to exercise early increases the value of the option, but 
risk-averse executives tend to exercise much earlier than a risk neutral rational investor, and the early exercise reduces the cost of the option.

Maller, Tan and van de Vyver (2002) argue that there are two reasons why the standard Black-Scholes model could be an inappropriate method to value executive stock options. First, they state that the Black-Scholes model is only accurate when the wealthmaximising strategy of the option holder is to hold the options until the expiry date, while an executive could not hold the option until expiry due to diversification or liquidity reasons. Second, Maller, Tan and van de Vyver (2002) argue that the BlackScholes model assumes that the option holder can diversify risk, and that a risk less strategy results in a single option price that all market participants will agree is a "fair market value". However, with executive stock options, neither the executive nor the firm ' can hedge all of their risk. As neither party to the option contract can diversify all risk, Maller, Tan and van de Vyver (2002) argue that neither party will arrive at the same value for the option (although they will be able to arrive at their own values for the option) [also raised by Core and Guay (2001)].

This difference in option value between the firm and the executive was raised in earlier work by Lambert, Larcker and Verrecchia (1991). They argued that if a risk-averse manager has a significant portion of his wealth tied to the firm's stock price, then his value of an option compensation contract could be substantially less than its cost to the

\footnotetext{
'The authors suggest that the unhedgeable risks faced by the firm include employee resignation or takeovers
} 
firm $^{2}$. Consequently, another valuation issue that arises is whether the executive option should be valued from the firm's or the executive's point of view ${ }^{3}$.

Brown and Yew (2002) also identify an additional issue, specifically applicable in valuing Australian executive options - that of the performance hurdles that are attached to many of the grants. They argue that the existence of hurdles introduce difficult valuation issues, especially when the hurdle is something other than stock price ${ }^{4}$. As Cullen Egan Dell (1997) find that the most common hurdle used in Australian options is EPS, incorporating the performance hurdle when valuing these types of options is problematic.

In support of using the Black-Scholes model, Stoddart (2001) argues that the dividend modified Black-Scholes model produces reasonable estimates of executive option value when the dilution effect is small (as this model is designed to be used where the underlying instrument has already been issued and the exercise of the option will not result in a flow of money into the company). However, ignoring the dilution effect produces an upwards bias in the results and if the number of employee options exceeds $15 \%$ of the issued capital, then the dilution effect is likely to be significant and standard

\footnotetext{
${ }^{2}$ Meulbroek (2001) attempts to derive a method to measure the difference in option values to the firm and the employee, and shows that this difference can be quite large, particularly in growing firms. She shows that an undiversified manager in an internet-based firm values their option-based compensation at an average of $53 \%$ of the cost to the firm, and if that manager can partially diversify (holding around $50 \%$ of their assets in the market portfolio), the value increases to around $59 \%$ of the cost to the firm. In contrast, an undiversified NYSE firm manager will value the compensation at anound $70 \%$ of the cost to the firm.

${ }^{3}$ It could also be argued that due to the differences in the tax rates paid in Australia between companies and individuals, even the cost to the firm of the cash portion of salary is different from the value placed on it by the executive. However, it would also only be in very rare situations that the gap between the cost and value of cash salary differed across firms and individuals.

'When the hurdle is related to the firm's stock price, the Maller, Tan and van de Vyver (2002) UWA modified binomial valuation technique can be used to arrive at a value for the options.
} 
dilution adjustments should be made ${ }^{5}$. Further, Stoddart (2001) also states that Cheung and Marsden (1998) have shown that the Black-Scholes model is likely to over-value the options where they are deeply out of the money, in which case the binomial models will give a better estimate.

Given the problems identified in using the Black-Scholes model to value executive options, researchers have attempted to determine other modelling approaches to determine the value of an executive option. For example, Lambert, Larcker and Verrecchia (1991) ${ }^{6}$ develop a structural model that measures the executive's utilitymaximising behaviour. This model assumes that the executive exercises the options so as to maximise their expected utility, subject to hedging restrictions. However, this model requires various proprietary information, such as the executive's private wealth, risk aversion, diversification desires, liquidity requirements and potential gains from voluntary resignation.

Maller, Tan and van de Vyver (2002) develop a model specifically for Australian executive options by extending the binomial valuation model to accommodate different performance vesting criteria (or performance hurdles) and forfeiture conditions [named the UWA model]. Brown and Yew (2002) use both the UWA model and the BlackScholes model in their empirical paper, and find that the Black-Scholes and UWA models give highly consistent results. Further, Brown and Yew (2002) state that the

\footnotetext{
Stoddart (2001) also reviews the binomial models, developed for American options, and can be adapted for situations where the exercise price increases over time or is indexed. However, she argues that these models also require adjustment where options over unissued shares exceed $15 \%$ of the issued capital.
} 
UWA model did not deal with performance hurdles based on anything other than the firm's stock price. Consequently, where the hurdle depended on the investment performance of a basket of stocks, or when the hurdle was an accounting number, the UWA model gave imprecise executive option valuations.

\section{Valuation techniques used in the literature to date}

As previously stated, the most common method used in the literature to value executive options is the Black-Scholes model, modified for dividend payments [used by Murphy (1985), Jensen and Murphy (1990), Gibbons and Murphy (1990) [in that they use the Murphy 85 data set], Mehran (1995), Angbazo and Narayanan (1997), Murphy (1999), Guay (1999), Frye (2001), Ryan and Wiggins (2001) ${ }^{7}$, Core and Guay (2001), Brown and Yew (2002)].

Other methods that have been used to value executive options include $25 \%$ exercise price [Core, Holthausen and Larcker (1999), Coulton and Taylor (2002a)]; discounted expected gain approach ${ }^{8}$ where options are valued with an assumed annual stock price growth of $15 \%$, a 5 year holding period before the option is exercised and a risk-free rate of 5\% [Ittner, Lambert and Larcker (2002)]; binomial valuations [Aboody (1996), Hermalin and Wallace (2001)], and modified binomial valuations such as the UWA model [Brown and Yew (2002)].

\footnotetext{
Also see Huddart (1994) and Hall and Murphy (2000)

7 Ryan and Wiggins (2001) use ExecuComp data that value options using the modified Black-Scholes model.

iQuantic data values stock options using this method.
} 
Ittner, Lambert and Larcker (2003) argue that the discounted expected gain approach is an unsophisticated approach to valuing the options, but justify its use by stating that firms themselves mostly use simple methods to value the options that they provide to their CEOs. In Ittner, Lambert and Larcker's (2003) sample, the Black-Scholes model is used by $22.5 \%$ of firms, $23.5 \%$ use the present value of the expected gain, $18 \%$ use strike price by number of options granted, $4 \%$ use some other model and $32 \%$ do not use any valuation model at all.

In using $25 \%$ of exercise price, Core, Holthausen and Larcker (1999), state that simulation models by Lambert et al (1991) and McConnell (1993) suggest that the more sophisticated option pricing models (based on the Black-Scholes or binomial formulas) produce values in the $25 \%$ of exercise price range. Brown and Yew (2002) find that the modified binomial valuation technique developed for valuing Australian options [the UWA model] also provides values very similar to that produced by the Black-Scholes model.

Given the similarities in values obtained valuing options using the Black-Scholes model, $25 \%$ of exercise price, binomial models and the UWA model, this thesis follows the majority of literature to date and values options granted using the dividend modified Black-Scholes model ${ }^{9}$. It is acknowledged that the Black-Scholes model provides

\footnotetext{
'However, following Stoddart (2001), dilution effects are checked, as too are any options deeply out of the money [Cheung and Marsden (1998)]
} 
biased estimates because of its assumptions of risk neutrality of the option holder and exercise only on expiry date; that it is more applicable to short term options due to the assumptions of constant dividend yields and stock-price volatilities [Murphy (1999)]; and its inability to deal with attached performance hurdles. 
Option Valuation Model - the Black-Scholes

The Black-Scholes model, modified to adjust for dividends used in this thesis takes the following functional form ${ }^{10}$ :

$$
\text { OptionValue }=P e^{-\ln (1+d) t} N(z)-X e^{-\ln (1+r) T} N(z-\sigma \sqrt{T)}
$$

where:

$\mathrm{P}=$ Grant-date stock price

$\mathrm{X}=$ Exercise price

$\mathrm{T}=$ Expiration term (in years)

$\mathrm{D}=$ Annualised dividend yield

$\sigma=$ Annual stock-price volatility

$\mathbf{r}=$ Risk-free interest rate

$z=\frac{\ln (P / X)+\left(\ln (1+r)-\ln (1+d)+\sigma^{2} / 2\right) T}{\sigma \sqrt{T}}$

$\mathrm{N}()=$ Cumulative normal distribution function

${ }^{10}$ The model used here is consistent with that used by Murphy (1999) 


\section{APPENDIX 2.B: \\ Firm CHARACTERISTICS AND THE LEVEL OF CEO COMPENSATION:}

Chapter Two reveals that the level of CEO compensation varies across industry and compensation group membership, and academic research has argued that the optimal level of CEO compensation packages could vary across firms, dependent on the underlying economic characteristics of the firm [Jensen and Meckling (1976), Core, Holthausen and Larcker (1999)]. The objective of this Appendix is to provide further explanation of the variation in the level of CEO compensation awarded by comparing levels of CEO compensation to the various determining firm characteristics suggested by the prior literature, as well as improving on the research designs used in the prior literature.

There is some existing evidence on the link between firm characteristics and the level of CEO compensation. For example, using a large sample of firms over the years 1992 to 1996, Murphy (1999) shows that the level of CEO compensation is linked to firm size and industry. Murphy does not test any other firm characteristics, and thereby limits the evidence in his study. Core, Holthausen and Larcker (1999) investigate more economic characteristics (such as growth options, firm risk and performance) and provide further evidence on the links between firm characteristics and compensation levels. However, their sample size is limited to 495 observations for 205 firms over 1982 to 1984, which could limit the current applicability of their results. Further, while Core, Holthausen and Larcker (1999) build an argument that both firm size and firm complexity could drive levels of CEO compensation, they use total sales to proxy for both of these firm 
characteristics. Finally, Core, Holthausen and Larcker (1999) do not include any measure of current firm performance, even though it would be expected to influence the level of total compensation.

This Appendix builds on the current literature by testing all of the firm characteristics suggested by Murphy (1999) and Core, Holthausen and Larcker (1999), as well as improving on Core, et al's research design by using a separate proxy for firm complexity, and proxies for current firm performance.

\section{Theory Development}

Jensen and Meckling (1976) suggest that the level of CEO compensation is set to minimise agency costs and maximise firm value. Following the traditional agency perspective, Core, Holthausen and Larcker (1999) state that shareholders choose a CEO compensation contract in order to maximise firm value based on the firm's information environment, and its demand for quality in the CEO. They therefore argue that if there is optimal CEO contracting, the economic determinants of the levels of CEO compensation would describe all of the cross-sectional variation in CEO compensation observed. Further, they suggest that the economic determinants that drive the level of CEO compensation are those that determine the level of quality required in the CEO, and the relative quality of the CEO, in turn, determines the level of compensation, with higher quality CEOs demanding higher compensation. 
In identifying the firm characteristics that drive the level of quality required in the CEO, Core, Holthausen and Larcker (1999) cite Rosen (1982) and Smith and Watts (1992), who predict that larger firms, firms with more growth opportunities and firms with more complex operations demand higher quality CEOs and therefore pay higher compensation. Past firm performance is also suggested to determine the level of CEO compensation, as Jensen and Murphy (1990), Hermalin and Weisbach (1998) and Hermalin and Wallace (2001) argue that future salaries increase in response to good firm performance. Firm risk is also included as a determinant of CEO compensation, following the arguments of Banker and Datar (1989) that compensation risk (and thus the level of compensation) could either increase or decrease with firm risk. Consequently, they predict that larger firms, firms with more growth opportunities and firms with more complex operations and better past performance demand higher quality CEOs and therefore pay higher compensation.

However, although firm characteristics could drive compensation contract choice, optimal contracting might not be observed within all firms at all times. Core, Guay and Larcker (2003) argue that optimal compensation contracting arrangements evolve over time as firms experiment with new types of incentive contracts and update their beliefs about optimal incentive levels, although they could still be uncertain as to the optimal contract $^{11}$. Milgrom and Roberts (1992) also state that in compensation contracting,

\footnotetext{
"In addition, transactions costs reduce the opportunities for firms to continuously re-contract until an optimal solution is found. Core, Guay and Larcker (2003) state that one main difference between the efficient and inefficient contracting views are in the treatment of the transactions costs required to correct sub-optimal contracts. They argue that an implicit assumption of inefficient contracting is that the transactions costs are so great that firms cannot re-contract when inefficiencies arise, while efficient contracting assumes that there are no transactions costs at all, and that fims can continuously re-contract ffor example, see Demsetz and Lehn (1985)]
} 
people learn over time, and organisations adapt by experimentation and imitation. Consequently, Core, Guay and Larcker (2003) imply that due to the uncertainty and differences in beliefs in optimal contracting arrangements, compensation contracting periodically becomes misaligned within firms, and thus both efficient and inefficient contracting is observed in cross-section. However, unless the uncertainty and differences in beliefs are systematically biased, compensation contracts are efficient, on average [Core, Guay and Larcker (2003)]. If the contracts are efficient on average, the underlying economic characteristics of the firm that determine the level of quality required in the CEO would explain the cross-sectional variation in the observed levels of CEO compensation contracts.

Alternatively, CEO compensation contracting might not be efficient on average, but it may more represent rent extraction [Bebchuk, Fried and Walker (2002)]. In this case, the levels of CEO compensation would not be related to the underlying economic characteristics of the firm.

This Appendix adopts the traditional agency perspective, and expects that on average, the levels of CEO compensation are set based on the underlying economic characteristics of the firm that determine the relative demand for quality in the CEO. Thus it is predicted that: 
$\mathrm{H}_{1}$ - The level of CEO compensation is related to the underlying economic characteristics of the firm that determine the relative demand for quality in the CEO.

The sample for this Appendix is the same as that used in Chapter Two, and the sample selection process is described in section 2.3 of Chapter Two.

\section{Research Design}

As discussed above, it is predicted that larger firms, firms with more growth opportunities and firms with more complex operations will demand higher quality CEOs and therefore pay higher compensation. This Appendix proxies for firm size with the $\log$ of the market value of equity, growth opportunities with the market to book ratio and firm complexity with the log of total subsidiaries and the $\log$ of total foreign subsidiaries.

Past firm performance is also suggested to determine the level of CEO compensation and firm performance is measured using both share returns and return on assets. Firm risk is also included as a determinant of CEO compensation, and is measured as the standard deviation of return on assets over the prior three years. Finally, current performance is also expected to impact on CEO compensation, and two measures of current performance are included - ROA and market return (adjusted for dividends). 
As these firm characteristics are expected to determine the firm's relative demand for a certain level of quality in their CEO and consequently the level of compensation at the beginning rather than at the end of the financial period, these factors are ex ante predictors of the level of the compensation. Consequently, all economic characteristics are measured during the year prior to that in which the level of compensation is measured, except for current performance. The summary of the definitions and measurements of the variables used to proxy for the firm's economic characteristics are described in Table 2.B.1 below: 
Table 2.B.1 - Economic characteristics of the firm that determine the level of CEO compensation

\begin{tabular}{|c|c|c|c|}
\hline Variable & $\begin{array}{c}\text { Predicted } \\
\text { sign }\end{array}$ & Variable name & Proxy used \\
\hline Size & + & $\operatorname{Size}_{t-1}$ & $\begin{array}{l}\text { Log of the market value of } \\
\text { equity }\end{array}$ \\
\hline Past Performance & $\begin{array}{l}+ \\
+ \\
+\end{array}$ & $\begin{array}{l}\operatorname{Perf}_{t-1}{ }^{\mathrm{R}} \\
\text { Perf }_{t-1}^{\mathrm{ROA}}\end{array}$ & $\begin{array}{l}\text { Prior year share return, } \\
\text { dividend adjusted } \\
\text { Prior year Return on Assets } \\
\text { (ROA), measured as EBIT } \\
\text { divided by the average book } \\
\text { value of assets }\end{array}$ \\
\hline $\begin{array}{l}\text { Growth } \\
\text { opportunities }\end{array}$ & + & $\mathrm{MktBK}_{t-1}$ & Market-to-book ratio \\
\hline Risk & $+1-$ & $\operatorname{Risk}_{t-x}$ & $\begin{array}{l}\text { Standard deviation of } \mathrm{ROA} \\
\text { over prior } 3 \text { years }\end{array}$ \\
\hline Complexity & $\begin{array}{l}+ \\
+\end{array}$ & $\begin{array}{l}\text { Complex }_{t-I}^{\text {sub }} \\
\text { Complex }_{t-I}^{\text {subfor }}\end{array}$ & $\begin{array}{l}\text { Log of number of subsidiaries } \\
\text { Log of number of foreign } \\
\text { subsidiaries }\end{array}$ \\
\hline $\begin{array}{l}\text { Current } \\
\text { Performance }\end{array}$ & $\begin{array}{l}+ \\
+\end{array}$ & $\begin{array}{l}\text { CurrPerf }_{t}^{\mathrm{SR}} \\
\text { CurrPerf }^{\mathrm{ROA}},\end{array}$ & $\begin{array}{l}\text { Current year share return, } \\
\text { dividend adjusted } \\
\text { Current year Return on Assets } \\
\text { (ROA), measured as EBIT } \\
\text { divided by the average book } \\
\text { value of assets }\end{array}$ \\
\hline
\end{tabular}

In order to test the relation between the levels of CEO compensation and the predicted firm characteristics, the following cross - section regression is estimated using Ordinary Least Squares (OLS): 


$$
\begin{aligned}
& \text { TotalComp }_{i t}=\eta_{0}+\eta_{1} \text { Size }_{i t-1}+\eta_{2} \operatorname{Perf}^{\mathrm{SR}}{ }_{i t-1}+\eta_{3} \operatorname{Perf}^{\mathrm{ROA}}{ }_{i t-1}+\eta_{4} \mathrm{MktBk}_{i t-1}+\eta_{5} \\
& \operatorname{Risk}_{i t-1}+\eta_{6} \text { Complex }^{\mathrm{sub}}{ }_{i t-1}+\eta_{7} \text { Complex }_{i t-1}^{\text {subfor }}+\eta_{8} \operatorname{CurrPerf}^{\mathrm{SR}}+ \\
& \eta_{9} \operatorname{CurrPerf}^{\mathrm{ROA}}{ }_{i t}+\varepsilon_{\mathrm{I} .}
\end{aligned}
$$

Where:

TotalComp $_{i t}=$ natural $\log$ of total compensation awarded to the CEO in the year, using lagged bonuses and valuing option grants using Black-Scholes

Other variables $\quad=$ as per Table 2.B.1 above

The regression is tested first on both the pooled sample, and the industry sub-samples as Core, Holthausen and Larcker (1999) suggest that there could be differences across industries for the demand for and supply of managerial talent, that can affect the equilibrium wage.

\section{Descriptive results:}

Table 2.B.2 shows the overall sample distributions of the firm characteristics identified as being relevant to the level of CEO compensation for the total sample and for the cash and equity groups separately. Due to missing data, the overall sample is reduced to 672 observations, and 601 observations for the risk variable ${ }^{12}$.

\footnotetext{
${ }^{12}$ All outliers are identified using the procedure in SPSS, and are winsorised.
} 
Table 2.B.2 - Descriptive results ${ }^{13}$ :

\begin{tabular}{|c|c|c|c|c|c|c|c|c|c|c|c|c|}
\hline & \multicolumn{4}{|c|}{ Total sample } & \multicolumn{4}{|c|}{ Cash group } & \multicolumn{4}{|c|}{ Equity group } \\
\hline & $n$ & Mean & Median & Std dev & $\mathrm{n}$ & Mean & Median & Std dev & $\mathrm{n}$ & Mean & Median & $\begin{array}{l}\text { Std } \\
\mathrm{dev}\end{array}$ \\
\hline TotalComp & 672 & 13.215 & 13.122 & 1.006 & 231 & 12.761 & 12.739 & .962 & 441 & 13.453 & 13.354 & .946 \\
\hline Size $_{t-1}$ & 672 & 19.306 & 18.972 & 1.670 & 231 & 18.908 & 18.661 & 1.385 & 441 & 19.514 & 19.204 & 1.782 \\
\hline $\operatorname{Perf}_{t-1}^{\mathrm{SR}}$ & 672 & .313 & .023 & 1.35 & 231 & .199 & -.013 & 1.087 & 441 & .3733 & .076 & 1.470 \\
\hline $\operatorname{Perf}_{1-1}{ }^{R O A}$ & 672 & .0234 & .056 & .199 & 231 & .060 & .063 & .138 & 441 & .0042 & .050 & .222 \\
\hline $\mathrm{MktBk}_{1-l}$ & 672 & 3.148 & 1.762 & 5.223 & 231 & 2.473 & 1.623 & 2.64 & 441 & 3.501 & 1.904 & 6.121 \\
\hline Risk $_{t-x}$ & 601 & .0603 & .0211 & .114 & 209 & .062 & .024 & .115 & 392 & .0592 & .020 & .114 \\
\hline Complex $^{\text {sub }}{ }_{1-1}$ & 672 & 1.847 & 2.602 & 3.51 & 231 & 1.472 & 2.303 & 3.568 & 441 & 2.044 & 2.708 & 3.367 \\
\hline Complex ${ }_{t=1}^{\text {subfor }}$ & 672 & -2.275 & .6932 & 5.477 & 231 & -3.715 & 0 & 5.403 & 441 & -1.528 & 1.099 & 5.371 \\
\hline CurrPerf $^{\text {SR }}$, & 671 & .1514 & .070 & .530 & 231 & .147 & .046 & .488 & 440 & .154 & .090 & .551 \\
\hline CurrPerf $^{\mathrm{ROA}}$ & 672 & .0678 & .080 & .094 & 231 & .080 & .080 & .076 & 441 & .061 & .080 & .101 \\
\hline
\end{tabular}

Where:

TotalCompir

Log of total compensation

Size, ${ }^{\prime \prime}$

Perforit

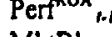

MktBk,
Risk
iox

Log of the market value of equity

Prior year share return

Prior year Return on Assets (ROA)

Prior year Retum on

Standard deviation of ROA over prior 3 years

Complex ${ }^{\text {utb }}{ }^{1, t} \quad$ Log of number of subsidiaries

Complex ${ }^{\text {aublor }}$ Log of number of foreign subsidiaries

CurrPerf ${ }^{R}$, Current year share retum

CurrPerf ${ }^{\text {RON }}$ Current year ROA

\footnotetext{
${ }^{13}$ Descriptive results of the un logged size and complexity measures can be found in Chapter Three
} 
Table 2.B.2 shows that on average, the equity group firms pay more total compensation, as expected from the descriptive results presented in Chapter Two. The equity group firms on average are also larger, have had better prior share return performance but worse prior accounting return performance, have more growth options and are more complex. In terms of current performance, both groups are relatively similar. The levels of compensation described in Chapter Two indicate that on average the equity group receives higher compensation compared to the cash group, and these descriptive results provide some possible explanation for this.

Tables 2.B.3a through 2.B.3d provide the descriptive results for the dependent variables by industry and compensation group. The descriptive evidence for the mining industry in Table 2.B.3a does not give any clear indication as to why the equity group receive higher average compensation as shown in Chapter Two: 
Table 2.B.3a - Descriptive results for the independent variables for the Mining industry by compensation group:

\begin{tabular}{|c|c|c|c|c|c|c|c|c|}
\hline & \multicolumn{4}{|c|}{ Equity } & \multicolumn{4}{|c|}{ Cash } \\
\hline & $\mathrm{n}$ & Mean & Median & $\begin{array}{l}\text { Std } \\
\text { dev }\end{array}$ & $n$ & Mean & Median & $\begin{array}{l}\text { Std } \\
\text { dev }\end{array}$ \\
\hline TotalComp $_{i t}$ & 83 & 13.066 & 13.104 & 1.018 & 41 & 12.572 & 12.677 & 1.087 \\
\hline Size $_{t-l}$ & 83 & 18.889 & 18.614 & 1.634 & 41 & 19.114 & 18.695 & 1.770 \\
\hline $\operatorname{Perf}^{S R}$ & 83 & .0925 & -.022 & .733 & 41 & .299 & -.078 & 1.706 \\
\hline $\operatorname{Perf}_{t-1}^{\text {ROA }}$ & 83 & -.092 & .011 & .269 & 41 & .032 & .046 & .128 \\
\hline $\mathrm{MktBk}_{t-1}$ & 83 & 2.270 & 1.302 & 5.321 & 41 & 2.406 & 1.51 & 2.12 \\
\hline Risk $_{t-x}$ & 74 & .052 & .021 & .073 & 36 & .051 & .028 & .064 \\
\hline Complex $_{t-1}^{\text {sub }}$ & 83 & .479 & 2.398 & 4.704 & 41 & .525 & 1.792 & 4.283 \\
\hline Complex $^{\text {subfor }}{ }_{t-1}$ & 83 & -2.797 & 0 & 5.608 & 41 & -4.689 & -9.21 & 5.492 \\
\hline CurrPerf $f^{6 R}$ & 82 & .081 & .074 & .540 & 41 & .163 & .039 & .550 \\
\hline CurrPerf $^{\mathrm{ROA}}$ & 83 & .017 & .030 & .101 & 41 & .060 & .070 & .106 \\
\hline 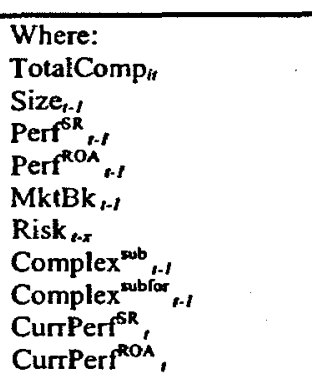 & $\begin{array}{l}\text { Log } \\
\text { Log } \\
\text { Prio } \\
\text { Prio } \\
\text { Mar } \\
\text { Stan } \\
\text { Log } \\
\text { Log } \\
\text { Cur } \\
\text { Cur }\end{array}$ & $\begin{array}{l}\text { fotal comper } \\
\text { the market } \\
\text { ear share reth } \\
\text { ear Return o } \\
\text {-to-book rati } \\
\text { rd deviation } \\
\text { number of } s \\
\text { number of f } \\
\text { t year share } \\
\text { t year ROA }\end{array}$ & $\begin{array}{l}\text { tion } \\
\text { ue of equity } \\
\text { Assets (ROA) } \\
\text { ROA over p } \\
\text { sidiaries } \\
\text { eign subsidia } \\
\text { urn }\end{array}$ & years & & & & \\
\hline
\end{tabular}

Although the equity mining firms have higher compensation, on average, it is the cash group firms that are larger, have better performance, have more growth options and are more complex when looking at the total number of subsidiaries. The cash firms also appear to have better current stock market performance. It is only when complexity is measured with total foreign subsidiaries that the equity group is higher. These descriptive results have two possible explanations. First, they could indicate the prior theorised determinants of the levels of compensation do not well explain the differences in CEO total compensation between the two compensation groups in the mining industry. For example, the types of growth options held by a mining firm might not be 
influenced by the quality of the CEO. Alternatively, the descriptive results could simply imply that the proxies used to measure the relevant firm characteristics are not good measures in the mining industry.

Table 2.B.3b provides the descriptive results for the manufacturing industry:

Table 2.B.3b - Descriptive results for the independent variables for the Manufacturing industry by compensation group:

\begin{tabular}{|c|c|c|c|c|c|c|c|c|}
\hline & \multicolumn{4}{|c|}{ Equity } & \multicolumn{4}{|c|}{ Cash } \\
\hline & $\mathbf{n}$ & Mean & Median & $\begin{array}{l}\text { Std } \\
\text { dev }\end{array}$ & n & Mean & Median & $\begin{array}{l}\text { Std } \\
\text { dev }\end{array}$ \\
\hline TotalComp $i t$ & 193 & 13.317 & 13.090 & .869 & 82 & 12.813 & 12.624 & .848 \\
\hline Size $_{t-1}$ & 193 & 19.318 & 19.026 & 1.41 & 82 & 18.580 & 18.311 & 1.315 \\
\hline $\operatorname{Perf}^{\mathrm{SR}}{ }_{t-1}$ & 193 & .291 & .040 & 1.130 & 82 & .259 & .023 & 1.188 \\
\hline $\operatorname{Perf}_{t-1}^{\mathrm{ROA}}$ & 193 & .030 & .061 & .197 & 82 & .053 & .068 & .191 \\
\hline $\mathrm{MktBk}_{t-1}$ & 193 & 4.264 & 1.874 & 6.966 & 82 & 2.443 & 1.636 & 2.404 \\
\hline Risk $_{t-x}$ & 174 & .068 & .020 & .143 & 71 & .049 & .019 & .105 \\
\hline Complex $^{\text {sub }} t-1$ & 193 & 1.987 & 2.708 & 3.460 & 82 & 1.40 & 2.350 & 3.638 \\
\hline Complex $_{t-1}^{\text {subfor }}$ & 193 & -.562 & 1.609 & 4.864 & 82 & -2.946 & 0 & 5.245 \\
\hline CurrPerf $^{\mathrm{SR}}$ & 193 & .143 & .031 & .560 & 82 & .193 & .079 & .480 \\
\hline CurrPerf $^{\mathrm{ROA}}$, & 193 & .071 & .080 & .098 & 82 & .081 & .070 & .068 \\
\hline 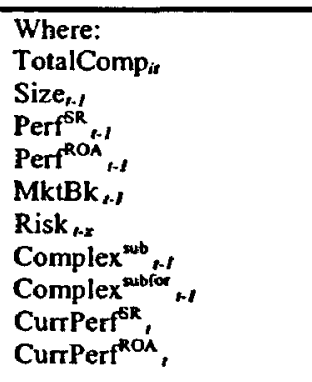 & $\begin{array}{l}\text { Log } \\
\text { Log } \\
\text { Prior } \\
\text { Prior } \\
\text { Mark } \\
\text { Stand } \\
\text { Log C } \\
\text { Log } \\
\text { Curre } \\
\text { Curre }\end{array}$ & $\begin{array}{l}\text { total compen } \\
\text { the market } v \\
\text { ar share retu } \\
\text { ar Retum on } \\
\text {-to-book rati } \\
\text { d deviation } \\
\text { number of su } \\
\text { number of fo } \\
\text { year share } r \\
\text { year ROA }\end{array}$ & $\begin{array}{l}\text { tion } \\
\text { le of equity } \\
\text { ssets (ROA) } \\
\text { ROA over pr } \\
\text { idiaries } \\
\text { ign subsidiar } \\
\text { in }\end{array}$ & years & & & & \\
\hline
\end{tabular}

The descriptive results for the manufacturing industry as explanation for the higher compensation offered by the equity firms compared to the cash firms appear more in line with the theory on levels of compensation, as the equity manufacturing firms are larger, have better prior share return performance, have more growth options, have more 
risk and are more complex. However, the cash firms seem to have better current performance.

Table 2.B.3c provides the descriptive results for the banking and finance industry:

Table 2.B.3c - Descriptive results for the independent variables for the Banking \& Finance ind ustry by compensation group:

\begin{tabular}{|l|c|c|c|c|c|c|c|c|}
\hline & \multicolumn{4}{|c|}{ Equity } & \multicolumn{4}{|c|}{ Cash } \\
\cline { 2 - 9 } & $\mathbf{n}$ & Mean & Median & $\begin{array}{c}\text { Std } \\
\text { dev }\end{array}$ & $\mathbf{n}$ & Mean & Median & $\begin{array}{c}\text { Std } \\
\text { dev }\end{array}$ \\
\hline TotalComp $_{i t}$ & 45 & 14.022 & 13.953 & .969 & 29 & 12.173 & 12.429 & .933 \\
\hline Size $_{t-1}$ & 45 & 21.051 & 21.269 & 2.383 & 29 & 19.314 & 19.325 & 1.264 \\
\hline Perf $_{t-l}{ }_{t}$ & 45 & .767 & .184 & 2.274 & 29 & .174 & .020 & .768 \\
\hline Perf $^{\text {ROA }}{ }_{t-1}$ & 45 & .019 & .011 & .071 & 29 & .066 & .042 & .098 \\
\hline MktBk $_{t-1}$ & 45 & 2.324 & 1.934 & 2.192 & 29 & 2.866 & 1.256 & 3.792 \\
\hline Risk $_{t-x}$ & 37 & .048 & .019 & .063 & 28 & .0681 & .045 & .085 \\
\hline Complex $^{\text {sub }}{ }_{t-1}$ & 45 & 3.321 & 3.714 & 2.361 & 29 & -.128 & 1.946 & 4.824 \\
\hline Complex $^{\text {subfor }}{ }_{t-1}$ & 45 & -1.672 & 1.097 & 6.052 & 29 & -5.831 & -9.21 & 5.157 \\
\hline CurrPerf $^{\text {fR }}{ }_{t}$ & 45 & .223 & .154 & .456 & 29 & .203 & .108 & .515 \\
\hline CurrPerf $^{\text {ROA }}{ }_{t}$ & 45 & .030 & .010 & .076 & 29 & .055 & .040 & .051 \\
\hline
\end{tabular}

Where:

TotalComp

Size

Perf ${ }^{\text {R }}$-1

Perf ${ }^{\text {Ron }}$

MktBk ${ }_{1-s}$

Risk $_{\text {r.x }}$

Complex

Complex subfor in

CurrPerf ${ }^{\mathrm{R}}$,

Log of total compensation

Log of the market value of equity

Prior year share retum

Prior year Return on Assets (ROA)

Market-10-book ratio

Standard deviation of ROA over prior 3 years

Log of number of subsidiaries

Log of number of foreign subsidiaries

Current year share return

CurPerf ${ }^{\text {ROA }}$,

Current year ROA

The largest difference in average compensation is observed in the banking and finance industry. The descriptive results for this industry show that the equity firms are larger, have better prior and current share return performance, and are more complex; but the equity firms also have fewer growth options, which is contra to expectations, and again, 
this result could simply indicate that our proxy of the market-to-book ratio does not describe well the growth options in the banking and finance industry.

Table 2.B.3d provides the descriptive results for the other industry:

Table 2.B.3d - Descriptive results for the independent variables for the Other industry by compensation group:

\begin{tabular}{|c|c|c|c|c|c|c|c|c|}
\hline & \multicolumn{4}{|c|}{ Equity } & \multicolumn{4}{|c|}{ Cash } \\
\hline & $\mathrm{n}$ & Mean & Median & $\begin{array}{l}\text { Std } \\
\text { dev }\end{array}$ & $\mathbf{n}$ & Mean & Median & $\begin{array}{l}\text { Std } \\
\text { dev }\end{array}$ \\
\hline TotalComp $_{i t}$ & 120 & 13.726 & 13.563 & .834 & 79 & 13.022 & 12.966 & .919 \\
\hline Size $_{t-1}$ & 120 & 19.686 & 19.479 & 1.825 & 79 & 18.990 & 18.658 & 1.216 \\
\hline $\operatorname{Perf}^{\mathrm{SR}}{ }_{t-1}$ & 120 & .553 & .103 & 1.867 & 79 & .094 & -.032 & .544 \\
\hline $\operatorname{Perf}^{\mathrm{ROA}}{ }_{t-1}$ & 120 & .024 & .070 & .244 & 79 & .081 & .075 & .072 \\
\hline MktBk $_{t-l}$ & 120 & 3.567 & 1.978 & 6.073 & 79 & 2.293 & 1.640 & 2.091 \\
\hline Risk $_{t-x}$ & 107 & .054 & .019 & .094 & 74 & .079 & .024 & .147 \\
\hline Complex ${ }^{\text {sub }}{ }_{t-I}$ & 120 & 2.740 & 2.803 & 2.238 & 79 & 2.626 & 2.640 & 1.803 \\
\hline Complex $^{\text {subfor }}{ }_{t-1}$ & 120 & -2.150 & .693 & 5.498 & 79 & -3.231 & 0 & 5.429 \\
\hline CurrPerf $^{\text {fR }}$, & 120 & .194 & .120 & .576 & 79 & .072 & .002 & .453 \\
\hline CurrPerf ${ }^{\mathrm{ROA}}{ }_{t}$ & 120 & .088 & .100 & .103 & 79 & .099 & .080 & .070 \\
\hline
\end{tabular}

Where:

TotalCompis Log of total compensation

Size $_{t-1} \quad$ Log of the market value of equity

Perf ${ }^{\text {SR }}$ Prior year share return

Perf ${ }^{\text {ROA }}$, Prior year Retum on Assets (ROA)

MktBk $\quad$ Market-to-book ratio

Risk f $_{\text {S }} \quad$ Standard deviation of ROA over prior 3 years

Complex ${ }^{\text {sub }}$ Log of number of subsidiaries

Complex ${ }^{\text {subfor }}$, Log of number of foreign subsidiaries

CurrPerf $f^{\mathrm{R}}$, Current year share retum

CurPerf $^{\text {ROA }}$, Current year ROA

The firms in the other industry appear similar to those in the manufacturing industry and appear to follow the traditional compensation level determinants. 
Univariate results:

Table 2.B.4 shows the correlations between total CEO compensation and the various firm characteristics: 
TABle 2.B.4 - CoRRELATIONS BeTWEen FIRM ChaRACTERISTICS AND TOTAL COMPENSATION:

\begin{tabular}{|c|c|c|c|c|c|c|c|c|c|}
\hline $\begin{array}{l}\text { Correlation between total } \\
\text { compensation }(\ln ) \& \text { : }\end{array}$ & $\operatorname{Size}_{t-l}$ & $\operatorname{Perf}^{6 R}{ }_{R-1}$ & Perf ${ }_{R-1}^{R O A}$ & $\mathrm{MktBk}_{1-l}$ & Risk $_{l-x}$ & Complex ${ }^{\text {sub }}{ }_{1.1}$ & $\begin{array}{c}\text { Complex } \\
\text { subfor } \\
-1\end{array}$ & CurrPerf $^{6 R}$, & CurrPerf ${ }^{\mathrm{ROA}}$, \\
\hline All companies & $.593 * *$ & .039 & $.152 * *$ & .061 & .042 & $.382^{* *}$ & $.383^{* *}$ & $.108^{* *}$ & $.164^{* *}$ \\
\hline \multicolumn{10}{|l|}{ By compensation group: } \\
\hline Equity & $.654^{* *}$ & .047 & $.271^{* *}$ & $-.101^{*}$ & .047 & $.338 * *$ & $.314^{* *}$ & $.113^{*}$ & $.203 * *$ \\
\hline$\overline{\text { Cash }}$ & $.406 * *$ &. .049 & .038 &. .123 & .051 & $.452^{* *}$ & $.406 * *$ & .113 & $.225^{* *}$ \\
\hline \multicolumn{10}{|l|}{ By Industry group: } \\
\hline Mining & $.585 * *$ & -.113 & $.416^{* *}$ & $-.223^{*}$ & -.028 & $.475^{* *}$ & $.412^{* *}$ & .153 & $.382^{* *}$ \\
\hline Manufacturing & $.637 * *$ & .049 & .111 & -.061 & .052 & $.255^{* *}$ & $.313^{* *}$ & .103 & $.160^{* *}$ \\
\hline Banking \& Finance & $.628^{* *}$ & -.038 & $-.360^{* *}$ & -.179 & .094 & $.647^{* *}$ & $.624^{* *}$ & .057 & $-.232^{*}$ \\
\hline Other & $.541^{* *}$ & .126 & .034 & .044 & .025 & $.180^{*}$ & $.349^{* *}$ & .102 & .051 \\
\hline \multicolumn{10}{|l|}{$\begin{array}{l}\text { By Industry \& } \\
\text { compensation group: }\end{array}$} \\
\hline Mining - equity & $.612^{* *}$ & -.003 & $.602^{* *}$ & $-.266^{*}$ & -.103 & $.598^{* *}$ & $.354^{* *}$ & $.253^{*}$ & $.517^{* *}$ \\
\hline Mining - cash & $.622 * *$ & -.189 & .186 & -.126 & .129 & .259 & $.465^{* *}$ & .027 & $.311^{*}$ \\
\hline Manufacturing - equity & $.589 * *$ & .046 & $.163^{*}$ & -.118 & .081 & $.172^{*}$ & $.285^{* *}$ & .104 & $.144^{*}$ \\
\hline Manufacturing - cash & $.677^{* *}$ & .049 & .048 & -.033 & -.107 & $.410^{* *}$ & $.247^{*}$ & .158 & $.319^{* *}$ \\
\hline $\begin{array}{l}\text { Banking \& finance - } \\
\text { equity }\end{array}$ & $.721^{* *}$ &. $.314^{*}$ & .094 & -.277 & $.327^{*}$ & $.369^{*}$ & $.617^{* *}$ & -.065 & -.110 \\
\hline Banking \& finance - cash & .052 & .219 & $-.444^{*}$ & -.066 & .193 & $.730^{* *}$ & $.495^{* *}$ & .241 & -.272 \\
\hline Other - equity & $.657^{* *}$ & .127 & .124 & .052 & .034 & .041 & $.284^{* *}$ & .006 & .094 \\
\hline Other - cash & $.251^{*}$ & -.103 & .022 & $-.225^{*}$ & .097 & $.435^{* *}$ & $.417^{* *}$ & .171 & .052 \\
\hline
\end{tabular}

** Correlation is significant at the 0.01 level (2-tailed). 


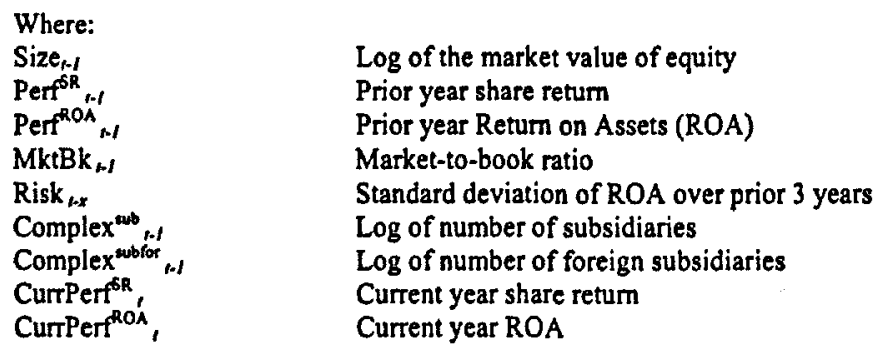


Taking the total sample, the firm characteristics significantly and positively correlated to the levels of total compensation are firm size, share returns and complexity. Interestingly, growth options are not significantly related. The correlation matrix also shows that the significantly related firm characteristics differ by industry and by compensation group.

The correlations also appear to differ across compensation group and industry. Looking at the two compensation groups, while firm size, complexity and current accounting performance are positively significant to both groups, prior accounting performance is only positively significant for the equity group, and the significance of the current market performance is reduced for both groups. By industry, while firm size and complexity are positively significant to all industries, the other characteristics differ across industry. Current accounting performance is positively significant to the mining and manufacturing industries, and weakly negatively for the banking and finance industry. Prior accounting performance has a positive association in the mining industry, and again is negative in banking and finance.

Table 2.B.4 also reports the correlations by industry and compensation group, and shows that the significance of correlation differs across both industry and compensation sub-groups. These results imply that firms in different industries and choosing different compensation contracts determine the level of compensation dependent on different firm characteristics. Consequently, the regression models in this appendix are estimated on 
the sub groups as well as the combined sample, in order to obtain a clearer understanding of the determinants of the levels of compensation.

Table 2.B.5 reports the correlations between the firm characteristics and the different components of compensation (base, salary, other, bonus and equity) by compensation group. For these tests, none of the compensation components are logged: 
TABLE 2.B.5 - CORRELATIONS BETWEen FIRM CHARACTERISTICS AND THE COMPONENTS OF TOTAL COMPENSATION:

\begin{tabular}{|c|c|c|c|c|c|c|c|c|c|}
\hline $\begin{array}{c}\text { Correlation between } \\
\text { total compensation }{ }^{14} \\
\& \text { : }\end{array}$ & Size $_{t-l}$ & $\operatorname{Perf}^{S R}{ }_{1-1}$ & $\operatorname{Perf}_{1-1}^{R O A}$ & $\mathrm{MktBk}_{t-l}$ & Risk $_{1-x}$ & Complex ${ }^{\text {sub }}{ }_{1-1}$ & Complex ${ }^{\text {subfor }}{ }_{1-1}$ & CurrPerf ${ }^{\delta R}$, & CurrPerf ${ }^{R O A}$, \\
\hline \multicolumn{10}{|l|}{ Cash: } \\
\hline Base & $.275^{* *}$ & -.060 & .049 & $-.136^{*}$ & .029 & $.296^{* *}$ & $.291^{* *}$ & .026 & $.159^{*}$ \\
\hline Other & $.371^{* *}$ & -.017 & .058 & .039 & .004 & $.153^{*}$ & $.196^{*}$ & $.145^{*}$ & $.158^{*}$ \\
\hline Bonus & $.264^{* *}$ & .0 & .035 & .011 & -.048 & .114 & $.160^{*}$ & $.200^{* *}$ & .089 \\
\hline \multicolumn{10}{|l|}{ Equity: } \\
\hline$\overline{\text { Base }}$ & $.736^{* *}$ & -.081 & $.192 * *$ & $-.141^{* *}$ & .031 & $.371^{* *}$ & $.361^{* *}$ & -.019 & $.178^{* *}$ \\
\hline Other & $.242^{* *}$ & -.038 & .045 & -.033 & $.103^{*}$ & $.143^{* *}$ & $.144 * *$ & -.037 & .067 \\
\hline Bonus & $.369^{* *}$ & -.027 & .080 & -.046 & -.022 & $.172^{* *}$ & $.165^{* *}$ & .066 & $.315^{* *}$ \\
\hline Equity & .081 & $.221^{* *}$ & -.055 & .049 & .006 & $-.112^{*}$ & -.018 & $.099^{*}$ & $-.108^{*}$ \\
\hline
\end{tabular}

** Correlation is significant at the 0.01 level (2-tailed).

"Correlation is significant at the 0.05 level (2-tailed)

Where:

Size $_{\text {-1 }}$
Perf

Perf $^{\text {Pon }}{ }^{t-1}$

$M k t B k_{t-1}$

Risk

Complex

Complex ${ }^{\text {utbor }}$ t.

CurrPerf ${ }^{\text {fR }}$

CurrPerf $^{20 A}$

Log of the market value of equity

Prior year share retum

Prior year Return on Assets (ROA)

Market-to-book ratio

Standard deviation of ROA over prior 3 years

Log of number of subsidiaries

Log of number of foreign subsidiaries

Current year share retum

Current year ROA

Base compensation in year $t$

$\begin{array}{ll}\text { Bonus } & \text { Bonus compensation in year } t+1 \\ \text { Other } & \text { Other compensation in year } t\end{array}$

$\begin{array}{ll}\text { Other } & \text { Other compensation in year } t \\ \text { Equity } & \text { Equity-based compensation granted in year } t\end{array}$

${ }^{14}$ For these tests none of the variables are logged 
Table 2.B.5 shows that size is still significant in determining the levels of the individual components of compensation, except for the equity-based compensation awarded to the equity group. Table 2.B.4 above shows that past share returns were weakly significant for total levels of compensation in the equity group, and Table 2.B.5 indicates that this relation is with the amount of equity-based compensation awarded. This could indicate that CEOs prefer more equity-based compensation when firms have performed well in the past, or that equity-based compensation is awarded to compensate for good past performance.

Mixed results for the ROA measure were reported in Table 2.B.4, but Table 2.B.5 reveals a strong positive correlation between ROA and base salary in the equity group. Growth options were not significant at all in Table 2.B.4, but are negatively significantly related to base salaries in both the equity and cash groups. Firm complexity appears positively important in setting levels of most components of pay for both compensation groups.

Finally, current firm performance appears important to more than just the bonus portion of total compensation. For the cash group, current market performance is strongly related to the level of the bonus awarded, while the level of accounting performance is not. This result is interesting, and could indicate that for those firms not providing the CEO with any equity-based compensation, the bonus scheme is in some way related to stock market performance. For these cash group firms, market performance is also 
related to other compensation, while accounting performance is related to base and other compensation.

Contrary to the results on current performance found in the cash group, the bonus portion of the equity group total compensation appears dependent on accounting performance, the more traditional expectation of bonus schemes. Similarly, the level of base compensation is also related to current accounting performance. Although the level of equity-based compensation awarded is strongly related to past market performance, it is only weakly related to current market performance, and negatively and weakly related to current accounting performance.

\section{Multivariate results:}

Table 2.B.6 provides the results for the regression analysis of levels of compensation on the economic characteristics of the firm: 
TABLE 2.B.6 - SUMMARY OF THE OLS REGRESSION COEFFICIENTS FOR THE RELATION BETWEEN TOTAL COMPENSATION AND UNDERLYING FIRM CHARACTERISTICS:

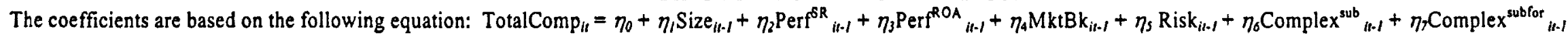
$+\eta_{8}$ CurrPerf $^{\text {fR }},+\eta_{9}$ CurrPerfof,$+\varepsilon_{1}$. The $t$ statistics are reported in brackets.

\begin{tabular}{|c|c|c|c|c|c|c|c|c|}
\hline \multirow[t]{2}{*}{ Variables: } & \multirow{2}{*}{$\begin{array}{l}\text { Predicted } \\
\text { sign }\end{array}$} & \multirow[t]{2}{*}{ Total sample } & \multicolumn{2}{|c|}{ Group } & \multicolumn{4}{|c|}{ Industry } \\
\hline & & & Cash & Equity & Mining & Manufacturing & Banking \& finance & Other \\
\hline & & $N=672$ & $N=231$ & $N=441$ & $N=124$ & $N=275$ & $N=74$ & $N=199$ \\
\hline Intercept & $+1-$ & $\begin{array}{c}7.187 \\
\left(17.977^{* * *}\right)\end{array}$ & $\begin{array}{l}7.829 \\
(9.989 * * *)\end{array}$ & $\begin{array}{c}6.696 \\
\left(15.890^{* * *}\right)\end{array}$ & $\begin{array}{c}7.413 \\
\left(7.914^{* * *}\right)\end{array}$ & $\begin{array}{l}5.279 \\
\left(8.088^{* * *}\right)\end{array}$ & $\begin{array}{c}7.634 \\
\left(6.073^{* * *}\right)\end{array}$ & $\begin{array}{c}7.903 \\
\left(10.541^{* * *}\right)\end{array}$ \\
\hline Size $_{1 \cdot 1}$ & + & $\begin{array}{c}0.308 \\
\left(14.861^{* * *}\right)\end{array}$ & $\begin{array}{c}0.265 \\
\left(6.280^{* * *}\right)\end{array}$ & $\begin{array}{c}0.342 \\
\left(15.865^{* * *}\right)\end{array}$ & $\begin{array}{c}0.295 \\
\left(5.916^{* * *}\right)\end{array}$ & $\begin{array}{c}0.413 \\
\left(11.949^{* * *}\right)\end{array}$ & $\begin{array}{c}0.283 \\
\left(4.810^{* * *}\right)\end{array}$ & $\begin{array}{c}0.295 \\
\left(7.602^{* * *}\right)\end{array}$ \\
\hline $\operatorname{Perf}^{S R}{ }_{1-1}$ & + & $\begin{array}{c}0.0043 \\
\left(1.674^{*}\right)\end{array}$ & $\begin{array}{c}0.063 \\
(1.012)\end{array}$ & $\begin{array}{c}0.036 \\
(1.437)\end{array}$ & $\begin{array}{c}0.083 \\
(0.988)\end{array}$ & $\begin{array}{c}0.019 \\
(0.384)\end{array}$ & $\begin{array}{l}-0.018 \\
(-0.250)\end{array}$ & $\begin{array}{c}0.053 \\
(1.250)\end{array}$ \\
\hline $\operatorname{Perf}_{1.1}^{R O A}$ & + & $\begin{array}{c}-0.246 \\
(-1.259) \\
\end{array}$ & $\begin{array}{l}-1.878 \\
\left(-4.377^{* * *}\right) \\
\end{array}$ & $\begin{array}{c}0.376 \\
\left(1.931^{*}\right)\end{array}$ & $\begin{array}{c}0.395 \\
(0.997) \\
\end{array}$ & $\begin{array}{c}-0.066 \\
(-0.245) \\
\end{array}$ & $\begin{array}{c}-3.437 \\
\left(-2.552^{* *}\right)\end{array}$ & $\begin{array}{c}-0.147 \\
(-0.352) \\
\end{array}$ \\
\hline $\mathrm{MktBk}_{t-1}$ & + & $\begin{array}{c}-0.0127 \\
\left(-1.865^{*}\right)\end{array}$ & $\begin{array}{l}-0.125 \\
\left(-4.935^{* * *}\right)\end{array}$ & $\begin{array}{c}-0.072 \\
(-1.155)\end{array}$ & $\begin{array}{c}-0.091 \\
\left(-2.534^{* *}\right)\end{array}$ & $\begin{array}{c}-0.012 \\
(-1.558)\end{array}$ & $\begin{array}{c}-0.047 \\
(-1.245)\end{array}$ & $\begin{array}{c}-0.012 \\
(-0.889)\end{array}$ \\
\hline Risk $_{t-x}$ & $+1-$ & $\begin{array}{c}0.278 \\
(1.003) \\
\end{array}$ & $\begin{array}{c}0.252 \\
(0.565) \\
\end{array}$ & $\begin{array}{c}0.234 \\
(0.769) \\
\end{array}$ & $\begin{array}{c}1.371 \\
(1.280) \\
\end{array}$ & $\begin{array}{c}0.240 \\
(0.728) \\
\end{array}$ & $\begin{array}{c}0.220 \\
(0.163) \\
\end{array}$ & $\begin{array}{c}0.256 \\
(0.520) \\
\end{array}$ \\
\hline Complex $_{\text {sub }}$-I & + & $\begin{array}{c}0.382 \\
(3.438 * * *)\end{array}$ & $\begin{array}{l}0.072 \\
\left(3.198^{* * *}\right)\end{array}$ & $\begin{array}{c}0.015 \\
(1.160)\end{array}$ & $\begin{array}{c}0.042 \\
\left(1.974^{*}\right)\end{array}$ & $\begin{array}{c}-0.017 \\
(-1.051)\end{array}$ & $\begin{array}{l}0.088 \\
\left(2.713^{* * *}\right)\end{array}$ & $\begin{array}{c}-0.025 \\
(-0.775)\end{array}$ \\
\hline CurrPerf $^{\mathrm{SR}}$ & & $\begin{array}{c}0.0571 \\
\left(4.387^{* * *}\right)\end{array}$ & $\begin{array}{c}0.031 \\
\left(2.115^{* *}\right)\end{array}$ & $\begin{array}{c}0.126 \\
\left(5.766^{* * *}\right)\end{array}$ & $\begin{array}{c}0.028 \\
\left(1.876^{*}\right)\end{array}$ & $\begin{array}{c}0.131 \\
\left(4.251^{* * *}\right)\end{array}$ & $\begin{array}{c}0.135 \\
\left(2.300^{* *}\right)\end{array}$ & $\begin{array}{c}0.176 \\
\left(2.383^{* *}\right) \\
\end{array}$ \\
\hline CurrPerf $^{R 0 A}$, & & $\begin{array}{c}0.792 \\
\left(1.916^{*}\right)\end{array}$ & $\begin{array}{c}4.066 \\
\left(5.106^{* * *}\right)\end{array}$ & $\begin{array}{c}-0.054 \\
(-0.013)\end{array}$ & $\begin{array}{c}0.856 \\
(0.960)\end{array}$ & $\begin{array}{c}0.603 \\
(1.097)\end{array}$ & $\begin{array}{c}-0.371 \\
(-0.212)\end{array}$ & $\begin{array}{c}-0.451 \\
(-0.469)\end{array}$ \\
\hline Adjusted $R^{2}$ & & 0.415 & 0.428 & 0.491 & 0.488 & 0.440 & 0.670 & 0.338 \\
\hline$F$ ratio & & $48.146^{* * *}$ & $18.320^{* * *}$ & $42.791^{* * *}$ & $12.415^{* * *}$ & $22.344 * * *$ & $15.418^{* * *}$ & $11.208^{* * *}$ \\
\hline
\end{tabular}

*** significant at the 0.01 level (2-tailed) ** significant at the 0.05 level (2-tailed) " significant at the 0.10 level (2-tailed)

Where:

Size

Perf ${ }^{101}$

Mert $^{\text {Mkt }}{ }_{t-1}$

Risk ${ }_{t \rightarrow x}$

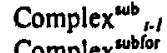

CurrPerfoí,

$\log$ of the market value of equity

Prior year share return

Prior year Retum on Assets (ROA)

Market-10-book ratio

Standard deviation of ROA over prior 3 years

Log of number of subsidiaries

Log of number of foreign subsidiaries

Current year share return

Current year ROA 
The regression model on the total sample shows that size, past share returns and complexity are positive and significant as determinants of the level of total compensation, while (contra to expectations) past ROA and growth options have a weak negative relation. The size and complexity results indicate that, consistent with theory, larger and more complex firms require higher quality CEOs and consequently pay higher wages to their CEOs. The positive result on share returns indicates that past performance is rewarded with higher future salaries, but this seems limited to only stock performance. The weak negative relation with growth options was not as expected, and implies that either the proxy is not adequate, or that the size and complexity proxies are adequate in explaining the demand for higher quality CEOs. Finally, current market performance is strongly positively related to total compensation, while current accounting performance has only a weak, but negative, relation.

The regression results are also provided in Table 2.B.6 for the sample split on both compensation group and industry. These results show that while firm size is always an important determinant of the level of compensation, the other determinants differ according to both group and industry.

For the cash and equity compensation groups, size is positively significant for both groups, while complexity is significant only for the cash group. Interestingly, growth options are significant and negative for the cash group, which is contra to expectations. Past share returns are not important determinants for either group, while past accounting performance is negative and strongly significant as a determinant in the cash group, 
while a weak positive relation is found for the equity group. This strong negative relation in the cash group is odd, as it would be expected that current salaries would include some reward for past performance. However, current market performance is significant for both groups (although more so for the equity group), implying that regardless of compensation contract structure, the level of CEO compensation has some relation to current market performance. However, current accounting performance only has a significant relation in the cash group. Overall, the models' adjusted $\mathrm{R}^{2}$ implies that the model fits slightly better on the equity group. Core, Holthausen and Larcker (1999) include a number of additional corporate governance variables in their models, but overall their adjusted $\mathrm{R}^{2}$ is $37.2 \%$, lower than that obtained in these regressions.

The industry level regressions in Table 2.B.6 indicate that as well as the determinants being different for the compensation groups, they are also different dependent on industry. First, the adjusted $\mathrm{R}^{2} \mathrm{~s}$ indicate that the variables best describe the level of compensation in the banking and finance industry, where the adjusted $R^{2}$ is $67 \%$, compared to $41.5 \%$ for the total sample. With regard to the individual variables, firm size remains positively significant for all industries. Also significant across all industries is current market performance, although this significance is weak in all but the manufacturing industry. Current accounting performance was not significant in any industry. Prior accounting performance was negative and weakly significant in the banking and finance industry, and insignificant in all others, while prior market performance was insignificant in all industries. The complexity results are mixed, with a weak association in the mining industry, no relation in the manufacturing industry and 
strong associations in the banking and finance and other industries. Growth options have a strong and negative relation in the mining industry and no relation in any other industry, and risk has no significance at the industry level. These results could indicate that industries set compensation differently, and / or that the proxies used represent the underlying economics differently in each industry. These industry results are interesting also as they differ from that found in the Core, Holthausen and Larcker (1999) study, as they state that their tests of industry give insignificant results ${ }^{15}$.

Using United States' data, Core, Holthausen and Larcker (1999) perform similar tests to those found on the total sample in this Appendix. Table 2.B.7 below show Core, Holthausen and Larcker (1999) results in comparison to these results:

is Core, Holthausen and Larcker (1999) include industry dummy variables in their regression to control for industry, and state that they find no result on industry. However, they do not report these results. 
TABle 2.B.7 - Comparison Between the Results in this APPEndiX to United States' results found IN CoRe,

HOLTHAUSEN AND LARCKER (1999) (CHL)

\begin{tabular}{|c|c|c|c|c|c|c|c|c|}
\hline \multirow[t]{2}{*}{ Variable } & \multirow[t]{2}{*}{ CHL RESULTS } & \multicolumn{7}{|c|}{ APPENDIX 2.B RESULTS (TABLE 2.B.6) } \\
\hline & & $\begin{array}{c}\text { FULL } \\
\text { SAMPLE } \\
N=672\end{array}$ & $\begin{array}{c}\text { CASH } \\
\text { GROUP } \\
\mathrm{N}=231\end{array}$ & $\begin{array}{l}\text { EQUITY } \\
\text { GROUP } \\
N=441\end{array}$ & $\begin{array}{c}\text { MINING } \\
\text { INDUSTRY } \\
N=124\end{array}$ & $\begin{array}{c}\text { MANUFACTURING } \\
\text { INDUSTRY } \\
\mathrm{N}=\mathbf{2 7 5}\end{array}$ & $\begin{array}{c}\text { BANKING } \\
\& \\
\text { FINANCE } \\
\text { INDUSTRY } \\
\mathrm{N}=74\end{array}$ & $\begin{array}{c}\text { OTHER } \\
\text { INDUSTRY } \\
\mathrm{N}=199\end{array}$ \\
\hline Size $_{t-1}$ & $\begin{array}{l}\text { Positive, } \\
\text { significant }\end{array}$ & $\begin{array}{l}\text { Positive, } \\
\text { significant }\end{array}$ & $\begin{array}{l}\text { Positive, } \\
\text { significant }\end{array}$ & $\begin{array}{l}\text { Positive, } \\
\text { significant }\end{array}$ & $\begin{array}{l}\text { Positive, } \\
\text { significant }\end{array}$ & Positive, significant & $\begin{array}{l}\text { Positive, } \\
\text { significant }\end{array}$ & $\begin{array}{l}\text { Positive, } \\
\text { significant }\end{array}$ \\
\hline $\operatorname{Perf}_{\text {R-1 }}^{\text {SR }}$ & $\begin{array}{l}\text { Positive, } \\
\text { significant }\end{array}$ & $\begin{array}{c}\text { Positive, } \\
\text { weak } \\
\text { significance }\end{array}$ & No result & No result & No result & No result & No result & No result \\
\hline $\operatorname{Perf}^{R O A}{ }_{t-1}$ & No result & No result & $\begin{array}{l}\text { Negative, } \\
\text { significant }\end{array}$ & $\begin{array}{c}\text { Positive, } \\
\text { weak } \\
\text { significance }\end{array}$ & No result & No result & $\begin{array}{c}\text { Negative, } \\
\text { weak } \\
\text { significance } \\
\end{array}$ & No result \\
\hline$\overline{\mathrm{MktBk}_{t-1}}$ & $\begin{array}{l}\text { Positive, } \\
\text { significant }\end{array}$ & $\begin{array}{c}\text { Negative, } \\
\text { weak } \\
\text { significance }\end{array}$ & $\begin{array}{l}\text { Negative, } \\
\text { significant }\end{array}$ & No result & $\begin{array}{c}\text { Negative, } \\
\text { weak } \\
\text { significance }\end{array}$ & No result & No result & No result \\
\hline Risk $_{t-x}$ & $\begin{array}{c}\text { Negative, } \\
\text { significant }\end{array}$ & No result & No result & No result & No result & No result & No result & No result \\
\hline Complex $^{\text {sub }}{ }_{t-1}$ & Not tested & $\begin{array}{c}\text { Positive, } \\
\text { significant }\end{array}$ & $\begin{array}{l}\text { Positive, } \\
\text { significant }\end{array}$ & No result & $\begin{array}{c}\text { Positive, } \\
\text { weak } \\
\text { significance }\end{array}$ & No result & $\begin{array}{c}\text { Positive, } \\
\text { significant }\end{array}$ & No result \\
\hline $\begin{array}{c}\text { Complex } \\
\text { subfor }\end{array}$ & Not tested & $\begin{array}{c}\text { Positive, } \\
\text { significant }\end{array}$ & $\begin{array}{l}\text { Positive, } \\
\text { significant }\end{array}$ & No result & No result & No result & $\begin{array}{c}\text { Positive, } \\
\text { weak } \\
\text { significance }\end{array}$ & $\begin{array}{l}\text { Positive, } \\
\text { significant }\end{array}$ \\
\hline CurrPerf $_{t}$ & Not tested & $\begin{array}{c}\text { Positive, } \\
\text { significant }\end{array}$ & $\begin{array}{c}\text { Positive, } \\
\text { weak } \\
\text { significance }\end{array}$ & $\begin{array}{c}\text { Positive, } \\
\text { significant }\end{array}$ & $\begin{array}{c}\text { Positive, } \\
\text { weak } \\
\text { significance }\end{array}$ & Positive, significant & $\begin{array}{c}\text { Positive, } \\
\text { weak } \\
\text { significance }\end{array}$ & $\begin{array}{c}\text { Positive, } \\
\text { weak } \\
\text { significance } \\
\end{array}$ \\
\hline CurrPerf $^{\mathrm{ROA}}$ & Not tested & $\begin{array}{c}\text { Positive, } \\
\text { weak } \\
\text { significance }\end{array}$ & $\begin{array}{l}\text { Positive, } \\
\text { significant }\end{array}$ & No result & No result & No result & No result & No result \\
\hline
\end{tabular}


Core, Holthausen and Larcker (1999) use total sales to proxy for both firm size and complexity and find significant positive relations with total compensation. This Appendix uses different measures for complexity and size and finds that both size and complexity have a positive significant relation to total compensation, although complexity is not as important in the mining industry. Core, Holthausen and Larcker (1999) find a strong positive relation on the prior market returns measure, which is not observed in this sample. They find no result for the prior performance (ROA) measure, and while this Appendix finds similar results in the total sample, a strong negative relation is seen in the cash group and in the banking and finance industry, while a weak positive result is seen in the equity group. This Appendix also finds opposite results on the growth options variable, and although the significance is weak in the total sample, it is stronger in the cash group and to a lesser extent in the mining industry. Finally, while Core, Holthausen and Larcker (1999) find a negative association between risk and compensation, this Appendix finds no relation.

These results suggest that as well as having different compensation structures from the United States, Australian levels of compensation could also be determined on a different basis to those in the United States, especially in relation to the proxies for growth options and risk. However, one possible explanation is the differences in the proxies used to measure firm size between this study and the Core et al study, and this possible explanation is examined further. In order to determine whether it is the proxies used in this Appendix that are driving the different results, the regression is re-estimated using 
sales as a proxy for both firm size and complexity, and re-estimated using sales as only firm size and including the subsidiaries measures as proxies for firm complexity. The results from these two regressions are reported in Table 2.B.8:

TABLE 2.B.8 - SUMMARY OF TIE OLS REGRESSION COEFFICIENTS FOR THE RELATION BETWEEN TOTAL COMPENSATION AND UNDERLYING FIRM CHARACTERISTICS USING

THE CORE, HolTHAUSEN ANd LARCKER (1999) PROXIES FOR FIRM SIZE:

The coefficients are based on the following equation: Total Compensation ${ }_{i f}=\eta_{0}+\eta_{1}$ Size $_{i t-1}+\eta_{2}$ Perf $^{5 R}{ }_{i t-1}+$

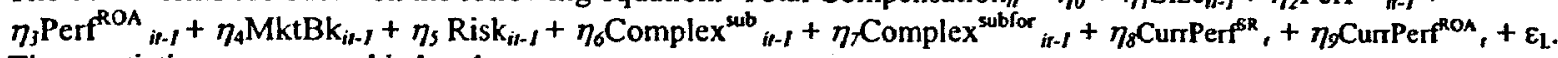
The $t$ statistics are reported in brackets.

\begin{tabular}{|c|c|c|c|}
\hline Variables: & $\begin{array}{l}\text { Predicted } \\
\text { sign }\end{array}$ & & \\
\hline & & $N=672$ & $N=672$ \\
\hline Intercept & $+/-$ & $\begin{array}{c}10.213 \\
\left(45.864^{* * *}\right)\end{array}$ & $\begin{array}{c}10.836 \\
\left(44.949^{* * *}\right)\end{array}$ \\
\hline Size $_{t-1}$ (In Sales) & + & $\begin{array}{c}0.157 \\
\left(13.593^{* * *}\right)\end{array}$ & $\begin{array}{l}0.123 \\
\left(9.580^{* * *}\right)\end{array}$ \\
\hline $\operatorname{Perf}^{6 \mathrm{R}}$ & + & $\begin{array}{c}0.068 \\
\left(2.352^{* *}\right)\end{array}$ & $\begin{array}{l}0.078 \\
\left(2.790^{* * *}\right)\end{array}$ \\
\hline $\operatorname{Perf}_{A-1}^{R O A}$ & + & $\begin{array}{c}0.027 \\
(0.145)\end{array}$ & $\begin{array}{c}-0.133 \\
(-0.623)\end{array}$ \\
\hline $\mathrm{MktBk}_{\text {-1 }}$ & + & $\begin{array}{c}0.037 \\
(0.487) \\
\end{array}$ & $\begin{array}{c}0.063 \\
(0.843) \\
\end{array}$ \\
\hline Risk $_{t-x}$ & $+1-$ & $\begin{array}{c}0.357 \\
(1.140) \\
\end{array}$ & $\begin{array}{c}0.318 \\
(1.051) \\
\end{array}$ \\
\hline Complex $_{t-I}^{\text {sub }}$ & + & & $\begin{array}{c}0.037 \\
\left(3.020^{* * *}\right)\end{array}$ \\
\hline Complex $^{\text {subfor }}{ }_{t-1}$ & + & & $\begin{array}{l}0.031 \\
\left(4.054^{* * *}\right)\end{array}$ \\
\hline CurrPerf $^{\mathrm{SR}}$, & & & $\begin{array}{l}0.034 \\
\left(2.439^{* *}\right)\end{array}$ \\
\hline CurrPerf $^{\mathrm{ROA}}$ & & & $\begin{array}{l}0.065 \\
0.138 \\
\end{array}$ \\
\hline Adjusted $R^{2}$ & & 0.250 & 0.304 \\
\hline$F$ ratio & & $41.97^{* * *}$ & $30.046^{* * *}$ \\
\hline
\end{tabular}

$* * *$ significant at the 0.01 level (2-tailed). ** significant at the 0.05 level (2-tailed) * significant at the 0.10 level (2-tailed) Where:

Size $_{1-1}$

Perfer $f_{t-1}$

Perf ${ }^{\mathrm{ROA}} \mathrm{A}_{k-1}$

$\mathrm{MktBk}_{t-1}$

Risk $_{t-x}$

Complex ${ }^{\text {sub }}$ Complex

CurrPerf

CurrPerfó,

Log of total sales

Prior year share retum

Prior year Return on Assets (ROA)

Market-to-book ratio

Standard deviation of ROA over prior 3 years

Log of number of subsidiaries

Log of number of foreign subsidiaries

Current year share return

Current year ROA

Table 2.B.8 provides similar results to those found for the total sample in Table 2.B.6.

There are some important differences. First, the adjusted $R^{2}$ is much better in Table 
2.B.6 $(41.5 \%)$ compared to that above (30.4\%), which suggests that the log of the market value of equity provides a better proxy for the element of firm size that drives levels of total compensation compared to the log of total sales. The significance of some of the variables has also changed in Table 2.B.8 - prior market performance has increased in significance, while current market performance has reduced significance. Growth options are no longer significant at all, nor is the current accounting performance. The results are still different from those obtained by Core, Holthausen and Larcker (1999), and thus further indicate that Australian firms set levels of compensation somewhat differently to firms in the United States, which further suggests that studying CEO compensation in Australia provides new opportunities for research.

One possible explanation is that the characteristics of the Australian firms in this appendix appear quite different from those in the Core, Holthausen and Larcker (1999) study. While both studies use large firms in the relative markets, unsurprisingly on comparing the mean sales in each study, this appendix's firms are much smaller (mean sales aud $\$ 1,141$ million (1999 to 2001) compared to usd $\$ 6,523$ million (1984) in Core, Holthausen and Larcker (1999)). Comparing the growth option proxy, Core, Holthausen and Larcker's (1999) firms have a mean (median) of 1.365 (1.170) compared to 3.148 (1.762) in this appendix. The higher level of growth options in this appendix is surprising given Australia's relatively liberal accounting regime compared to the United States, but this could be a result of the size of the firms included in the appendix, especially if the large Australian firms adopt conservative accounting practices. Overall, these results indicate that unlike the United States, firms in Australia do not 
increase the level of total compensation for greater growth options, nor decrease compensation for greater risk ${ }^{16}$.

Finally, Table 2.B.9 reports the results by industry and by compensation group:

${ }^{16}$ Chapter Two also shows that firms in Australian offer less equity-based compensation compared to their United States counterparts. These results in Appendix $\mathrm{C}$ may indicate some possible explanations for these findings, and are explored further in Chapter Three. 
TABLE 2.B.9 - SUMMARY OF THE OLS REGRESSION COEFFICIENTS FOR THE RELATION BETWEEN TOTAL COMPENSATION AND UNDERLYING FIRM CHARACTERISTICS BY INDUSTRY AND COMPENSATION GROUP:

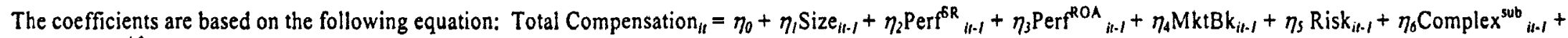

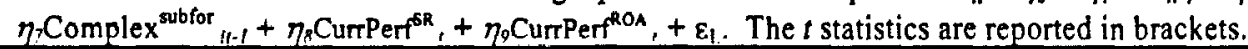

\begin{tabular}{|c|c|c|c|c|c|c|c|c|c|}
\hline \multirow[t]{2}{*}{ Variables: } & \multirow{2}{*}{$\begin{array}{l}\text { Predict } \\
\text { ed sign }\end{array}$} & \multicolumn{2}{|c|}{ Mining } & \multicolumn{2}{|c|}{ Manufacturing } & \multicolumn{2}{|c|}{ Banking \& Finance } & \multicolumn{2}{|c|}{ Other } \\
\hline & & Cash & Equity & Cash & Equity & Cash & Equity & Cash & Equity \\
\hline & & $N=41$ & $N=83$ & $N=82$ & $N=193$ & $N=29$ & $N=45$ & $N=79$ & $N=120$ \\
\hline Size $_{1-1}$ & + & $\begin{array}{c}0.489 \\
(6.089 * * *) \\
\end{array}$ & $\begin{array}{c}0.256 \\
(4.628 * * *)\end{array}$ & $\begin{array}{l}0.463 \\
\left(7.468^{* * *}\right) \\
\end{array}$ & $\begin{array}{c}0.407 \\
\left(10.315^{* * *}\right)\end{array}$ & $\begin{array}{c}-0.266 \\
(-1.669) \\
\end{array}$ & $\begin{array}{c}0.278 \\
(4.779 * * *) \\
\end{array}$ & $\begin{array}{c}0.186 \\
\left(2.106^{* *}\right) \\
\end{array}$ & $\begin{array}{c}0.342 \\
\left(9.417^{* * *}\right) \\
\end{array}$ \\
\hline $\operatorname{Perf}_{t-1}$ & + & $\begin{array}{c}0.020 \\
(0.164) \\
\end{array}$ & $\begin{array}{l}0.060 \\
(0.551) \\
\end{array}$ & $\begin{array}{c}0.031 \\
(0.388) \\
\end{array}$ & $\begin{array}{c}0.054 \\
(1.206) \\
\end{array}$ & $\begin{array}{c}0.202 \\
(0.752) \\
\end{array}$ & $\begin{array}{c}-0.089 \\
(-1.449) \\
\end{array}$ & $\begin{array}{c}-0.053 \\
(-0.267) \\
\end{array}$ & $\begin{array}{c}0.032 \\
(0.950) \\
\end{array}$ \\
\hline $\operatorname{Perf}_{1-1}$ & + & $\begin{array}{c}-1.620 \\
(-1.456) \\
\end{array}$ & $\begin{array}{c}0.893 \\
\left(2.343^{* *}\right)\end{array}$ & $\begin{array}{l}-1.903 \\
\left(-4.405^{* * *}\right)\end{array}$ & $\begin{array}{c}0.331 \\
(1.048) \\
\end{array}$ & $\begin{array}{c}-1.255 \\
(-0.848) \\
\end{array}$ & $\begin{array}{c}-1.759 \\
(-0.958) \\
\end{array}$ & $\begin{array}{c}0.190 \\
(0.107) \\
\end{array}$ & $\begin{array}{c}0.384 \\
(1.098) \\
\end{array}$ \\
\hline $\mathrm{MktBk}_{1-1}$ & + & $\begin{array}{l}-0.177 \\
\left(-2.567^{* *}\right)\end{array}$ & $\begin{array}{c}-0.024 \\
(-0.658) \\
\end{array}$ & $\begin{array}{c}-0.164 \\
\left(-3.939^{* * *}\right) \\
\end{array}$ & $\begin{array}{r}-0.094 \\
(-1.196) \\
\end{array}$ & $\begin{array}{l}-0.028 \\
(0.522) \\
\end{array}$ & $\begin{array}{c}0.021 \\
(0.337) \\
\end{array}$ & $\begin{array}{c}-0.178 \\
\left(-3.166^{* * *}\right)\end{array}$ & $\begin{array}{c}-0.100 \\
(-0.930)\end{array}$ \\
\hline Risk $_{t-x}$ & $+1-$ & $\begin{array}{c}2.213 \\
(1.149) \\
\end{array}$ & $\begin{array}{c}1.235 \\
(1.020) \\
\end{array}$ & $\begin{array}{c}-0.667 \\
(-1.069) \\
\end{array}$ & $\begin{array}{c}0.398 \\
(1.123) \\
\end{array}$ & $\begin{array}{c}0.642 \\
(0.399) \\
\end{array}$ & $\begin{array}{c}2.671 \\
(1.584) \\
\end{array}$ & $\begin{array}{c}0.752 \\
(1.170) \\
\end{array}$ & $\begin{array}{c}-0.530 \\
(-0.825)\end{array}$ \\
\hline Complex ${ }_{\text {I-I }}^{\text {sub }}$ & + & $\begin{array}{c}-0.038 \\
(-0.876) \\
\end{array}$ & $\begin{array}{c}0.081 \\
\left(3.441^{* * *}\right) \\
\end{array}$ & $\begin{array}{r}0.036 \\
(1.584) \\
\end{array}$ & $\begin{array}{l}-0.042 \\
\left(-2.086^{* *}\right) \\
\end{array}$ & $\begin{array}{c}0.104 \\
\left(2.484^{* *}\right) \\
\end{array}$ & $\begin{array}{r}0.035 \\
(0.685) \\
\end{array}$ & $\begin{array}{r}0.080 \\
(1.308) \\
\end{array}$ & $\begin{array}{c}-0.097 \\
\left(-3.183^{* * *}\right)\end{array}$ \\
\hline CurrPerf $^{\mathrm{g} R}$, & & $\begin{array}{c}0.027 \\
(1.694) \\
\end{array}$ & $\begin{array}{c}0.040 \\
(0.978) \\
\end{array}$ & $\begin{array}{c}-0.012 \\
(-0.358)\end{array}$ & $\begin{array}{l}0.182 \\
\left(5.075^{* * *}\right)\end{array}$ & $\begin{array}{c}0.141 \\
(0.628) \\
\end{array}$ & $\begin{array}{c}0.100 \\
\left(1.965^{*}\right)\end{array}$ & $\begin{array}{c}0.131 \\
(0.629) \\
\end{array}$ & $\begin{array}{c}0.188 \\
\left(2.955^{* * *}\right) \\
\end{array}$ \\
\hline CurrPerf ${ }^{\text {ROA }}$ & & $\begin{array}{c}0.840 \\
(0.513) \\
\end{array}$ & $\begin{array}{c}0.491 \\
(0.494) \\
\end{array}$ & $\begin{array}{l}4.303 \\
\left(3.628^{* * *}\right) \\
\end{array}$ & $\begin{array}{c}0.011 \\
(0.020) \\
\end{array}$ & $\begin{array}{c}-3.349 \\
(-1.045) \\
\end{array}$ & $\begin{array}{c}0.818 \\
(0.457) \\
\end{array}$ & $\begin{array}{c}4.331 \\
\left(1.947^{*}\right)\end{array}$ & $\begin{array}{c}-1.482 \\
\left(-1.660^{*}\right) \\
\end{array}$ \\
\hline Adjusted $R^{2}$ & & 0.602 & 0.603 & 0.631 & 0.441 & 0.560 & 0.667 & 0.314 & 0.511 \\
\hline$F$ ratio & & $6.891^{* * *}$ & $13.158^{* * *}$ & $14.310^{* * *}$ & $16.178^{* * *}$ & $4.825^{* * *}$ & $9.000^{* * *}$ & $4.721 * * *$ & $13.299 * * *$ \\
\hline
\end{tabular}

*** significant at the 0.01 level (2-tailed) ** significant at the 0.05 level (2-tailed) * significant at the 0.10 level (2-tailed)

Where:

Size,.1

Perf ${ }^{6 R}$ Pent

Perfork,

Risk

Complex ${ }^{\text {sub }}$ (1)

Complex

Log of the market value of equity

Prior year share return

Prior year Return on Assets (ROA)

Market-to-book ratio

Standard deviation of ROA over prior 3 years

Log of number of subsidiaries

Log of number of foreign subsidiaries

Current year share reum

Current year ROA 
Overall, the regressions show that the power of the explanatory variables is different by both industry and group. All of these results should be interpreted with caution, as the smaller sample sizes in all groups made winsorising of outliers difficult, and deletion of outliers would have made even smaller samples. Consequently, only the most extreme outliers were winsorised, and the regressions run with the other outliers still in place.

The very small sample sizes in the banking and finance industry make interpretation of these regressions difficult. The F statistic for the equity group is only significant at the $5 \%$ level, and none of the explanatory variables have any power. While the cash regression has a more significant $F$ statistic, the significance of the variables is low. Given the small sample sizes, these results are suggestive only.

The results from the other industries have more power, and indicate the variance across the different industries and groups in the way that total CEO compensation relates to firm characteristics. Firm size is constantly important, although not as significant in the other cash group. The share return result previously observed appears confined to only the equity manufacturing group. ROA has some weak significance to the other cash group, while the negative growth options result is confined to the mining cash group, and with less power to the other cash group. The complexity variable has both negative and positive implications across the different groups and industries.

Overall, these results indicate that the proxies represent the underlying economics differently in each industry, as well as showing that compensation is set differently in 
each compensation group. However, care must be taken in the interpretation of these results due to the small sample sizes and difficulty in adjusting for all outliers.

\section{Summary and Conclusion}

This Appendix provides the results on the link between the levels of compensation and firm characteristics and finds that in general, the level of CEO compensation in the total sample is significantly positively related to firm size, complexity and current market performance, and more weakly positively related to growth options, prior market performance and current accounting performance. This Appendix also shows that with the exception of firm size, the significance of the other firm characteristics differs across both the compensation and industry groups. The comparison of these results with those found in the United States by Core, Holthausen and Larcker (1999) suggest that there is some similarity between Australia and the United States in the way in which the level of CEO compensation is decided. Overall, the results in this Appendix suggest that the levels of CEO compensation in Australia are based on the underlying economic characteristics of the firm. 


\section{APPENDIX 2.C: \\ OPTION GRANT CHARACTERISTICS ACROSS INDUSTRY GROUPS}

Chapter Two provides evidence of the option grant characteristics across the whole sample. This appendix provides evidence on the option grants across the industry groups.

Graphs 2.C.1 through 2.C.3 detail the option grant characteristics across the different industry groups: 
GraPh 2.C.1 - EXERCISE PriCES ACROSS INDUSTRY: ${ }^{17}$
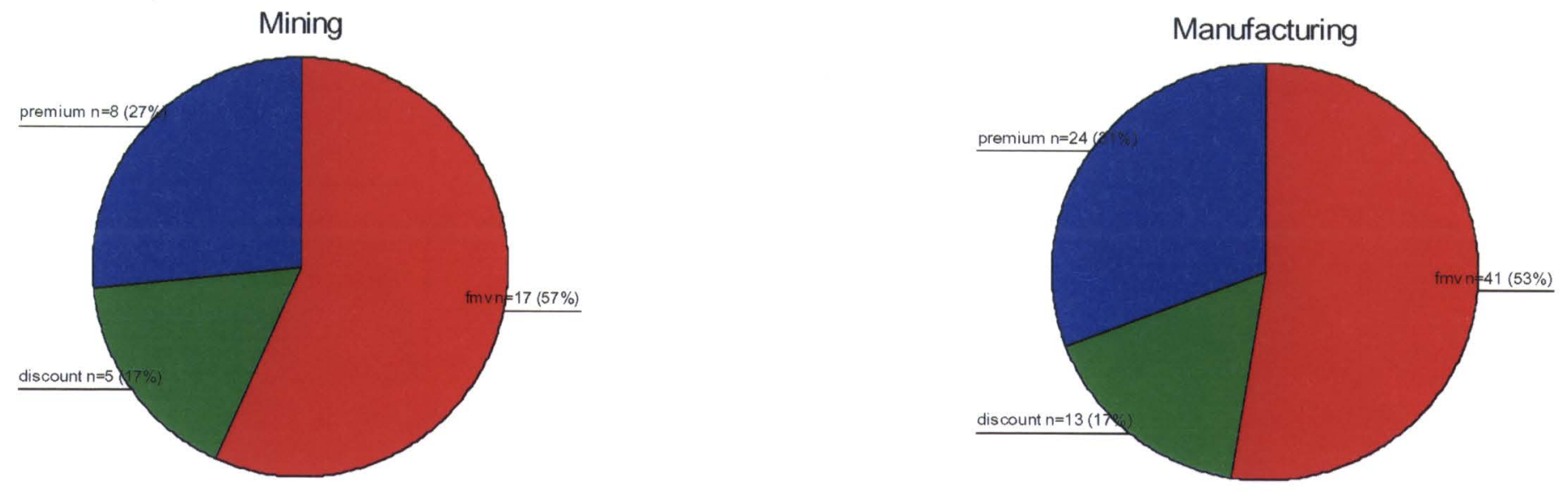

Banking \& Finance
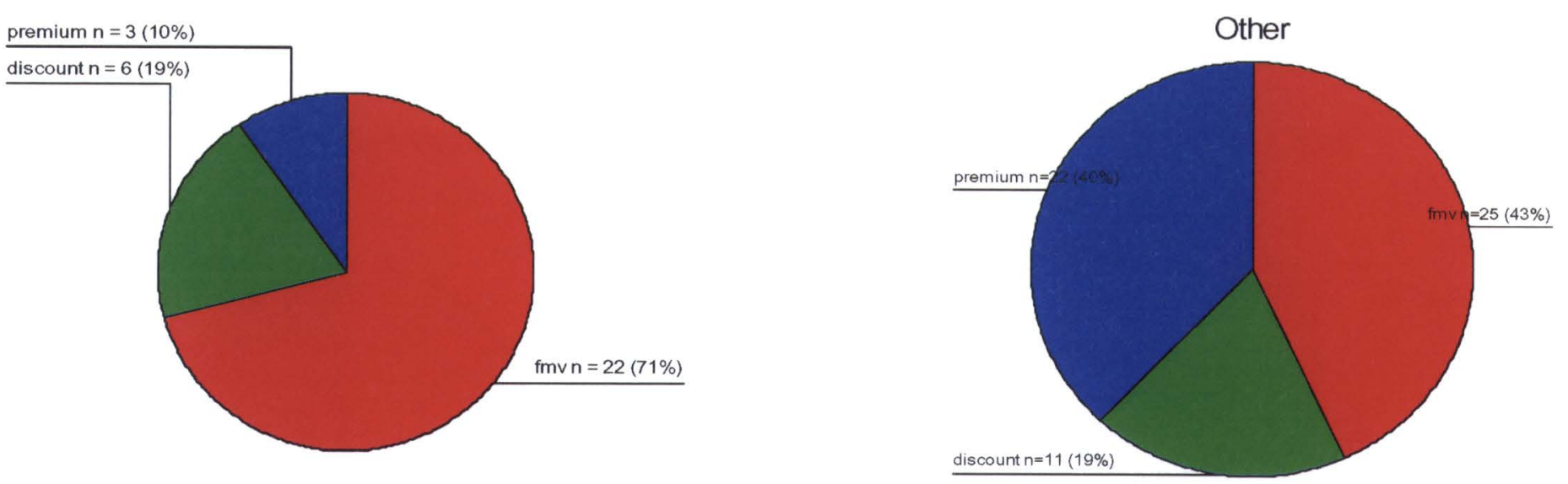

${ }^{17}$ Where: $\mathrm{FMV}=$ fair market value options - exercise price $=$ stock price on the day of issue of the options; premium = exercise price $>$ stock price on day of issue; and discount $=$ exercise price $<$ stock price on day of issue. 
GRAPH 2.C.2 - OPTION TERMS ACROSS INDUSTRY:

\section{Mining}

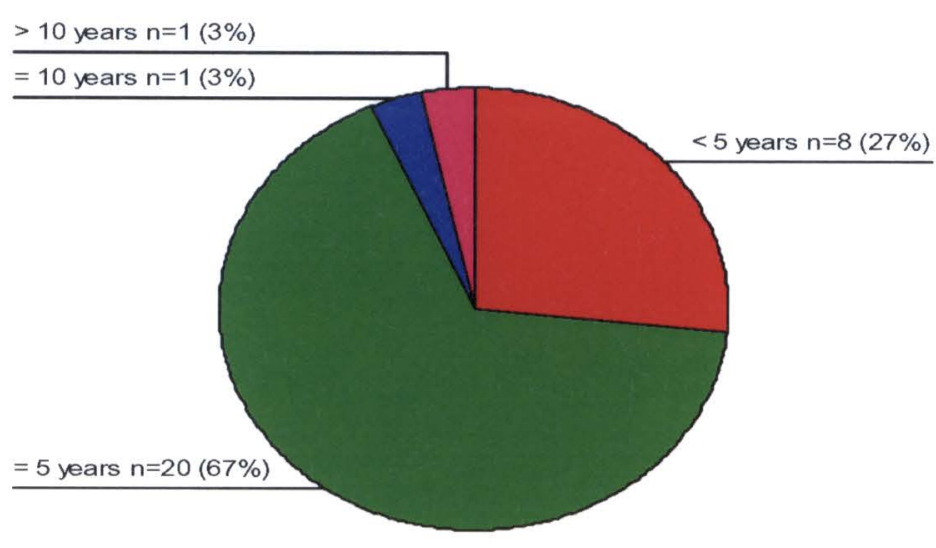

Banking \& Finance

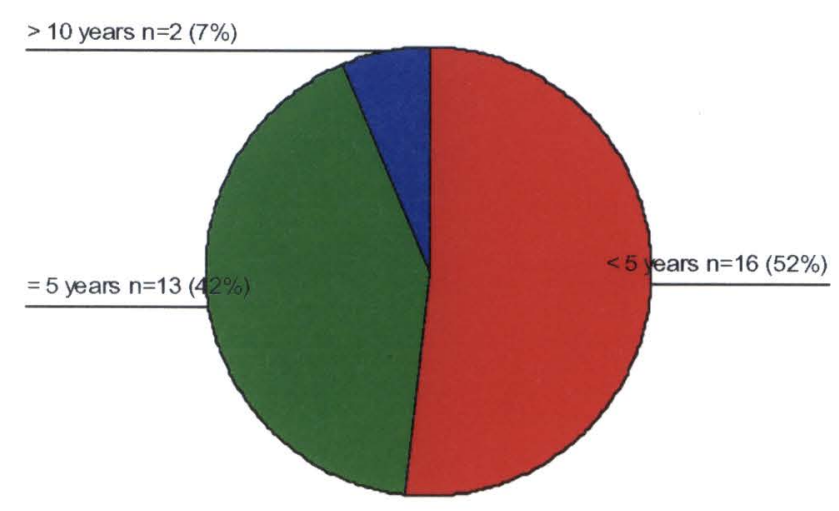

Manufacturing

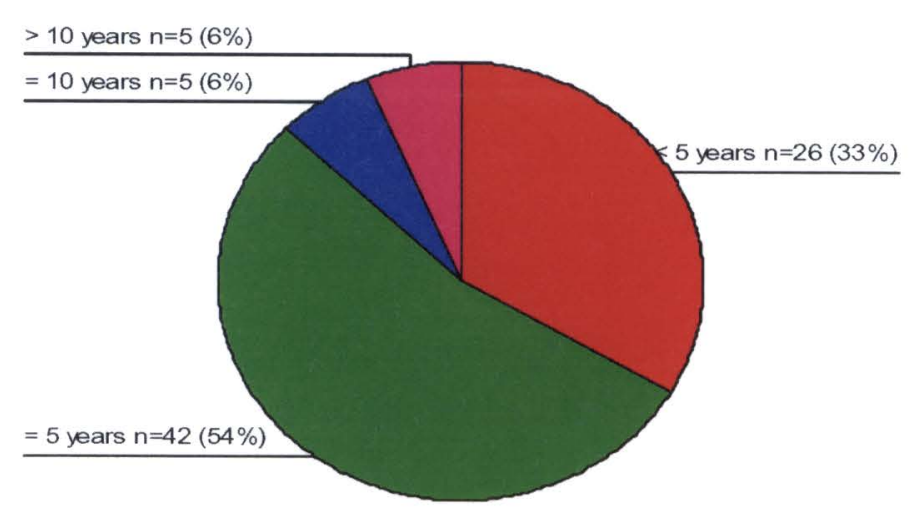

Other

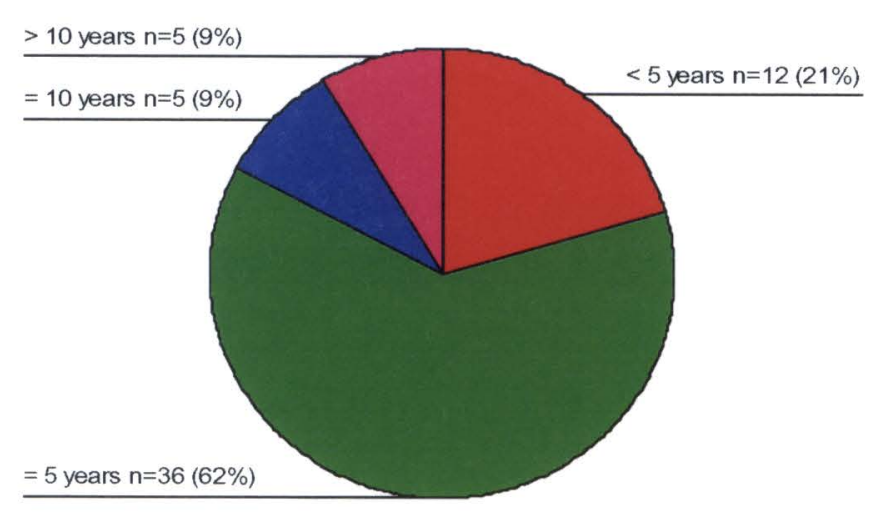


GRAPH 2.C.3 - OPTION HURDLES ACROSS INDUSTRY:

Mining

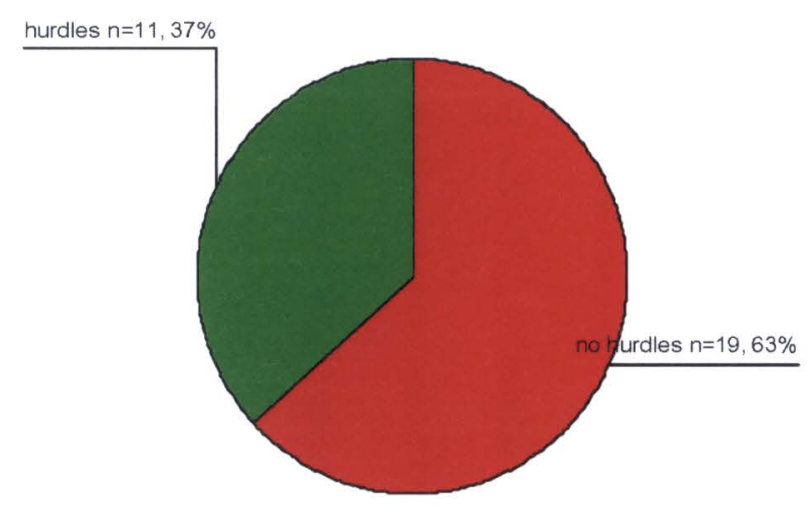

Banking \& Finance

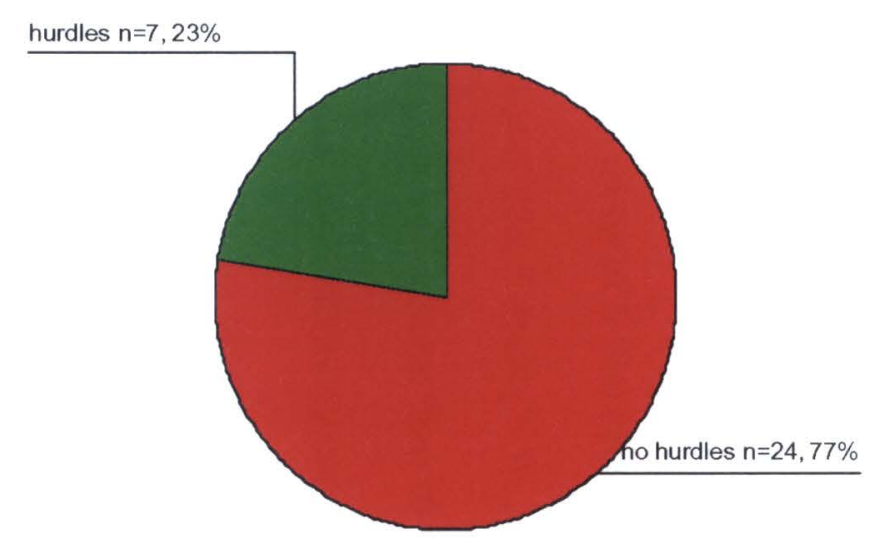

Manufacturing

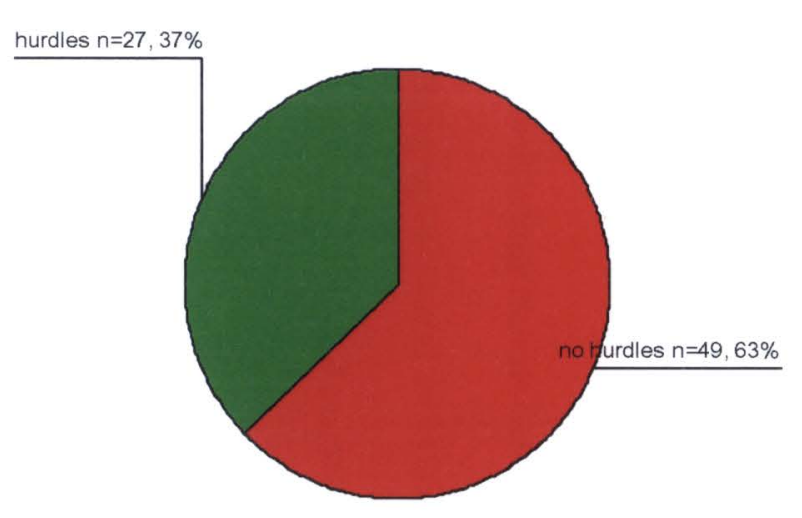

Other

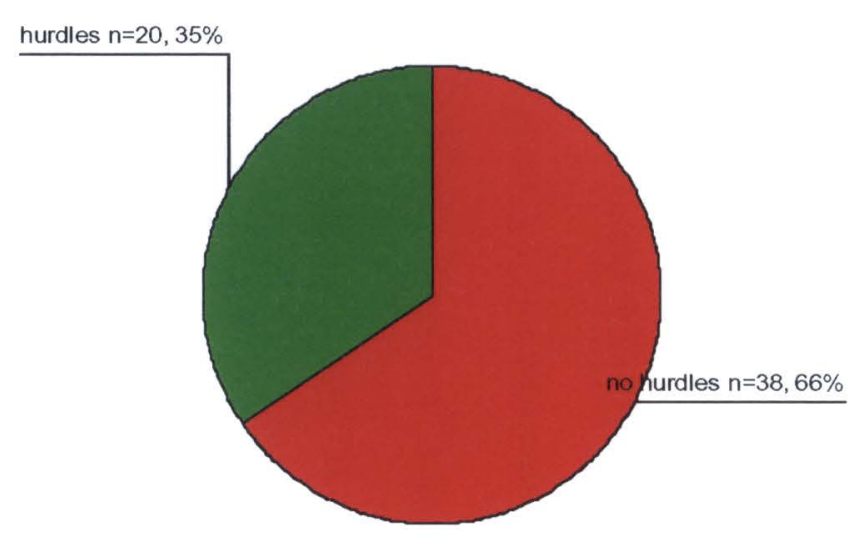


Graph 2.C.1 describes the exercise price details across the four industry groups. Fair market value (FMV) options ${ }^{18}$ are the most commonly awarded options across all industries [mining $57 \%$; manufacturing $53 \%$; banking and finance $71 \%$; other $43 \%$ ], but are the most dominant in the banking and finance industry. Premium options ${ }^{19}$ are the most frequently used in the other industry group (representing around $40 \%$ of the option grants), and least common in banking and finance ( $10 \%$ of grants), while they represent $27 \%$ of mining options and $31 \%$ of manufacturing options. Discount options ${ }^{20}$ are relatively similarly awarded across each of the industry groups, representing $17 \%$ of both mining and manufacturing options, and $19 \%$ of banking and finance and other options. Overall, the use of different exercise prices is relatively similar across the mining and manufacturing industries. Banking and finance appear to use far less premium options and substitute with FMV, while the other industry use relatively more premium and less FMV options.

Graph 2.C.2 shows the option terms across the industry groups, and indicates that the option terms are relatively similar across the mining, manufacturing and other industry, where these industries most commonly provide options with terms of 5 years $[67 \%, 54 \%$ and $62 \%$ respectively], followed by options with terms of less than 5 years $[27 \%, 33 \%$ and $21 \%$ ] and the least common being options with terms of equal or more than 10 years $[6 \%, 13 \%$ and $17 \%]$. While mining, manufacturing and other have relatively similar distributions of option terms, banking and finance give a much higher proportion of

\footnotetext{
${ }^{18}$ Exercise price $=$ stock price on date of issue of option.

${ }^{19}$ Exercise price $>$ stock price on date of issue of options

${ }^{20}$ Exercise price < stock price on date of issue of options
} 
options with terms of less than 5 years [52\%] and equal to 5 years [42\%], and a much lower proportion of options with terms of equal to or more than 10 years [7\%].

Finally, Graph 2.C.3 shows the occurrence of performance hurdles across the industry groups. Again, as with the option terms, the occurrence of hurdles is also relatively similar across mining, manufacturing and other industries [hurdles in place for $37 \%$, $37 \%$ and $35 \%$ of options for each industry respectively]. Again, banking and finance award different types of options, where performance hurdles are only attached to $23 \%$ of the option grants made in the sample period.

Overall, it appears that the option grant characteristics are relatively similar across the mining, manufacturing and other industries, while the banking and finance industry appear to have option characteristics possibly more beneficial to the CEO. 
APPENDIX 2.D:

COMBINATION OF OPTION GRANT CHARACTERISTICS ACROSS EACH OPTION

GRANT:

Table 2.D.1 shows the combinations of the option characteristics across the option grants:

Table 2.D.1- Combination of Option Grant Characteristics ACross Each OPTION GRANT (TOTAL N = 198):

Panel A - No performance hurdles attached:

\begin{tabular}{|c|c|c|c|c|c|}
\hline Option term: & $\begin{array}{l}<5 \text { years } \\
\mathrm{n}=\end{array}$ & $\begin{array}{l}=5 \text { years } \\
\mathrm{n}=\end{array}$ & $\begin{array}{l}=10 \text { years } \\
\mathrm{n}=\end{array}$ & $\begin{array}{l}>10 \text { years } \\
\mathrm{n}=\end{array}$ & $\begin{array}{l}\text { Total } \\
\mathrm{n}=\end{array}$ \\
\hline \multicolumn{6}{|l|}{ Exercise price: } \\
\hline FMV $n=$ & 11 & 41 & 3 & 4 & 59 \\
\hline Discount $\mathrm{n}=$ & 9 & 12 & 0 & 1 & 22 \\
\hline Premium $n=$ & 26 & 21 & 1 & 1 & 49 \\
\hline Total $\mathrm{n}=$ & 46 & 74 & 4 & 6 & 130 \\
\hline \multicolumn{6}{|c|}{ Panel B -Performance hurdles attached: } \\
\hline Option term: & $\begin{array}{l}<5 \text { years } \\
\mathrm{n}=\end{array}$ & $\begin{array}{l}=5 \text { years } \\
\mathrm{n}=\end{array}$ & $\begin{array}{l}=10 \text { years } \\
\mathrm{n}=\end{array}$ & $\begin{array}{l}>10 \text { years } \\
n=\end{array}$ & $\begin{array}{l}\text { Total } \\
\mathrm{n}=\end{array}$ \\
\hline \multicolumn{6}{|l|}{ Exercise price: } \\
\hline$F M V n=$ & 8 & 27 & 8 & 4 & 46 \\
\hline Discount $\mathrm{n}=$ & 4 & 7 & 0 & 2 & 13 \\
\hline Premium $n=$ & 4 & 3 & 0 & 1 & 8 \\
\hline Total $n=$ & 16 & 37 & 8 & 7 & 68 \\
\hline
\end{tabular}


Table 2.D.1 indicates that firms are using different combinations of option characteristics. What is particularly interesting is the occurrence of long option terms on the discount options, as short terms could be expected given that these options are already in the money. However, these options could also have some sort of employee retention aspect to them. On the other side, relatively short option terms are observed with the premium options, also interesting as it could be expected that the shorter the terms, the less likely that the exercise price is achieved. Finally, hurdles are used with all types of option grants. 


\section{APPENDIX 2.E:}

\section{OPTION GRANT CHARACTERISTICS OF FIRMS MAKING MULTIPLE OPTION}

\section{GRANTS:}

Also of interest is the variance in option grant behaviour by individual firms. All firms that made more than one option grant within the sample period were identified, and their use of different option characteristics is outlined in Table 2.E.1. The sample consists of 48 firms making a total of 123 option grants over the three years. The highest number of option grants made by a single firm was 7 , and the lowest 2 . Out of the 48 firms, 16 always used the same option characteristics in their option awards, while the remaining 32 firms had some variation.

Table 2.E.1- Option Grant Characteristics of Firms making Multiple OPTION GRANTS:

Panel A - Exercise prices:

\begin{tabular}{|l|c|c|c|c|c|c|c|c|}
\hline & \multicolumn{3}{|c|}{$\begin{array}{l}\text { Firms using same exercise } \\
\text { prices in each option grant } \\
\text { made: }\end{array}$} & \multicolumn{4}{|c|}{ Firms using a combination of exercise prices } \\
in their option grants: & \\
\hline & $\begin{array}{c}\text { All } \\
\text { FMV }\end{array}$ & $\begin{array}{c}\text { All } \\
\text { premium }\end{array}$ & $\begin{array}{c}\text { All } \\
\text { discount }\end{array}$ & $\begin{array}{c}\text { FMV \& } \\
\text { discount }\end{array}$ & $\begin{array}{c}\text { FMV \& } \\
\text { premium }\end{array}$ & $\begin{array}{c}\text { Premium } \\
\text { discount } \\
\text { fMV, }\end{array}$ & $\begin{array}{c}\text { FMscount } \\
\text { d } \\
\text { premium }\end{array}$ & Total \\
\hline $\begin{array}{l}\text { Number } \\
\text { of firms: }\end{array}$ & 18 & 7 & 5 & 4 & 9 & 2 & 3 & 48 \\
\hline
\end{tabular}

\begin{tabular}{|l|c|c|c|c|c|c|c|c|}
\hline \multicolumn{2}{|l|}{ Panel B - Option terms: } \\
\hline & $\begin{array}{c}\text { Firms using same option term } \\
\text { in each option grant made: }\end{array}$ & \multicolumn{2}{|c|}{$\begin{array}{c}\text { Firms using a combination of option terms } \\
\text { in their option grants: }\end{array}$} & \\
\hline & $\begin{array}{c}\text { All }<5 \\
\text { years }\end{array}$ & $\begin{array}{c}\text { All }=5 \\
\text { years }\end{array}$ & $\begin{array}{c}\text { All }=10 \\
\text { years }\end{array}$ & $\begin{array}{c}<5 \text { and }= \\
5 \text { years }\end{array}$ & $\begin{array}{c}=5 \&= \\
10 \\
\text { years }\end{array}$ & $\begin{array}{c}=5 \text { \& }>\text { yars } \\
10\end{array}$ & $\begin{array}{c}=5,10 \\
\&>10 \\
\text { years }\end{array}$ & Total \\
\hline $\begin{array}{l}\text { Number } \\
\text { of firms: }\end{array}$ & 11 & 21 & 1 & 9 & 2 & 3 & 1 & 48 \\
\hline
\end{tabular}




\begin{tabular}{|l|c|c|c|c|c|c|}
\hline \multicolumn{2}{|l|}{ Panel C - Performance hurdles: } \\
\hline $\begin{array}{c}\text { All } \\
\text { with } \\
\text { hurdles }\end{array}$ & $\begin{array}{c}\text { All } \\
\text { without } \\
\text { hurdles }\end{array}$ & $\begin{array}{c}\text { With hurdles, } \\
\text { change to } \\
\text { without } \\
\text { hurdles }\end{array}$ & $\begin{array}{c}\text { Without } \\
\text { hurdles, } \\
\text { change to } \\
\text { with hurdles }\end{array}$ & $\begin{array}{c}\text { Without hurdles 99, } \\
\text { with hurdles 00, } \\
\text { without in 01 }\end{array}$ & Total \\
\hline $\begin{array}{l}\text { Number } \\
\text { of firms: }\end{array}$ & 12 & 23 & 7 & 4 & 2 & 48 \\
\hline
\end{tabular}

Panel A of Table 2.E.1 provides counts of the firms' use of different exercise prices.

Out of the 48 firms, 30 always use the same exercise price type, leaving 18 that use some type of combination. The most popular combination is to offer FMV and premium options (9 firms), while only 3 firms use FMV, discount and premium options in the sample period. Of less variance is the use of option terms (Panel B), with 15 firms awarding options with different option terms over the sample period. Finally, Panel $\mathrm{C}$ shows that 13 firms have some change in the use of performance hurdles. Interestingly, the change for most of these firms was to change from using performance hurdles to having no hurdles in place ( 7 firms). As discussed previously, there is pressure on firms by shareholders to include performance hurdles, so this indication of a move away from performance hurdles is curious. 
APPENDIX 3A:

COMPENSATION GROUP AND FIRM CHARACTERISTICS BY INDUSTRY:

Tables 3A.1 through 3A.4 provide the descriptive results for the economic characteristics of firms by industry and compensation group: 
Table 3A.1 - Sample distribution and statistical differences across groups, Mining industry:

\begin{tabular}{|c|c|c|c|c|c|c|c|c|c|c|}
\hline & \multicolumn{4}{|c|}{ Equity } & \multicolumn{4}{|c|}{ Cash } & \multicolumn{2}{|c|}{ Equity group vs. Cash group } \\
\hline & $\mathrm{n}$ & Mean & Median & $\begin{array}{l}\text { Standard } \\
\text { deviation }\end{array}$ & $\mathrm{n}$ & Mean & Median & $\begin{array}{l}\text { Standard } \\
\text { deviation }\end{array}$ & $\begin{array}{c}\text { t-test } \\
(\mathrm{t})\end{array}$ & $\begin{array}{c}\text { Mann- } \\
\text { Whitney U }\end{array}$ \\
\hline Size $_{1-1}$ & 83 & 18.889 & 18.614 & 1.634 & 41 & 19.114 & 18.695 & 1.770 & -.705 & 1557 \\
\hline Size $_{t-1}-$ un-logged & 83 & $1,201,493$ & 120,843 & $4,959,333$ & 41 & 897,180 & 132,223 & $1,928,861$ & .489 & 1558 \\
\hline $\mathrm{MktBk}_{t-1}$ & 83 & 2.270 & 1.302 & 5.321 & 41 & 2.406 & 1.51 & 2.12 & -.158 & 1422 \\
\hline Decent $^{\mathrm{sub}}{ }_{t-1}$ & 83 & .479 & 2.398 & 4.704 & 41 & .525 & 1.792 & 4.283 & -.053 & 1496 \\
\hline Decent $^{\text {sub }}{ }_{t-1}$ - un-logged & 83 & 24.56 & 11.02 & 52.47 & 41 & 22.38 & 5.99 & 44.30 & .242 & 1496 \\
\hline Decent $^{\text {subfor }}{ }_{t-1}$ & 83 & -2.797 & 0 & 5.608 & 41 & -4.689 & -9.21 & 5.492 & $1.779^{*}$ & $1366^{*}$ \\
\hline Decent $^{\text {subior }}{ }_{t-1}-$ un-logged & 83 & 11.16 & 1 & 35.76 & 41 & 5.30 & 0 & 14.12 & 1.302 & $1366^{*}$ \\
\hline Noise $_{1-x}$ & 74 & .052 & .021 & .073 & 36 & .051 & .028 & .064 & .071 & 1275 \\
\hline $\operatorname{Cash}_{t-1}$ & 83 & .044 & .051 & .136 & 41 & .083 & .081 & .130 & -1.502 & 1496 \\
\hline CEOown $_{t-1}$ & 83 & .010 & .001 & .021 & 41 & .063 & .000 & .166 & $-2.857^{* * *}$ & 1612 \\
\hline
\end{tabular}

*** significant at the 0.01 level (2-tailed) ** significant at the 0.05 level (2-tailed) * significant at the 0.10 level (2-tailed)

Where:

Log of the market value of equity

Size, un-logged Market value of equity, rounded to the nearest $\$ \prime 000$

MktBk $_{t, l} \quad$ Market-to-book ratio

Decent ${ }^{20}\left({ }^{\prime \prime}\right) \quad$ Log of number of subsidiaries

Decent ${ }^{\text {sub }}{ }_{\text {b.1 }}$ - un-logged Number of subsidiaries

Log of number of foreign subsidiaries

Decent ${ }^{\text {subior }}{ }_{\text {i. }}$ - un-logged Number of foreign subsidiaries

Noise $_{1 . x} \quad$ Standard deviation of ROA over prior 3 years

Cashise

CEOown $_{m-1}$

$\%$ of operating cash flow over total assets

$\%$ of total common stock owned by the CEO over total common stock outstanding 
The results for the mining industry in Table 3A.1 show that industry does have an impact on the relation between firm characteristics and the structure of CEO compensation, as the mining industry results are quite different from the total sample. The equity mining firms are not significantly larger than the cash firms, do not have more growth options and are only slightly more decentralised. The only important difference appears to be CEO share ownership, where in the cash firms, the CEOs own more stock. These results could indicate that the level of CEO ownership is a sufficient criterion for the decision not to grant equity-based compensation, and / or that the proxies used to measure the other firm characteristics are weak for this industry. Alternatively, compensation contract choice in the mining industry could be determined by other factors that are not included in this analysis.

Table 3A.2 provides the descriptive results for the manufacturing industry: 
Table 3A.2 - Sample distribution and statistical differences across groups, Manufacturing industry:

\begin{tabular}{|c|c|c|c|c|c|c|c|c|c|c|}
\hline & \multicolumn{4}{|c|}{ Equity } & \multicolumn{4}{|c|}{ Cash } & \multicolumn{2}{|c|}{ Equity group vs. Cash group } \\
\hline & $\mathrm{n}$ & Mean & Median & $\begin{array}{l}\text { Standard } \\
\text { deviation }\end{array}$ & $\mathrm{n}$ & Mean & Median & $\begin{array}{l}\text { Standard } \\
\text { deviation }\end{array}$ & $\begin{array}{l}\text { t-test } \\
(t)\end{array}$ & $\begin{array}{c}\text { Mann- } \\
\text { Whitney U }\end{array}$ \\
\hline Size $_{t-1}$ & 193 & 19.318 & 19.026 & 1.41 & 82 & 18.580 & 18.311 & 1.315 & $4.163^{* * *}$ & $5388^{* * *}$ \\
\hline Size $e_{1-1}$ - un-logged & 193 & 723,081 & 183,918 & $1,330,564$ & 82 & 723,081 & 89,594 & 864,595 & $2.689^{* * *}$ & $5386 * * *$ \\
\hline $\mathrm{MktBk}_{t-1}$ & 193 & 4.264 & 1.874 & 6.966 & 82 & 2.443 & 1.636 & 2.404 & $3.209 * * *$ & $6659^{* *}$ \\
\hline $\operatorname{Decent}^{\mathrm{sub}}{ }_{1-1}$ & 193 & 1.987 & 2.708 & 3.460 & 82 & 1.40 & 2.350 & 3.638 & 1.242 & $6577^{* *}$ \\
\hline Decent $^{\text {sub }}{ }_{1-1}$ - un-logged & 193 & 36.53 & 15.03 & 56.12 & 82 & 19.21 & 10.50 & 24.25 & $3.574^{* * *}$ & $6577^{* * *}$ \\
\hline Decent $^{\text {subfor }}{ }_{t-1}$ & 193 & -.562 & 1.609 & 4.864 & 82 & -2.946 & 0 & 5.245 & $3.523^{* * *}$ & $5455^{* * *}$ \\
\hline Decent $_{\text {subfor }}{ }_{1-1}-$ un-logged & 193 & 13.79 & 5.00 & 23.91 & 82 & 4.15 & 1 & 9.26 & $4.817^{* * *}$ & $5455^{* * *}$ \\
\hline Noise $_{1 \cdot x}$ & 174 & .068 & .020 & .143 & 71 & .049 & .019 & .105 & 1.017 & 5980 \\
\hline Cash $_{1 \cdot l}$ & 193 & .058 & .068 & .141 & 82 & .068 & .077 & .114 & -.567 & 7440 \\
\hline CEOown $_{t-1}$ & 193 & .034 & .002 & .077 & 82 & .104 & .003 & .178 & $-4.557^{* * *}$ & 6991 \\
\hline
\end{tabular}

*** significant at the 0.01 level (2-tailed) ** significant at the 0.05 level (2-tailed) " significant at the 0.10 level (2-tailed)

Size...

Log of the market value of equity

MktBk,-loged Market-to-book ratio

Decent ${ }^{\mathrm{wub}}$ Log of number of subsidiaries

Decent ${ }^{\text {sub }}{ }^{\prime \prime-1}$ - un-logged Number of subsidiaries

Decent $t^{\text {strot }}{ }_{t .1}$ Log of number of foreign subsidiaries

Decent ${ }^{\text {subfor }}{ }_{1,-1}-$ un-logged $\quad$ Number of foreign subsidiaries

Noise $_{1-8} \quad$ Standard deviation of ROA over prior 3 years

The full sample results are mirrored in the manufacturing industry results, where the equity firms are larger, more complex, have more growth options and the CEO owns less shares. Table $3 \mathrm{~A} .3$ provides the descriptive results for the banking and finance industry: 
Table 3A.3 - Sample distribution and statistical differences across groups, Banking and Finance industry:

\begin{tabular}{|c|c|c|c|c|c|c|c|c|c|c|}
\hline & \multicolumn{4}{|c|}{ Equity } & \multicolumn{4}{|c|}{ Cash } & \multicolumn{2}{|c|}{ Equity group vs. Cash group } \\
\hline & $\mathrm{n}$ & Mean & Median & $\begin{array}{l}\text { Standard } \\
\text { deviation }\end{array}$ & $\mathrm{n}$ & Mean & Median & $\begin{array}{l}\text { Standard } \\
\text { deviation }\end{array}$ & $\begin{array}{l}\text { t-test } \\
(t)\end{array}$ & $\begin{array}{c}\text { Mann- } \\
\text { Whitney U }\end{array}$ \\
\hline Size $_{\ell-1}$ & 45 & 21.051 & 21.269 & 2.383 & 29 & 19.314 & 19.325 & 1.264 & $4.075^{* * *}$ & $370^{* * *}$ \\
\hline Size $_{t-l}$ - un-logged & 45 & $8,205,556$ & $1,727,602$ & $11,870,926$ & 29 & 540,898 & 245,793 & 889,731 & $4.312 * * *$ & $369 * * *$ \\
\hline $\mathrm{MktBk}_{t-1}$ & 45 & 2.324 & 1.934 & 2.192 & 29 & 2.866 & 1.256 & 3.792 & -.698 & 591 \\
\hline Decent $^{\text {sub }}{ }_{1-1}$ & 45 & 3.321 & 3.714 & 2.361 & 29 & -.128 & 1.946 & 4.824 & $3.584^{* * *}$ & $262^{* * *}$ \\
\hline Decent $^{\text {sub }}{ }_{1-1}$ - un-logged & 45 & 81.42 & 10.85 & 103.69 & 29 & 12.91 & 7.03 & 16.60 & $4.347^{* * *}$ & $262^{* * *}$ \\
\hline Decent $^{\text {subfot }}$ & 45 & -1.672 & 1.097 & 6.052 & 29 & -5.831 & -9.21 & 5.157 & $3.161^{* * *}$ & $383^{* * *}$ \\
\hline Decent $^{\text {subfor }}{ }_{1-l}-$ un-logged & 45 & 27.50 & 3.00 & 58.72 & 29 & 2.76 & 0 & 6.77 & $2.798^{* * *}$ & $383^{* * *}$ \\
\hline Noise $_{t \cdot x}$ & 37 & .048 & .019 & .063 & 28 & .0681 &, 045 & .085 & -1.055 & 405 \\
\hline $\operatorname{Cash}_{1-1}$ & 45 & .054 & .059 & .168 & 29 & .087 & .079 & .058 & -1.226 & 529 \\
\hline CEOown $_{t-1}$ & 45 & .032 & .000 & .074 & 29 & .064 & .000 & .152 & -1.076 & 574 \\
\hline
\end{tabular}

*** significant at the 0.01 level (2-tailed) ** significant at the 0.05 level (2-tailed) * significant at the 0.10 level (2-tailed) Where:

Size,

Size,t,l un-logged

$\mathrm{MktBk}_{t, 1}$

Decent ${ }^{30 b}$ i.1

Decent ${ }_{1.1}^{\text {at }}$ - un-logged

Decent ${ }^{\text {subfor }}{ }^{\prime \prime}$

Decent ${ }^{\text {utbror }}{ }_{t, 1}$ - un-logged

Log of the market value of equity

Market value of equity, rounded to the nearest $\$ 000$

Market-to-book ratio

Log of number of subsidiaries

Number of subsidiaries

Log of number of foreign subsidiaries

Number of foreign subsidiaries

Standard deviation of ROA over prior 3 years 
Similar to the manufacturing industry, the results for the banking and finance industry indicate that size and complexity are important determinants of compensation choice. However, while insignificantly different, the equity firms also have less growth options, which is contra to expectations. As with the mining firms, this result could indicate that our proxy of the market-to-book ratio does not describe growth options in the banking and finance industry well. Also interesting is that CEO share ownership is not significantly different between the two groups.

Table 3A.4 provides the descriptive results for the Other industry: 
Table 3A.4 - Sample distribution and statistical differences across groups, Other industry:

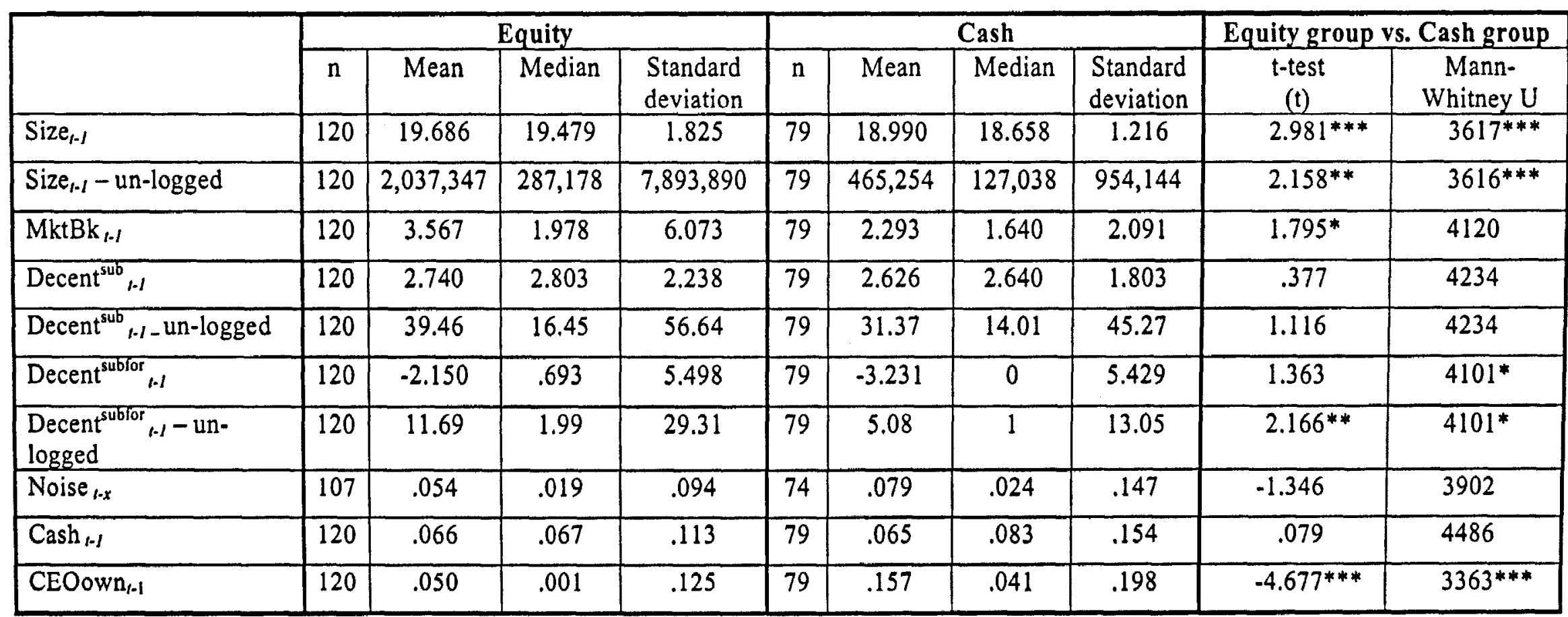

*** significant at the 0.01 level (2-tailed) ** significant at the 0.05 level (2-tailed) " significant at the 0.10 level (2-tailed)

Where:

Size $t_{\text {.t }} \quad$ Log of the market value of equity

Size,-1 un-logged Market value of equity, rounded to the nearest $\$$ '000

MktBk $\quad$ Market-to-book ratio

Decent ${ }^{20}$ Log of number of subsidiaries

Decent ${ }^{\mathrm{sub}}{ }_{t-1}$ - un-logged Number of subsidiaries

Log of number of foreign subsidiaries

Decent ${ }^{u b t o r}{ }_{t, l}$ - un-logged Number of foreign subsidiaries

Noise $_{1 . x} \quad$ Standard deviation of ROA over prior 3 years

The main differences in economic characteristics between the compensation groups in the other industry appear to be firm size and

CEO share ownership. 
APPENDIX 4.A:

\section{THE STRUCTURE OF OPTION AWARDS AND FIRM PERFORMANCE:}

The performance consequences of different types of option grant are investigated. The original sample from Chapter Two has 163 firms making 198 option grants. Multiple option grants were excluded, so that each firm could only have a maximum of one option grant in any year. Also deleted were all of the option grants made by five firms which used a multiple of different types of option characteristics (for example, some firms granted options both at fair market value (FMV) and at a discount in the same year). The final sample consists of 156 firms, and the descriptive statistics for the performance variables are described in Table 4.A.1 below:

Table 4.A.1 - Descriptive statistics - performance of option granting firms, total sample:

\begin{tabular}{|l|l|c|c|c|c|}
\hline & & \multicolumn{4}{|c|}{ Total } \\
\hline \multirow{3}{*}{ Total } & & $\mathrm{n}$ & Mean & Median & $\begin{array}{c}\text { Standard } \\
\text { deviation }\end{array}$ \\
\hline & ROA & 156 & .063 & .079 & .098 \\
\cline { 2 - 6 } & ROE & 156 & .079 & .095 & .161 \\
\cline { 2 - 6 } & $\Delta \mathrm{MVE}$ & 156 & .244 & .167 & .655 \\
\cline { 2 - 6 } & DMVErisk & 96 & .141 & .106 & .680 \\
\hline
\end{tabular}

where:

$\mathrm{ROA}=$ return on total average assets

$\mathrm{ROE}=$ return on total average equity

$\triangle M V E=$ percentage change in total market value of common equity, adjusted for dividends

$\triangle M V E r i s k=$ percentage change in total market value of common equity, adjusted for dividends and risk

Comparing Table 4.A.1 to Table 4.3 in Chapter 4 indicates that the firms in the equity group that awarded equity during the sample period have better market performance compared to the total firms in the equity group (average of $24.4 \%$ compared to $9 \%$ in 
Table 4.3 Chapter 4 ). This could imply that firms that award equity perform better in the years in which the equity grant is made or alternatively that firms tend to award equity in the years in which market performance is higher.

\section{A.1 PerformanCE ANd Option Terms:}

Tables 4.A.2A and 4.A.2B present the descriptive and performance results of option terms:

TABLE 4.A.2A - DESCRIPTIVE STATISTICS - PERFORMANCE OF OPTION GRANTING FIRMS, BY OPTION TERM:

\begin{tabular}{|c|c|c|c|c|c|c|c|c|}
\hline \multirow{2}{*}{$\begin{array}{l}\text { Option } \\
\text { term: }\end{array}$} & \multicolumn{4}{|c|}{$<5$ years } & \multicolumn{4}{|c|}{$=5$ years } \\
\hline & $\mathbf{n}$ & Mean & Median & $\begin{array}{l}\text { Standard } \\
\text { deviation }\end{array}$ & $\mathrm{n}$ & Mean & Median & $\begin{array}{l}\text { Standard } \\
\text { deviation }\end{array}$ \\
\hline $\mathrm{ROA}$ & 45 & .062 & .0731 & .099 & 89 & .067 & .081 & .101 \\
\hline ROE & 45 & .098 & .090 & .174 & 89 & .070 & .100 & .159 \\
\hline$\Delta \mathrm{MVE}$ & 45 & .295 & .256 & .758 & 89 & .221 & .165 & .600 \\
\hline$\Delta$ MVErisk & 23 & .170 & .008 & .762 & 55 & .146 & .158 & .663 \\
\hline \multirow[t]{2}{*}{$\begin{array}{l}\text { Option } \\
\text { term: }\end{array}$} & \multicolumn{4}{|c|}{$F 10$ years } & \multicolumn{4}{|c|}{$>10$ years } \\
\hline & $\mathrm{n}$ & Mean & Median & $\begin{array}{r}\text { Standard } \\
\text { deviation }\end{array}$ & $\mathrm{n}$ & Mean & Median & $\begin{array}{l}\text { Standard } \\
\text { deviation }\end{array}$ \\
\hline $\mathrm{ROA}$ & 10 & .036 & .068 & .095 & 12 & .055 & .080 & .083 \\
\hline ROE & 10 & .038 & .085 & .141 & 12 & .120 & .140 & .144 \\
\hline$\triangle \mathrm{MVE}$ & 10 & .163 & -.141 & .834 & 12 & .298 & .294 & .535 \\
\hline DMVErisk & 8 & .064 & -.376 & .957 & 10 & .102 & .178 & .322 \\
\hline
\end{tabular}

where:

$\mathrm{ROA}=$ return on total average assets ROE = return on total average equity $\triangle M V E$ = percentage change in total market value of common equity, adjusted for dividends $\triangle M V E r i s k=$ percentage change in total market value of common equity, adjusted for dividends and risk 
TABle 4.A.2B - PerformanCe ANd OPTION TERMS:

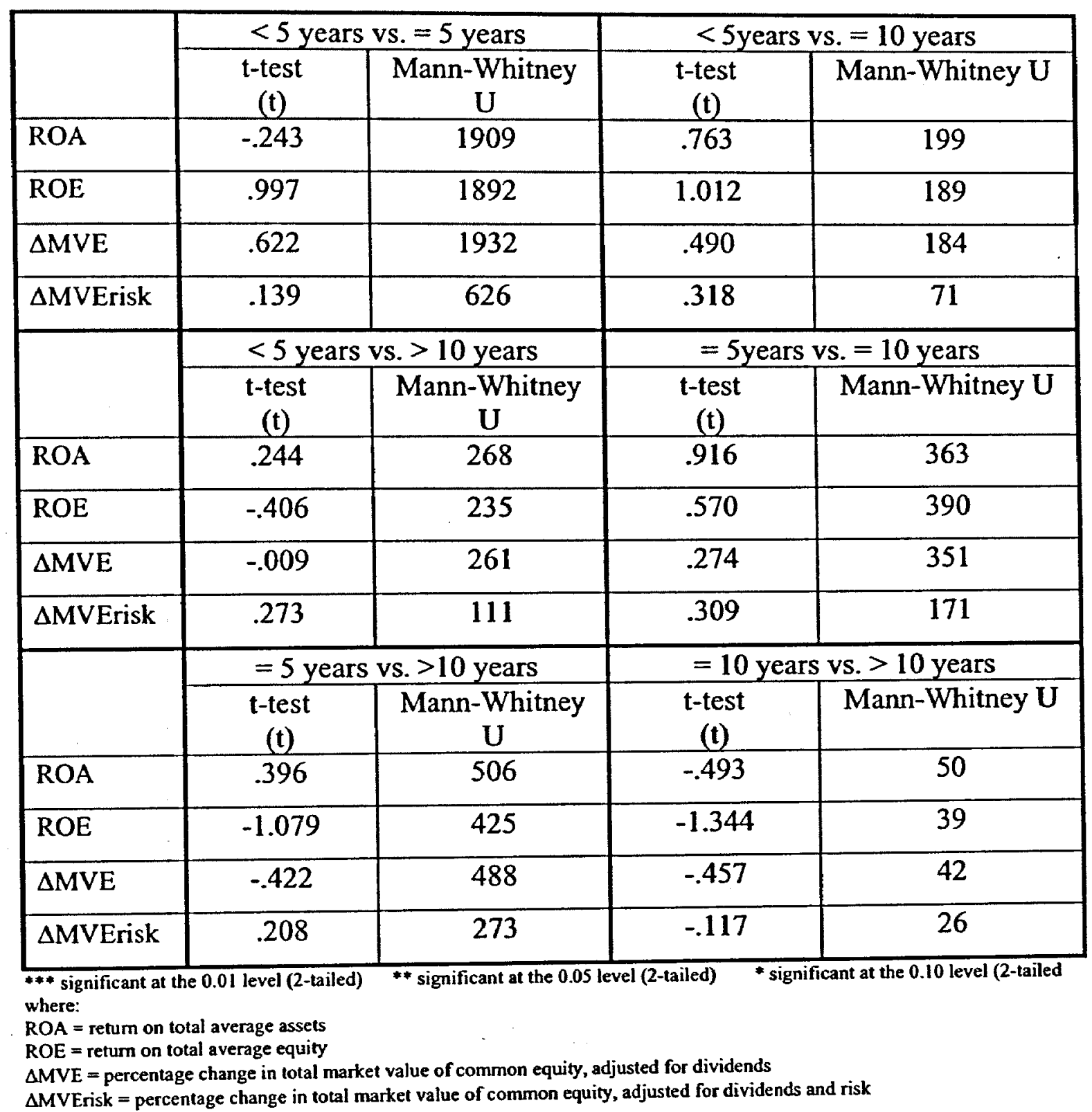

The option term descriptive statistics in Table 4.A.2A indicate that performance does vary across firms using the different terms, with the lowest performance in the $=10$ year group. Table 4.A.2B shows that none of these differences were significant. This indicates that these firms are choosing option terms for certain reasons, and option term itself will not result in better or worse firm performance. 


\section{A.2 Performance and Option EXercise Prices:}

Tables 4.A.3A and 4.A.3B present the descriptive and performance results of exercise prices:

TABLE 4.A.3A - DESCRIPTIVE STATISTICS - PERFORMANCE OF OPTION GRANTING FIRMS, BY EXERCISE PRICE TYPE:

\begin{tabular}{|c|c|c|c|c|c|c|c|c|}
\hline \multirow{2}{*}{$\begin{array}{l}\text { Exercise } \\
\text { Price: }\end{array}$} & \multicolumn{4}{|c|}{ Fair market value } & \multicolumn{4}{|c|}{ Discount $^{21}$} \\
\hline & $\mathbf{n}$ & Mean & Median & $\begin{array}{l}\text { Std } \\
\text { dev }\end{array}$ & $\mathrm{n}$ & Mean & Median & $\begin{array}{l}\text { Std } \\
\text { dev }\end{array}$ \\
\hline ROA & 90 & .066 & .078 & .092 & 26 & .075 & .097 & .108 \\
\hline ROE & 90 & .096 & .130 & .148 & 26 & .079 & .115 & .178 \\
\hline$\triangle \mathrm{MVE}$ & 90 & .234 & .162 & .544 & 26 & .460 & .351 & .882 \\
\hline$\triangle M V E r i s k$ & 57 & .104 & -.004 & .607 & 20 & .180 & .241 & .814 \\
\hline \multirow{2}{*}{$\begin{array}{l}\text { Exercise } \\
\text { Price: }\end{array}$} & \multicolumn{4}{|c|}{ Premium $^{22}$} & & & & \\
\hline & $\mathbf{n}$ & Mean & Median & $\begin{array}{l}\text { Std } \\
\text { dev }\end{array}$ & & & & \\
\hline ROA & 40 & .046 & .067 & .105 & & & & \\
\hline ROE & 40 & .039 & .055 & .175 & & & & \\
\hline$\triangle \mathrm{MVE}$ & 40 & .127 & -.014 & .698 & & & & \\
\hline$\triangle$ MVErisk & 19 & .210 & .158 & .767 & & & & \\
\hline $\begin{array}{l}\text { where: } \\
\text { ROA = return } \\
\text { ROE }=\text { return } \\
\triangle M V E=\text { perce } \\
\Delta M V E r i s k=p\end{array}$ & han & $y$ & ons & , yous, & & is & & \\
\hline
\end{tabular}

\footnotetext{
${ }^{21}$ Exercise Price < fair market value

${ }^{2}$ Exercise Price $>$ fair market value
} 
TABLe 4.A.3B-PERformanCe AND EXerCise Prices:

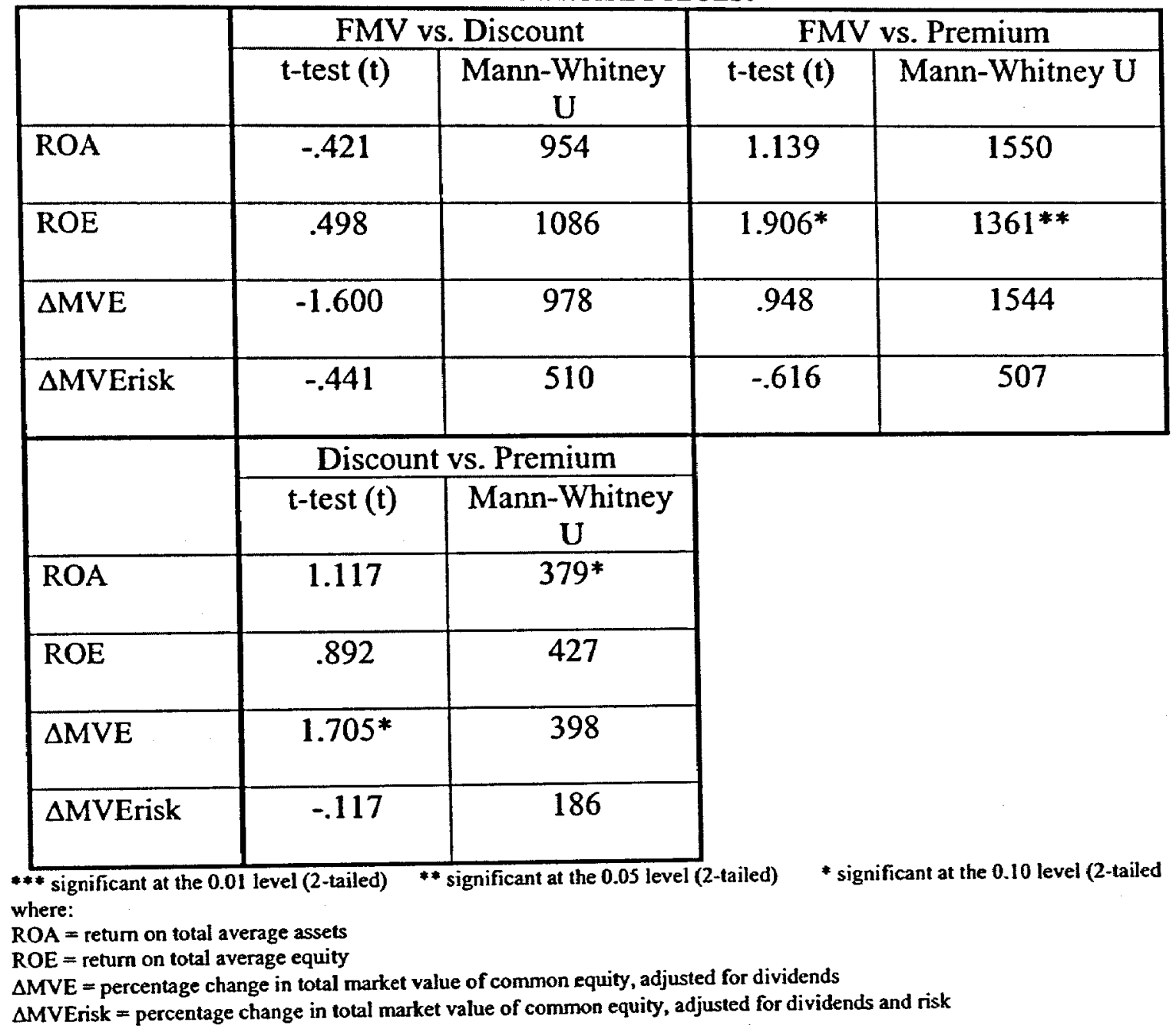

Table 4.A.3B shows some marginally significant differences in the performance across firms using different option exercise price types. ROE is weakly significantly higher in the FMV option firms compared to the premium option firms, although there are no differences in market returns. There are marginally significant differences in market returns between the discount and premium firms, with discount firms having higher market returns, unadjusted for risk. However, this result disappears once returns are risk adjusted. This result could indicate that discount firms are more risky, and that in firms 
with very high risk, discount options are used to help mitigate some of the risk faced by the CEO.

\section{A.3 Performance and Option HuRdles:}

Tables 4.A.4A and 4.A.4B present the descriptive and performance results of hurdles:

\section{TABLE 4.A.4A - DESCRIPTIVE STATISTICS - PERFORMANCE OF OPTION GRANTING}

FIRMS, BY HURDLES:

\begin{tabular}{|l|c|c|c|c|c|c|c|c|}
\hline Hurdles: & \multicolumn{4}{|c|}{ No Hurdles } & \multicolumn{4}{c|}{ Hurdles } \\
\hline & $\mathrm{n}$ & Mean & Median & $\begin{array}{c}\text { Std } \\
\mathrm{dev}\end{array}$ & $\mathrm{n}$ & Mean & Median & $\begin{array}{c}\text { Std } \\
\text { dev }\end{array}$ \\
\hline ROA & 97 & .044 & .067 & .101 & 59 & .093 & .084 & .087 \\
\hline ROE & 97 & .057 & .090 & .171 & 59 & .114 & .110 & .137 \\
\hline$\Delta$ MVE & 97 & .282 & .256 & .698 & 59 & .183 & .125 & .580 \\
\hline$\Delta$ MVErisk & 55 & .174 & .158 & .728 & 41 & .096 & -.004 & .617 \\
\hline
\end{tabular}

where:

$\mathrm{ROA}=$ return on total average assets

ROE = return on total average equity

$\triangle M V E=$ percentage change in total market value of common equity, adjusted for dividends

$\triangle M V E r i s k$ = percentage change in total market value of common equity, adjusted for dividends and risk

TABLe 4.A.4B - Performance AND HuRdles:

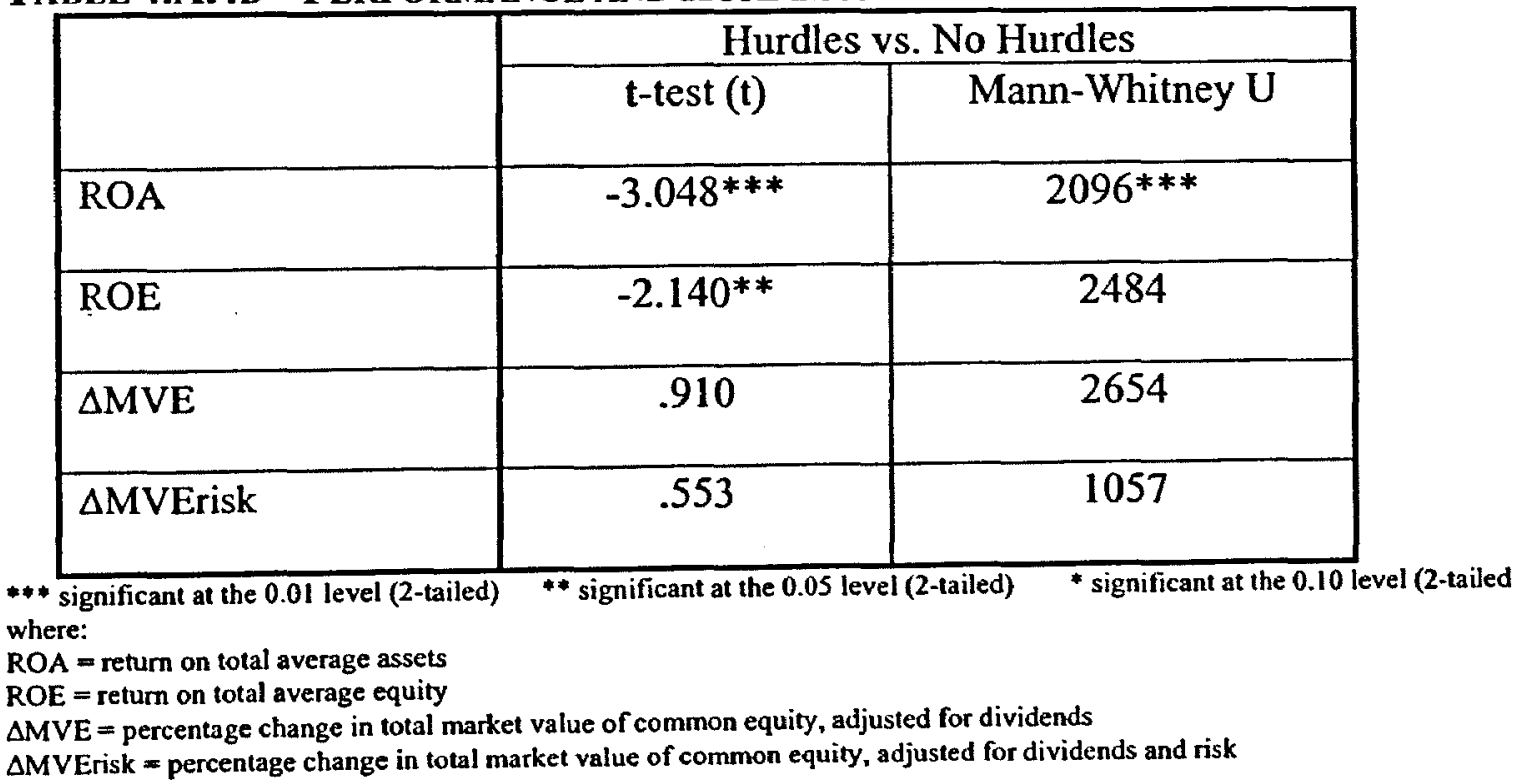


The descriptive statistics indicated that hurdle firms had better accounting performance but worse market performance compared to the non hurdle firms. Table 4.A.4B shows that these differences in accounting performance are significant, especially in relation to ROA, but the differences in market performance are not significant. These results could be driven by the type of hurdles that are in place, however, it is impossible to obtain detailed information as to the exact nature of the hurdles in place in each individual company. Although accounting performance is better, this does not seem to translate into improved market performance.

\section{A.4 COMBINATION OF OPTION CHARACTERISTICS:}

Finally, all option characteristics are tested together. In order to do this, an OLS regression is estimated where firm performance is regressed on the three option characteristics as well as other controls for performance, and the results are reported in Table 4.A.5: 


\section{TABLE 4.A.5 - SUMMARY OF THE OLS REgRESSION COEFFICIENTS FOR THE RELATION

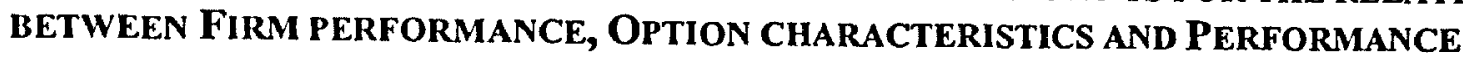 \\ CONTROLS:}

The coefficients are based on the following equation: Perf $_{i t}=\eta_{0}+\eta_{1}$ Option term $_{\text {it }}+\eta_{2}$ Exercise price $_{\text {if }}+\eta_{3}$ Hurdles $_{\text {in }}$

\begin{tabular}{|c|c|c|c|c|c|c|c|}
\hline \multirow[t]{2}{*}{ Variables: } & \multirow{2}{*}{$\begin{array}{l}\text { Predicted } \\
\text { sign }\end{array}$} & \multicolumn{6}{|c|}{ Firm performance } \\
\hline & & $\begin{array}{c}\text { ROE } \\
n=156\end{array}$ & $\begin{array}{c}\mathrm{ROA} \\
\mathrm{n}=156\end{array}$ & $\begin{array}{c}\Delta \mathrm{MVE} \\
\mathrm{n}=156\end{array}$ & $\begin{array}{c}\Delta \text { MVErisk } \\
n=96\end{array}$ & $\begin{array}{c}\Delta M V E \\
n=156\end{array}$ & 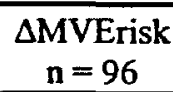 \\
\hline Intercept & $+1-$ & $\begin{array}{c}.073 \\
(1.235) \\
\end{array}$ & $\begin{array}{r}.022 \\
(.623) \\
\end{array}$ & $\begin{array}{c}.528 \\
\left(2.162^{* *}\right)\end{array}$ & $\begin{array}{l}.172 \\
(.502) \\
\end{array}$ & $\begin{array}{c}1.070 \\
\left(1.738^{*}\right)\end{array}$ & $\begin{array}{c}-.074 \\
(-.088)\end{array}$ \\
\hline Option term ${ }_{i l}$ & $+1-$ & $\begin{array}{c}-.024 \\
(-1.515)\end{array}$ & $\begin{array}{c}-.052 \\
(-.539)\end{array}$ & $\begin{array}{l}-.056 \\
(-.844)\end{array}$ & $\begin{array}{c}.041 \\
(.428)\end{array}$ & $\begin{array}{c}-.061 \\
(-.917)\end{array}$ & $\begin{array}{c}.045 \\
(.459)\end{array}$ \\
\hline $\begin{array}{l}\text { Exercise } \\
\text { price }_{i}\end{array}$ & +1 & $\begin{array}{c}-.011 \\
(-.893)\end{array}$ & $\begin{array}{c}-.097 \\
(-1.336)\end{array}$ & $\begin{array}{c}-.013 \\
(-.252)\end{array}$ & $\begin{array}{c}-.010 \\
(-.162)\end{array}$ & $\begin{array}{c}-.019 \\
(-.375)\end{array}$ & $\begin{array}{c}-.097 \\
(-.153)\end{array}$ \\
\hline Hurdles $_{i t}$ & $+1-$ & $\begin{array}{c}.050 \\
\left(1.819^{*}\right)\end{array}$ & $\begin{array}{c}.050 \\
\left(3.036^{* * *}\right)\end{array}$ & $\begin{array}{c}-.119 \\
(-1.044)\end{array}$ & $\begin{array}{c}-.053 \\
(-.352)\end{array}$ & $\begin{array}{c}-.105 \\
(-.923)\end{array}$ & $\begin{array}{c}-.049 \\
(-.319)\end{array}$ \\
\hline Size $_{\ell *}$ & - & & & & & $\begin{array}{c}-.025 \\
(-.894)\end{array}$ & $\begin{array}{c}.013 \\
(.344) \\
\end{array}$ \\
\hline $\mathrm{MktBk}_{t-1}$ & + & & & & & $\begin{array}{c}-.015 \\
(-.994)\end{array}$ & $\begin{array}{c}-.064 \\
(-.347) \\
\end{array}$ \\
\hline Adjusted $R^{2}$ & & .026 & .050 & -.010 & -.026 & -.008 & -.047 \\
\hline$F$ ratio & & $2.389^{*}$ & $3.702^{* * *}$ & .512 & .188 & .765 & .153 \\
\hline
\end{tabular}

*** significant at the 0.01 level (2-tailed). ** significant at the 0.05 level (2-tailed) * significant at the 0.10 level (2-tailed)

Where:

Perf Firm performance as described in table above

Option Term ${ }_{i 1} \quad$ Dummy variable for the term of the option, taking the value of 1 for $<5$ years; 2 for $=5$ years; 3 for between 5 and 10 years; 4 for $=10$ years and $5>10$ years

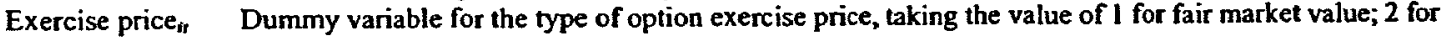
discount and 3 for premium

Hurdles $\quad$ Dummy variable for the existence of hurdles, taking the value of 1 for no hurdles, and 2 if hurdles are in

$\begin{array}{ll} & \text { place } \\ \text { Size }_{t-1} & \text { Log of market value of equity }\end{array}$

MktBk $_{\text {i-l }} \quad$ Market-to-book ratio

The F ratios in Table 4.A.5 indicate that, of the market performance models, none is significant, and only weak significance is found for the accounting return models. The ROE model is only significant at the $10 \%$ level, and the only variable with any power is hurdles. More significant is the ROA model (significance $=1.3 \%$ ), and again the only individually significant variable is the presence of hurdles - there is a positive relation between the existence of hurdles and accounting performance. These results confirm the univariate findings in Tables 4.A.2B through 4.A.4B - option terms and option 
exercise prices are not related to firm performance, but the existence of hurdles is positively related to accounting performance. 


\section{REFERENCES:}

Aboody, D (1996) “Market valuation of employee stock options" Journal of Accounting and Economics 22, 337-91

Angbazo, L. and Narayanan, R. (1997) "Top management compensation and the structure of the board of directors in commercial banks" European Finance Review 1, 239-259.

ASX Corporate Governance Council (2003) Principles of Good Corporate Governance and Best Practice Recommendations, Australian Stock Exchange, Sydney.

Banker, R.D. and Datar, S.M. (1989) "Sensitivity, precision, and linear aggregation of signals for performance evaluation" Journal of Accounting Research 27, 21-39.

Beatty, R.P. and E.J. Zajac (1994) "Managerial incentives, monitoring, and risk bearing: A study of executive compensation, ownership, and board structure in initial public offerings" Administrative Science Quarterly 39, 313-335

Bebchuk, L., J. Fried and D. Walker (2002) "Managerial power and rent extraction in the design of executive compensation" University of Chicago Law Review, Summer 69(3), $751-842$ 
Black, F. and M. Scholes (1973) “The pricing of options and corporate liabilities" Journal of Political Economy 81, 637-659

Brown, P. and E, Yew (2002) "How do investors regards ESOs?" Australian Accounting Review 12(1) 36-42

Bushman, R.M. and A.J. Smith (2001) "Financial accounting information and corporate governance" Journal of Accounting and Economics 32, 237-333.

Cheung, J and A. Marsden (1998) "Unwarranted Estimates" JASSA, Winter, 6-9

Core, J.E. and W. Guay (1999) "The use of equity grants to manage optimal equity incentive levels" Journal of Accounting and Economics 28, 151-184.

Core, J.E. and W. Guay (2001) "Stock option plans for non-executive employees" Journal of Financial Economics 61, 253-287

Core, J.E., W. Guay and D.F. Larcker (2003) "Executive equity compensation and incentives: A survey" Economic Policy Review 27-50

Core, J.E., R.W. Holthausen and D.F. Larcker (1999) “Corporate governance, chief executive officer compensation, and firm performance", Journal of Financial Economics $51,371-406$. 
Coulton, J. and S. Taylor (2002a) "Option awards for Australian CEOs: The Who, What and Why" Australian Accounting Review, 12(1), 25-35.

Coulton, J. and S. Taylor (2002b) “Accounting for executive stock options: a case study in avoiding tough decisions" Australian Accounting Review, 12(1) 1, 3-10.

Crease, S., Goodwin, J. and Kent, P. (2001) "The incentives of Australian companies to utilise executive stock option plans" working paper, University of Queensland.

Cullen Egan Dell (1997) Executive incentive plans in Australia

Datar, S., S.C. Kulp and R.A. Lambert (2001) "Balancing performance measures" Journal of Accounting Research 39(1), 75-92

Defina, A., T.C. Harris and I.M. Ramsay (1994) "What is reasonable remuneration for corporate officers? An empirical investigation into the relationship between pay and performance in the largest Australian companies" Company and Securities Law Journal (12) $341-356$

Demsetz, H. and K. Lehn (1985) "The structure of corporate ownership: causes and consequences" Journal of Political Economy 93(6), 1155-1177. 
Fama, G. and K French (1992) "The cross-section of expected returns" Journal of Finance 47, 427-465

Frye, M.B. (2001) “Equity-based compensation for employees: firm performance and determinants" working paper, University of Central Florida

Gaver, J.J. and K.M. Gaver (1993) "Additional evidence on the association between the investment opportunity set and corporate financing, dividend and compensation policies" Journal of Accounting and Economics 16, 125-160.

Gibbons, R. and K, Murphy (1990) "Relative performance evaluation for chief executive officers" Industrial and Labor Relations Review 43(3), 30s-51s

Grossman, S.J. and Hart, O.D. (1983) "An analysis of the principal agent problem' Econometrica 51, 7-45.

Guay, W.R. (1999) "The sensitivity of CEO wealth to equity risk: an analysis of the magnitude and determinants" Journal of Financial Economics 53, $43-71$.

Hall, B. and J. Liebman (1998) “Are CEOs really paid like bureaucrats?” Quarterly Journal of Economics 113 (3), 653-691 
Hall, B. and K. Murphy (2000) "Optimal exercise prices of executive stock options" American Economic Review 90, 209-214

Harris, M. and Raviv, A. (1979) "Optimal incentive contracts with imperfect information" Journal of Economic Theory 20, 231-259.

Hay Management Consultants (1991) Hay Group Survey of Short Term Incentive Plan Practice

Hermalin, B.E. and N.E. Wallace (2001) "Firm performance and executive compensation in the savings and loan industry" Journal of Financial Economics 61,139 170

Hermalin, B. and Weisbach, M. (1988) "The determinants of board composition" $\underline{\text { Rand }}$ Journal of Economics 19, 589-606.

Hirshleifer, D. and Suh, Y. (1992) "Risk, managerial effort and project choice" Journal of Financial Intermediation

Holmstrom, B. (1979) “Moral hazard and observability" Bell Journal of Economics 10, 74-91. 
Huddart, S. (1994) "Employee stock options" Journal of Accounting and Economics 18, $207-231$

Ittner, C.D., R.A. Lambert and D.F. Larcker (2003) "The structure and performance consequences of equity grants to employees of new economy firms" Journal of Accounting and Economics 34, 89-127

Izan, H.Y., B. Sidhu and S. Taylor (1998) "Does CEO pay reflect performance? Some Australian evidence" Corporate Governance 6(1), 39-47

Jensen, M.C. and Meckling, W.H. (1976) "Theory of the firm: Managerial behaviour, agency costs and ownership structure" Joumal of Financial Economics 3, 305-360.

Jensen, M.C. and Murphy, K.J. (1990) “CEO incentives - it's not how much you pay, but how" Harvard Business Review 68, 138-153.

Jensen, M.C., Murphy, K.J. and Wruck, E.G. (2004) "Remuneration: Where We've Been, How We Got to Here, What are the Problems, and How to Fix Them" working paper, SSRN

Lambert, R.A. and D.F. Larcker (1987) “An analysis of the use of accounting and market measures of performance in executive compensation contracts" Journal of Accounting Research 25, supplement, 85-129 
Lambert, R., D Larcker and R. Verrecchia (1991) "Portfolio considerations in valuing executive compensation" Journal of Accounting Research 29, 129-149

Maller, R., R. Tan and M. van de Vyver (2002) "How might companies value ESOs?" Australian Accounting Review 12(1), 11-24

Matolcsy, Z.P., (2000) "Executive cash compensation and corporate performance during different economic cycles" Contemporary Accounting Research 17(4), 671-692

McConnell, P (1993) “Accounting for employee stock options: crystal ball gazing" Bear Stearns and Co., Inc. Investment Research

Mehran, H., (1995) “Executive compensation structure, ownership, and firm performance" Journal of Financial Economics 38, 163-184.

Merton, R. (1973) "Theory of rational option pricing" Bell Journal of Economics and Management Science 4, 141-183

Meulbroek, L.K. (2001) "The efficiency of equity-linked compensation: Understanding the full cost of awarding executive stock options" Financial Management, Summer, 544. 
Milgrom, P and J. Roberts (1992) Economics, Organisation and Management, PrenticeHall, Englewood Cliffs, New Jersey

Murphy, K.J. (1985) "Corporate performance and managerial remuneration, an empirical analysis" Journal of Accounting and Economics 7, 11-42.

Murphy, K. (1999) "Executive Compensation" in Orley Ashenfelter and David Card (eds.), Handbook of Labor Economics, Vol. 3B, North-Holland, 2485-2563.

Rosen, S., (1982) "Authority, control and the distribution of earnings" Bell Journal of Economics 13, 311-323.

Ryan, H.E. (jnr) and R.A. Wiggins III (2001) "The influence of firm- and managerspecific characteristics on the structure of executive compensation" Journal of Corporate Finance 7, 101-123

Shleifer, A. and Vishny, R.W (1997) “A survey of corporate governance" Journal of Finance 52, 737-775.

Sesil, J., M. Kroumova, D. Kruse and J. Blasi (2001) "Broad-based employee stock options in the U.S.: Company performance and characteristics", working paper, Rutgers University 
Smith, C. and R. Stulz (1985) “Determinants of firms' hedging policies” Journal of Financial and Quantitative Analysis 20: 391-405

Smith, C.W. and Watts, R.L. (1982) "Incentive and tax effects of executive compensation plans" Australian Journal of Management pp 139-157.

Smith, C. and R. Watts (1992) "The investment opportunity set and corporate financing, dividend and compensation policies" Journal of Financial Economics 32, 263-292.

Stoddard, E.K. (2001) "Options in valuing equity compensation benefits" Australian Accounting Review 11 (2) 49-61

Towers Perrin (1997) to (2000) "Worldwide Total Remuneration" 